\title{
Modeling stomatal conductance in the earth system: linking leaf water-use efficiency and water transport along the soil-plant-atmosphere continuum
}

\author{
G. B. Bonan ${ }^{1}$, M. Williams ${ }^{2}$, R. A. Fisher ${ }^{1}$, and K. W. Oleson ${ }^{1}$ \\ ${ }^{1}$ National Center for Atmospheric Research, P.O. Box 3000, Boulder, Colorado, 80307, USA \\ ${ }^{2}$ School of GeoSciences, University of Edinburgh, Edinburgh, UK
}

Correspondence to: G. B. Bonan (bonan@ucar.edu)

Received: 2 April 2014 - Published in Geosci. Model Dev. Discuss.: 7 May 2014

Revised: 2 August 2014 - Accepted: 25 August 2014 - Published: 30 September 2014

\begin{abstract}
The Ball-Berry stomatal conductance model is commonly used in earth system models to simulate biotic regulation of evapotranspiration. However, the dependence of stomatal conductance $\left(g_{\mathrm{s}}\right)$ on vapor pressure deficit $\left(D_{\mathrm{s}}\right)$ and soil moisture must be empirically parameterized. We evaluated the Ball-Berry model used in the Community Land Model version 4.5 (CLM4.5) and an alternative stomatal conductance model that links leaf gas exchange, plant hydraulic constraints, and the soil-plant-atmosphere continuum (SPA). The SPA model simulates stomatal conductance numerically by (1) optimizing photosynthetic carbon gain per unit water loss while (2) constraining stomatal opening to prevent leaf water potential from dropping below a critical minimum. We evaluated two optimization algorithms: intrinsic water-use efficiency $\left(\Delta A_{\mathrm{n}} / \Delta g_{\mathrm{s}}\right.$, the marginal carbon gain of stomatal opening) and water-use efficiency $\left(\Delta A_{\mathrm{n}} / \Delta E_{1}\right.$, the marginal carbon gain of transpiration water loss). We implemented the stomatal models in a multi-layer plant canopy model to resolve profiles of gas exchange, leaf water potential, and plant hydraulics within the canopy, and evaluated the simulations using leaf analyses, eddy covariance fluxes at six forest sites, and parameter sensitivity analyses. The primary differences among stomatal models relate to soil moisture stress and vapor pressure deficit responses. Without soil moisture stress, the performance of the SPA stomatal model was comparable to or slightly better than the CLM BallBerry model in flux tower simulations, but was significantly better than the CLM Ball-Berry model when there was soil moisture stress. Functional dependence of $g_{\mathrm{s}}$ on soil moisture emerged from water flow along the soil-to-leaf pathway rather than being imposed a priori, as in the CLM Ball-Berry
\end{abstract}

model. Similar functional dependence of $g_{\mathrm{s}}$ on $D_{\mathrm{s}}$ emerged from the $\Delta A_{\mathrm{n}} / \Delta E_{1}$ optimization, but not the $\Delta A_{\mathrm{n}} / \Delta g_{\mathrm{s}}$ optimization. Two parameters (stomatal efficiency and root hydraulic conductivity) minimized errors with the SPA stomatal model. The critical stomatal efficiency for optimization ( $)$ gave results consistent with relationships between maximum $A_{\mathrm{n}}$ and $g_{\mathrm{s}}$ seen in leaf trait data sets and is related to the slope $\left(g_{1}\right)$ of the Ball-Berry model. Root hydraulic conductivity $\left(R_{\mathrm{r}}^{*}\right)$ was consistent with estimates from literature surveys. The two central concepts embodied in the SPA stomatal model, that plants account for both water-use efficiency and for hydraulic safety in regulating stomatal conductance, imply a notion of optimal plant strategies and provide testable model hypotheses, rather than empirical descriptions of plant behavior.

\section{Introduction}

The empirical Ball-Berry stomatal conductance model (Ball et al., 1987; Collatz et al., 1991) combined with the Farquhar et al. (1980) photosynthesis model was introduced into the land component of climate models in the mid-1990s (Bonan, 1995; Sellers et al., 1996; Cox et al. 1998). The stomatal conductance model is based on observations showing that for a given relative humidity $\left(h_{\mathrm{s}}\right)$, stomatal conductance $\left(g_{\mathrm{s}}\right)$ scales with the ratio of assimilation $\left(A_{\mathrm{n}}\right)$ to $\mathrm{CO}_{2}$ concentration $\left(c_{\mathrm{s}}\right)$, such that $g_{\mathrm{s}}=g_{0}+g_{1} h_{\mathrm{s}} A_{\mathrm{n}} / c_{\mathrm{s}}$. The model is now commonly used in land surface models for climate simulation. 
Part of the scientific debate about the Ball-Berry model has concerned the decline in stomatal conductance to prevent leaf desiccation with high vapor pressure deficit or low soil moisture. The Ball-Berry model uses a fractional humidity at the leaf surface, $h_{\mathrm{S}}=e_{\mathrm{S}} / e_{*}\left(T_{1}\right)=1-D_{\mathrm{S}} / e_{*}\left(T_{1}\right)$, with $e_{\mathrm{S}}$ the vapor pressure at the leaf surface, $e_{*}\left(T_{1}\right)$ the saturation vapor pressure at the leaf temperature, and $D_{\mathrm{S}}=e_{*}\left(T_{1}\right)-e_{\mathrm{S}}$ the vapor pressure deficit. Leuning (1995) modified the model to replace $h_{\mathrm{s}}$ with $\left(1+D_{\mathrm{s}} / D_{0}\right)^{-1}$, where $D_{\mathrm{s}}$ is scaled by the empirical parameter $D_{0}$. Katul et al. (2009) and Medlyn et al. (2011b) derived a dependence of $g_{\mathrm{s}}$ on $D_{\mathrm{S}}^{-1 / 2}$ based on water-use efficiency optimization. An additional challenge is how to represent stomatal closure as soil moisture declines. Various empirical functions directly impose diffusive limitations in response to soil drying by decreasing the slope parameter $\left(g_{1}\right)$ or they impose biochemical limitations and decrease $g_{\mathrm{s}}$ by reducing $A_{\mathrm{n}}$ as soil water stress increases. Neither method completely replicates observed stomatal responses to soil water stress (Egea et al., 2011; De Kauwe et al., 2013), and there is uncertainty about the form of the soil water stress function (Verhoef and Egea, 2014). Some evidence suggests that both diffusive and biochemical limitations must be considered (Zhou et al., 2013).

An alternative to the Ball-Berry model represents $g_{\mathrm{s}}$ directly from optimization theory. This theory assumes that the physiology of stomata has evolved to constrain the rate of transpiration water loss $\left(E_{1}\right)$ for a given unit of carbon gain $\left(A_{\mathrm{n}}\right)$ (Cowan, 1977; Cowan and Farquhar, 1977). This optimization can be achieved by assuming that $g_{\mathrm{s}}$ varies to maintain water-use efficiency constant over some time period (formally this means that $\partial A_{\mathrm{n}} / \partial E_{1}=$ constant; note that Cowan (1977) and Cowan and Farquhar (1977) discussed optimization in the context of the marginal water cost of carbon gain, $\left.\partial E_{1} / \partial A_{n}\right)$. The empirical Ball-Berry model, despite not being constructed explicitly as an optimality model, is consistent with this theory. Variants of the model can be derived from the Farquhar et al. (1980) photosynthesis model based on water-use efficiency optimization, after some simplifying assumptions, but the form and complexity of the stomatal model varies among Rubisco-limited (Katul et al., 2010), light-limited (Medlyn et al., 2011b), or co-limited (Vico et al., 2013) rates. For example, Medlyn et al. (2011b) obtained $g_{\mathrm{s}}=g_{0}+1.6\left(1+g_{1} D_{\mathrm{s}}^{-1 / 2}\right) A_{\mathrm{n}} / c_{\mathrm{s}}$ when photosynthesis is light-limited. However, water-use efficiency optimization does not by itself account for stomatal closure with soil moisture stress.

Additional understanding of stomatal behavior comes from the transport of water through the soil-plantatmosphere continuum, based on the principle that plants reduce stomatal conductance as needed to regulate transpiration and prevent hydraulic failure (Sperry et al., 1998, 2002). Water flows down potential gradients from the soil matrix to the leaf epidermis, maintained by water loss through the stomata. The rate of flow is proportional to the conductance of the entire soil-to-leaf path, which is a function of soil properties, plant hydraulic architecture, xylem construction, and leaf conductances. Rates of water loss from a leaf cannot, on average, exceed the rate of supply without resulting in desiccation (Meinzer, 2002). Thus, the collective architecture of the soil and plant hydraulic systems controls the maximum rate of water use, and it is widely accepted that there is a limit to the maximum rate of water transport under a given set of hydraulic circumstances. If additional suction beyond this point is applied to the continuum, rates of water supply decline, leading to desiccation in the absence of stomatal control (Sperry et al., 1998, 2002). Significant evidence has accumulated that stomatal conductance and leaf water content are strongly linked to plant and soil hydraulic architecture (Mencuccini, 2003; Choat et al., 2012; Manzoni et al., 2013).

Many models of plant hydraulic architecture exist that explicitly represent the movement of water to and from the leaf (McDowell et al., 2013). Similarly, numerical stomatal conductance models have been devised based on principles of water-use efficiency optimization and hydraulic safety (Friend, 1995; Williams et al., 1996). Despite this, efforts to account for the coupled physics and physiology of water transport along the soil-plant-atmosphere continuum in the land surface models used with earth system models have been limited.

Here, we adopted (and modified) the stomatal optimization used by the soil-plant-atmosphere model (SPA; Williams et al., 1996, 2001a), which combines both wateruse efficiency and a representation of the dynamics of leaf water potential in the same framework. The SPA model provides a numerical water-use efficiency optimization within the constraints of soil-to-leaf water flow. Stomatal conductance is calculated such that further opening does not yield a sufficient carbon gain per unit water loss (defined by the stomatal efficiency parameter $\iota$ ) or further opening causes leaf water potential to decrease below a minimum sustainable leaf water potential $\left(\psi_{1 \text { min }}\right)$. The model is therefore an optimality model with two distinct criteria (water-use efficiency and hydraulic safety).

We compared the stomatal conductance models and tested whether the performance of the alternative models can be distinguished in comparisons of model simulations with eddy covariance flux tower data. First, we tested the BallBerry stomatal conductance model used in the Community Land Model version 4.5 (CLM4.5), the land component of the Community Earth System Model. Second, we tested the original SPA parameterization, which optimizes intrinsic water-use efficiency (iWUE; $\Delta A_{\mathrm{n}} / \Delta g_{\mathrm{s}}$, the marginal carbon gain of stomatal opening). In that approach, stomatal response to $D_{\mathrm{s}}$ emerges only from stomatal closure with low leaf water potential. Third, we additionally tested the Cowan (1977) and Cowan and Farquhar (1977) wateruse efficiency optimization (WUE; $\Delta A_{\mathrm{n}} / \Delta E_{1}$, the marginal 
carbon gain of water loss) in the SPA framework. This optimization includes a direct stomatal response to $D_{\mathrm{s}}$.

\section{Methods}

We evaluated the stomatal models in a common canopy modeling framework at 6 AmeriFlux forest sites comprising a total of 51 site-years. The canopy model was forced with gapfilled tower meteorology from the North American Carbon Program (NACP) site synthesis (Schaefer et al., 2012). We compared the simulations with tower net radiation $\left(R_{\mathrm{n}}\right)$, sensible heat flux $(H)$, latent heat flux $(\lambda E)$, and gross primary production (GPP). $R_{\mathrm{n}}, H$, and $\lambda E$ were obtained from the AmeriFlux Level 2 data set. None of these fluxes were gapfilled. Gross primary production was from the NACP site synthesis (Schaefer et al., 2012). The same meteorological data and tower fluxes for these six sites were used in the development of CLM4.5 (Oleson et al., 2013).

\subsection{Flux tower sites}

The six AmeriFlux sites represented three deciduous broadleaf forests (DBF) and three evergreen needleleaf forests (ENF) spanning a range of climates (Table 1). Site descriptions were taken from published literature (Table 2):

1. US-Ha1is a mixed-species temperate deciduous forest located at Harvard Forest in central Massachusetts (Urbanski et al., 2007). The climate is temperate continental with warm summers (Köppen climate Dfb).

2. US-MMS is a mixed-species temperate deciduous forest located at the Morgan Monroe State Forest in southcentral Indiana (Schmid et al., 2000). The climate is humid subtropical (Köppen climate Cfa).

3. US-UMB is a mixed-species northern hardwood forest located at the University of Michigan Biological Station (Schmid et al., 2003). The climate is temperate continental with warm summers (Köppen climate Dfb).

4. US-Dk3 is a loblolly pine plantation located at the Duke Forest in North Carolina (Siqueira et al., 2006; Stoy et al., 2006). The climate is humid subtropical (Köppen climate Cfa). The years 2001 and 2002 had mild and severe drought, respectively.

5. US-Ho1 is a mixed-species evergreen needleleaf forest located at Howland Forest in Maine (Hollinger et al., 1999). The climate is temperate continental with warm summers (Köppen climate Dfb).

6. US-Me2 is the Metolius intermediate-aged ponderosa pine forest in central Oregon (Thomas et al., 2009). The climate is dry-summer subtropical (Köppen climate Csb). The years 2002-2003 were anomalously dry and 2006 was anomalously wet.

\subsection{Model formulation}

Many of the sites used in this study have high leaf area index $\left(>4 \mathrm{~m}^{2} \mathrm{~m}^{-2}\right)$ and highly contrasting radiative environments through the canopy. As a result, leaf assimilation, stomatal conductance, transpiration, and leaf water potential have vertical gradients within the canopy. The SPA stomatal conductance optimization is numerical and cannot be resolved arithmetically in the manner of a "big leaf" approximation that is integrated over the canopy. Therefore, we simulated the leaf water potential state and all leaf fluxes at multiple layers throughout the canopy.

We used a multi-layer canopy model (Fig. 1), similar to CANVEG (Baldocchi and Meyers, 1998; Baldocchi and Wilson, 2001; Baldocchi et al., 2002) and SPA (Williams et al., 1996, 2001a) but adapted for CLM4.5, to evaluate the stomatal models. The multi-layer model combines information about plant canopy structure, radiative transfer, leaf physiology and gas exchange, and the canopy microenvironment to simulate scalar flux exchanges with the atmosphere. It builds upon the canopy model of Bonan et al. (2011, 2012), but also utilizes the functionality of CLM4.5 (for canopy turbulence and model parameter values; Oleson et al., 2013). Within this model structure, we implemented the CLM variant of the Ball-Berry model (hereafter denoted CLM-BB) and the SPA-based stomatal models.

The canopy is divided into multiple leaf layers, each with a sunlit and shaded fraction. Radiative transfer of visible, nearinfrared, and longwave radiation is calculated at each layer, accounting for scattering within the canopy (Fig. 1a). Photosynthesis, stomatal conductance, leaf temperature, and the leaf energy balance are coupled at each layer (Fig. 1b). The CLM-BB model requires an iterative calculation of $g_{\mathrm{s}}$ and $A_{\mathrm{n}}$, because photosynthetic parameters vary with leaf temperature and leaf temperature varies with transpiration rate (Fig. 2a). The SPA stomatal optimization also uses an interactive solution to calculate $g_{\mathrm{s}}$ for each canopy layer to maximize $A_{\mathrm{n}}$ within the limitations imposed by water-use efficiency, plant water storage, and soil-to-leaf water transport (Fig. 2b). Stomatal conductance is numerically solved at each model time step (30-60 min depending on frequency of flux tower data) such that (1) further opening does not yield a sufficient carbon gain per unit water loss (defined by a stomatal efficiency parameter) or (2) further opening causes leaf water potential $\left(\psi_{1}\right)$ to decrease below a minimum value $\left(\psi_{1 \min }\right)$. Leaf water potential and water supply to foliage are calculated from a soil-plant-atmosphere continuum theory based on leaf transpiration rate $\left(E_{1}\right)$, soil water potential $\left(\psi_{\mathrm{s}}\right)$, plant capacitance $\left(C_{\mathrm{p}}\right)$, and the hydraulic conductance of the soil-to-leaf pathway $\left(k_{\mathrm{L}}\right)$. This conductance integrates in series the aboveground stem conductance $\left(k_{\mathrm{p}}\right)$ and the belowground conductance defined by a soil-to-root conductance $\left(k_{\mathrm{s}}\right)$ and a root-to-stem conductance $\left(k_{\mathrm{r}}\right)$ within each soil layer (Fig. 1c). Plant conductances are static, but the soil-toroot conductance is a function of soil hydraulic conductivity 
Table 1. Site information for the three deciduous broadleaf forest (DBF) and three evergreen needleleaf forest (ENF) flux towers, including mean annual temperature (MAT) and annual precipitation (Prec).

\begin{tabular}{llrrrrrl}
\hline Site & Forest type & Latitude & Longitude & MAT $\left({ }^{\circ} \mathrm{C}\right)$ & Prec $(\mathrm{mm})$ & Years & Frequency \\
\hline US-Ha1 & DBF & 42.54 & -72.17 & 6.6 & 1071 & $1992-2006$ & $60 \mathrm{~min}$ \\
US-MMS & DBF & 39.32 & -86.41 & 10.8 & 1032 & $1999-2006$ & $60 \mathrm{~min}$ \\
US-UMB & DBF & 45.56 & -84.71 & 5.8 & 803 & $1999-2006$ & $60 \mathrm{~min}$ \\
US-Dk3 & ENF & 35.98 & -79.09 & 14.4 & 1170 & $2000-2004$ & $30 \mathrm{~min}$ \\
US-Ho1 & ENF & 45.20 & -68.74 & 5.3 & 1070 & $1996-2004$ & $30 \mathrm{~min}$ \\
US-Me2 & ENF & 44.45 & -121.56 & 6.3 & 523 & $2002-2007$ & $30 \mathrm{~min}$ \\
\hline
\end{tabular}

Table 2. Species composition, leaf area index, canopy height, tower height, and soil texture taken from site descriptions of each flux tower.

\begin{tabular}{|c|c|c|c|c|c|}
\hline Tower & Species & $\begin{array}{l}\text { Leaf area index } \\
\qquad\left(\mathrm{m}^{2} \mathrm{~m}^{-2}\right)\end{array}$ & $\begin{array}{r}\text { Canopy } \\
\text { height }(\mathrm{m})\end{array}$ & $\begin{array}{r}\text { Tower } \\
\text { height }(\mathrm{m})\end{array}$ & $\begin{array}{r}\text { Soil } \\
\text { texture }\end{array}$ \\
\hline US-Ha1 & Red oak (Quercus rubra), red maple (Acer rubrum) & $4.5-5.5$ & 23 & 30 & Loam \\
\hline US-MMS & $\begin{array}{l}\text { Sugar maple (Acer saccharum), tulip poplar (Lirioden- } \\
\text { dron tulipifera), sassafras (Sassafras albidum), white } \\
\text { oak (Quercus alba), black oak (Quercus nigra) }\end{array}$ & 4.6 & 27 & 48 & Clay \\
\hline US-UMB & $\begin{array}{l}\text { Bigtooth aspen (Populus grandidentata) and quaking } \\
\text { aspen (Populus tremuloides), with red maple (Acer } \\
\text { rubrum), red oak (Quercus rubra), paper birch (Betula } \\
\text { papyrifera), and beech (Fagus grandifolia) }\end{array}$ & 4.2 & 21 & 46 & Sand \\
\hline US-Dk3 & Loblolly pine (Pinus taeda) & 4.2 & 19 & 22 & Sandy loam \\
\hline US-Ho1 & $\begin{array}{l}\text { Red spruce (Picea rubens), eastern hemlock (Tsuga } \\
\text { canadensis) }\end{array}$ & 5 & 20 & 29 & Sandy loam \\
\hline US-Me2 & Ponderosa pine (Pinus ponderosa) & 2.8 & 14 & 32 & Sandy loam \\
\hline
\end{tabular}

and the density of the root matrix. The full model is described in Appendix A.

The SPA model defines the critical stomatal efficiency for optimization based on intrinsic water-use efficiency $\left(l_{*}\right.$; $\left.\Delta A_{\mathrm{n}} / \Delta g_{\mathrm{s}}\right)$. An alternative stomatal efficiency is defined by water-use efficiency $\left(\iota ; \Delta A_{\mathrm{n}} / \Delta E_{1}\right)$. This latter approach follows Cowan (1977) and Cowan and Farquhar (1977), with $\iota$ the inverse of their optimization parameter lambda (based on $\partial E_{1} / \partial A_{\mathrm{n}}$, the marginal water cost of carbon gain). $\iota$ is related to $\iota_{*}$ by vapor pressure deficit $\left(\iota_{*}=\iota D_{\mathrm{S}}\right)$, as given by Eq. (A18). The model solves for $g_{\mathrm{s}}$ such that a small increment $\left(\Delta g_{\mathrm{s}}=1 \mathrm{mmol} \mathrm{H}_{2} \mathrm{O} \mathrm{m}^{-2} \mathrm{~s}^{-1}\right)$ changes leaf assimilation by $\Delta A_{\mathrm{n}} \leq \iota_{*} \Delta g_{\mathrm{s}}$ (iWUE optimization) or $\Delta A_{\mathrm{n}} \leq$ $\iota D_{\mathrm{s}} \Delta g_{\mathrm{s}}$ (WUE optimization) with the constraint that $\psi_{1}>$ $\psi_{1 \mathrm{~min}}$. We tested both optimizations, designated SPA-iWUE and SPA-WUE, respectively.

\subsection{Model parameters}

Table 3 lists parameters specified by plant functional type, and Table 4 lists site-specific parameters. Plant functional type parameters are from CLM4.5, except for the SPA stomatal model. A key parameter is the maximum carboxylation rate at $25^{\circ} \mathrm{C}\left(V_{\mathrm{c} \max 25}\right)$. We used values from Kattge et al. (2009), also used in the simulations of Bonan et al. $(2011,2012)$, which are generally consistent with site-specific estimates calculated from observed foliage nitrogen (Table 5). The largest deviation is for US-UMB and US-Me2, where the model $V_{\mathrm{cmax} 25}$ is larger than the observationally based estimate. Values for additional photosynthetic metabolic parameters $\left(J_{\max 25}\right.$ and $\left.R_{\mathrm{d} 25}\right)$ are proportional to $V_{\mathrm{c} \max 25}$. The SPA stomatal optimization requires four additional physiological parameters that describe plant water relations $\left(\psi_{\operatorname{lmin}}, C_{\mathrm{p}}, k_{\mathrm{p}}\right.$, and $\left.\iota\right)$ and four parameters for fine roots needed to calculate the belowground conductance $\left(M_{T}\right.$, $r_{\mathrm{r}}, r_{\mathrm{d}}$, and $R_{\mathrm{r}}^{*}$ ).

\subsubsection{Minimum leaf water potential}

Values of $\psi_{1 \min }$ vary greatly among plant types, particularly in arid environments (Choat et al., 2012). We used $\psi_{1 \min }=$ $-2 \mathrm{MPa}$, which reflects values typically found in closed forest canopies. This is similar to values used in previous SPA simulations for arctic ecosystems and black spruce boreal forest ( $-1.5 \mathrm{MPa}$; Williams et al., 2000; Hill et al., 2011), ponderosa pine ( -1.7 to $-2.0 \mathrm{MPa}$; Williams et al., 2001a, b; Schwarz et al., 2004), deciduous forest ( $-2.5 \mathrm{MPa}$; Williams et al., 1996), tropical rainforest $(-2.5 \mathrm{MPa}$; Williams et al., 1998; Fisher et al., 2007), and Australian woodland $(-2.8 \mathrm{MPa}$; Zeppel et al., 2008). 
(a) Radiative transfer
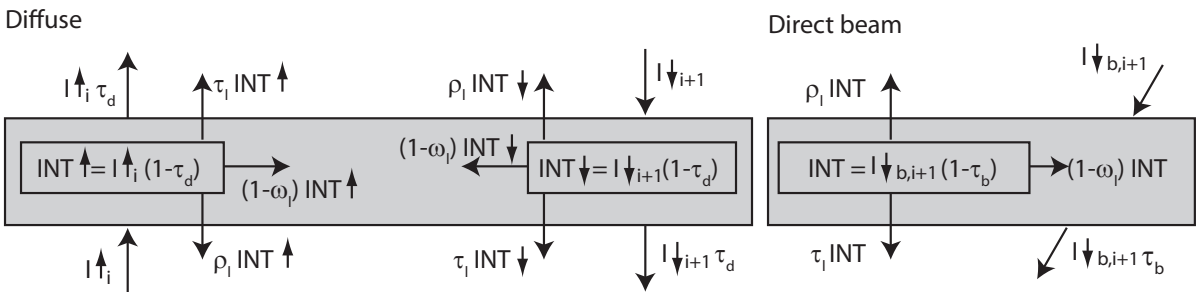

(b) Leaf fluxes

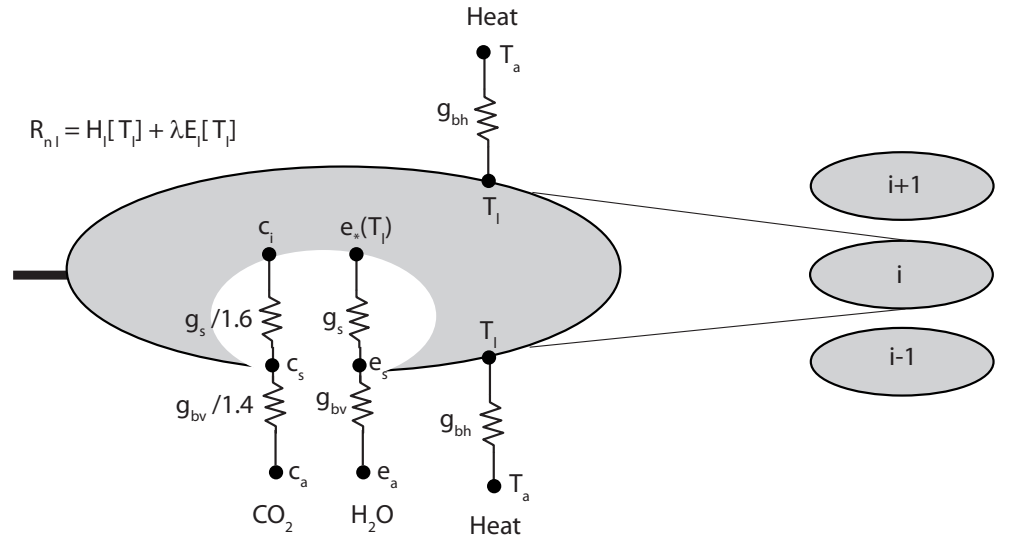

(c) Plant hydraulics

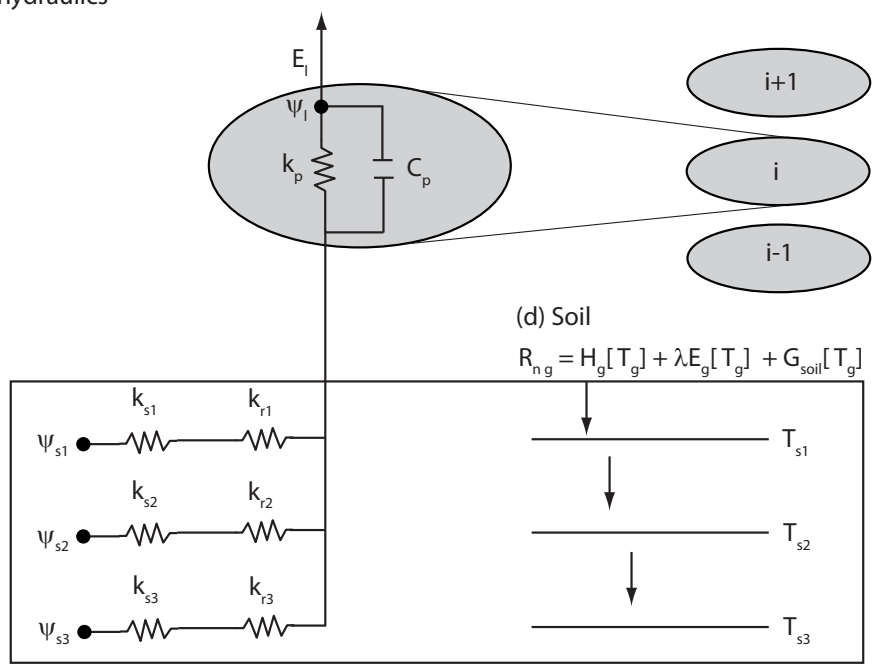

Figure 1. Overview of the main processes in the canopy model. The canopy is represented by $n$ leaf layers with layer $i+1$ above layer $i$. (a) Diffuse and direct solar radiation for layer $i+1$. Diffuse radiation passes through the layer, proportional to $\tau_{\mathrm{d}}$. The intercepted fraction $\left(1-\tau_{\mathrm{d}}\right)$ is scattered forward $\left(\tau_{1}\right)$, scattered backward $\left(\rho_{1}\right)$, or absorbed $\left(1-\omega_{1} ; \omega_{1}=\tau_{1}+\rho_{1}\right)$. The intercepted direct beam $\left(1-\tau_{\mathrm{b}}\right)$ is similarly absorbed or scattered. Longwave radiation is similar to diffuse radiation, with $\omega_{1}=1-\varepsilon_{1}$ and the intercepted longwave radiation is reflected $\left(\rho_{1}=\omega_{1}, \tau_{1}=0\right)$. (b) Leaf sensible heat, transpiration, and $\mathrm{CO}_{2}$ fluxes. Leaf temperature $\left(T_{1}\right)$ is the temperature that balances the energy budget. Sensible heat is exchanged from both sides of the leaf, proportional to the leaf boundary layer conductance $\left(g_{\text {bh }}\right)$ and the temperature gradient with air $\left(T_{1}-T_{\mathrm{a}}\right)$. Water vapor is lost from the stomatal cavity to air, proportional to the vapor pressure deficit $\left(e_{*}\left(T_{1}\right)-e_{\mathrm{a}}\right)$ and stomatal $\left(g_{\mathrm{s}}\right)$ and boundary layer $\left(g_{\mathrm{bv}}\right)$ conductances in series. $\mathrm{CO}_{2}$ similarly diffuses from the canopy air into the stomata, proportional to the gradient $c_{\mathrm{a}}-c_{i}$. (c) Soil water uptake by a canopy layer. Each canopy layer has an aboveground plant stem conductance $\left(k_{\mathrm{p}}\right)$ and a capacitance $\left(C_{\mathrm{p}}\right)$. Multiple root layers occur in parallel with a conductance comprised of soil $\left(k_{\mathrm{s}}\right)$ and root $\left(k_{\mathrm{r}}\right)$ components in series. The soil conductance varies with soil water potential $\left(\psi_{\mathrm{s}}\right)$. (d) Soil energy balance and heat flow. Sensible heat, latent heat, and soil heat fluxes depend on ground temperature $\left(T_{\mathrm{g}}\right)$. The soil heat flux is transferred within the soil profile using a Crank-Nicolson formulation with soil heat flux as the upper boundary condition and soil heat capacity and thermal conductivity specified from soil texture, mineralogical properties, and soil water. Appendix A provides the full equation set. 
(a) Ball-Berry stomata

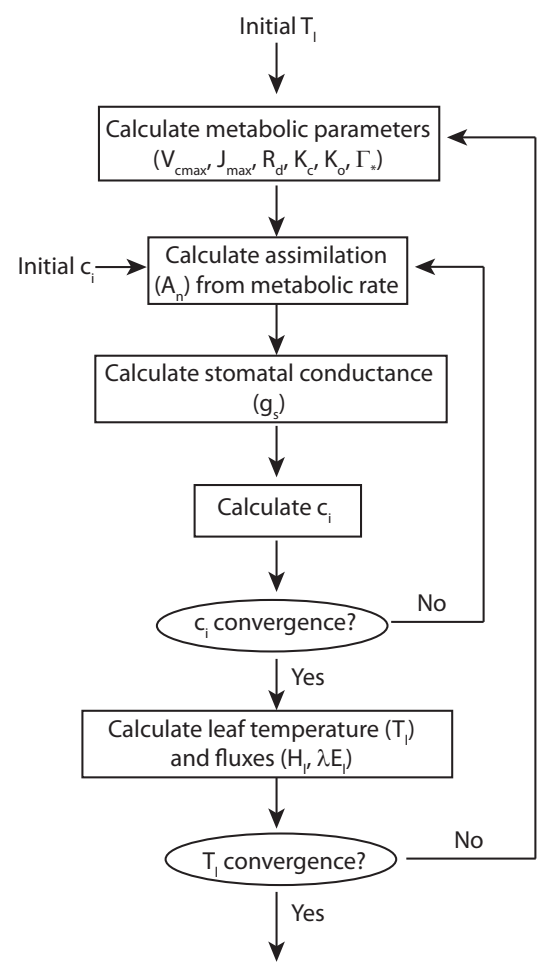

(b) Numerical stomata optimization

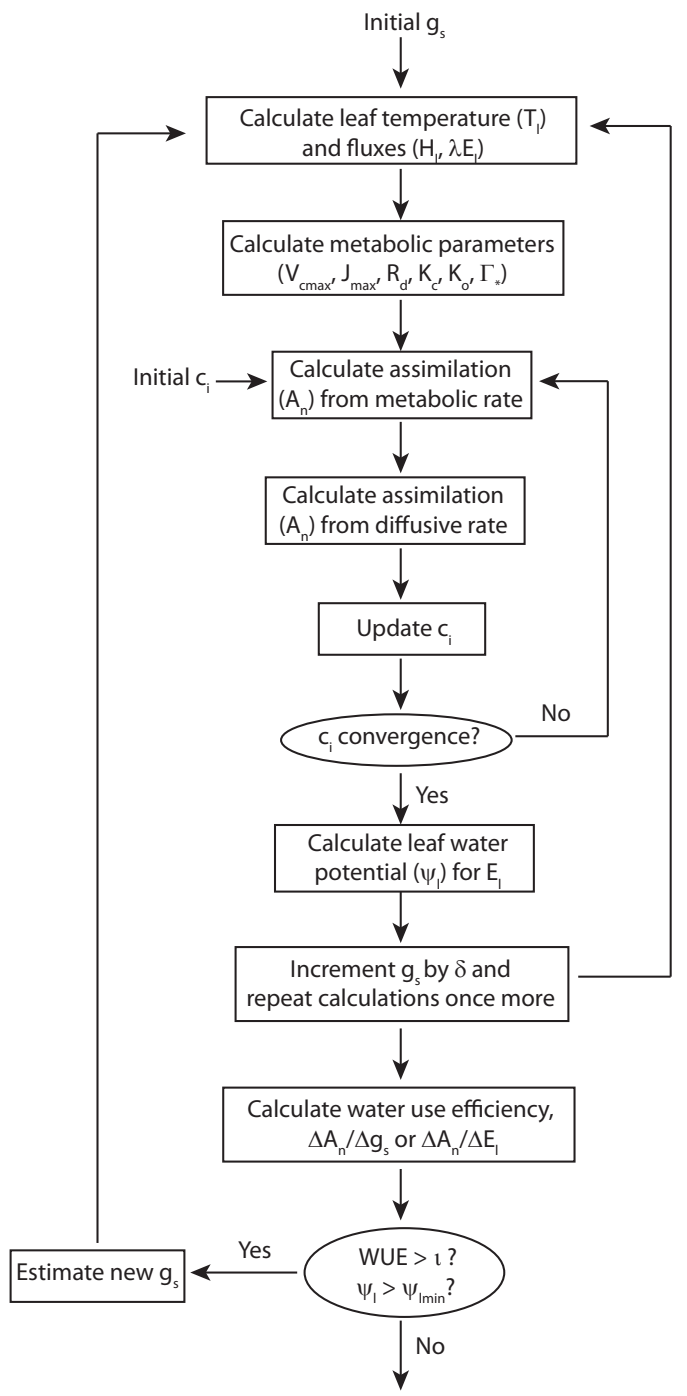

Figure 2. Flow diagram of leaf flux calculations using (a) the Ball-Berry model and (b) the SPA stomatal optimization. In both approaches, numerical methods are used to efficiently solve for $g_{\mathrm{s}}$. The SPA optimization is shown for water-use efficiency $\left(\Delta A_{\mathrm{n}} / \Delta E_{1}\right)$. The same approach is used for intrinsic water-use efficiency $\left(\Delta A_{\mathrm{n}} / \Delta g_{\mathrm{s}}\right)$.

\subsubsection{Plant capacitance}

Plant capacitance controls the timing of water use throughout the day. High values mean that there is a large buffer (storage) at the beginning of the day, before (in dry soils) water use is ultimately limited to the rate of supply directly from the soil. We used $C_{\mathrm{p}}=2500 \mathrm{mmol} \mathrm{H}_{2} \mathrm{O} \mathrm{m}^{-2}$ leaf area $\mathrm{MPa}^{-1}$. Previous SPA simulations used a range of values for black spruce boreal forest (2000; Hill et al., 2011), tropical rainforest (2300; Fisher et al., 2007; derived from Goldstein et al., 1998), Australian woodland (5000; Zeppel et al., 2008), and deciduous and tropical forest (8000; Williams et al., 1996, 1998).

\subsubsection{Plant hydraulic conductance}

The SPA model assumes a constant plant conductance to water. This is a simplification compared to more complex models that diagnose changes in conductance caused by xylem embolism under tension (Sperry et al., 2002; McDowell et al., 2013). However, previous analyses suggest that the majority of soil-to-leaf resistance is belowground (Fisher et al., 2007) and also that the soil-to-root resistance provides an adequate explanation of the variability in observed soil-to-leaf resistance (Williams et al., 2001a; Zeppel et al., 2008). Previous SPA simulations used stem hydraulic conductivity (not conductance) with a range of values of 3.5$100 \mathrm{mmol} \mathrm{H}_{2} \mathrm{O} \mathrm{m}^{-1} \mathrm{~s}^{-1} \mathrm{MPa}^{-1}$ (Williams et al., 1996, 1998, 
Table 3. Model parameter values for evergreen needleleaf forest (ENF) and deciduous broadleaf forest (DBF) plant functional types. Parameter values are from CLM4.5 (Oleson et al., 2013), except for the stomatal optimization (as described in the text).

\begin{tabular}{|c|c|c|c|c|}
\hline Symbol & Description & Units & ENF & DBF \\
\hline$V_{\mathrm{c} \max 25}$ & Maximum carboxylation rate at $25^{\circ} \mathrm{C}$ & $\mu \mathrm{mol} \mathrm{m}{ }^{-2} \mathrm{~s}^{-1}$ & 62.5 & 57.7 \\
\hline$\rho_{1}$ & Leaf reflectance (vis, nir) & - & $0.07,0.35$ & $0.10,0.45$ \\
\hline$\tau_{1}$ & Leaf transmittance (vis, nir) & - & $0.05,0.10$ & $0.05,0.25$ \\
\hline$\chi_{1}$ & $\begin{array}{l}\text { Departure of leaf angle from spherical orienta- } \\
\text { tion }\end{array}$ & - & 0.01 & 0.25 \\
\hline$\varepsilon_{1}$ & Leaf emissivity & - & 0.98 & 0.98 \\
\hline$d_{1}$ & Leaf dimension & $\mathrm{m}$ & 0.04 & 0.04 \\
\hline$r_{\mathrm{a}}$ & CLM4.5 rooting distribution parameter & $\mathrm{m}^{-1}$ & 7 & 6 \\
\hline$r_{\mathrm{b}}$ & $\begin{array}{l}\text { CLM } 4.5 \text { rooting distribution parameter } \\
\text { Ball-Berry }\end{array}$ & $\mathrm{m}^{-1}$ & 2 & 2 \\
\hline$g_{0}$ & Minimum leaf conductance & $\mathrm{mol} \mathrm{H}_{2} \mathrm{Om}^{-2} \mathrm{~s}^{-1}$ & 0.01 & 0.01 \\
\hline$g_{1}$ & Slope parameter & - & 9 & 9 \\
\hline$\psi_{\mathrm{c}}$ & Soil water potential for stomatal closure & $\mathrm{mm}$ & -255000 & -224000 \\
\hline$\psi_{\mathrm{o}}$ & $\begin{array}{l}\text { Soil water potential at which stomata are fully } \\
\text { open } \\
\text { SPA optimization }\end{array}$ & $\mathrm{mm}$ & -66000 & -35000 \\
\hline$\psi_{1 \min }$ & Minimum leaf water potential & $\mathrm{MPa}$ & -2 & -2 \\
\hline$k_{\mathrm{p}}$ & Leaf-specific stem hydraulic conductance & $\mathrm{mmol} \mathrm{H}_{2} \mathrm{O} \mathrm{m}^{-2}$ leaf area s ${ }^{-1} \mathrm{MPa}^{-1}$ & 4 & 4 \\
\hline$C_{\mathrm{p}}$ & Plant capacitance & $\mathrm{mmol} \mathrm{H}_{2} \mathrm{O} \mathrm{m}^{-2}$ leaf area $\mathrm{MPa}^{-1}$ & 2500 & 2500 \\
\hline$\iota *, \iota$ & $\begin{array}{l}\text { Stomatal efficiency } \\
\left(\Delta A_{\mathrm{n}} / \Delta g_{\mathrm{s}}, \Delta A_{\mathrm{n}} / \Delta E_{1}\right)\end{array}$ & $\mu \mathrm{mol} \mathrm{CO} 2 \mathrm{~mol}^{-1} \mathrm{H}_{2} \mathrm{O}$ & $15,1500^{\mathrm{a}}$ & $7.5,750$ \\
\hline$M_{T}$ & Fine root biomass & $\mathrm{g} \mathrm{m}^{-2}$ & 500 & 500 \\
\hline$r_{\mathrm{r}}$ & Fine root radius & $\mathrm{m}$ & $0.29 \times 10^{-3}$ & $0.29 \times 10^{-3}$ \\
\hline$r_{\mathrm{d}}$ & Specific root density (fine root) & $\mathrm{g}$ biomass $\mathrm{m}^{-3}$ root & $0.31 \times 10^{6}$ & $0.31 \times 10^{6}$ \\
\hline$R_{\mathrm{r}}^{*}$ & Fine root hydraulic resistivity & MPa s g mmol ${ }^{-1} \mathrm{H}_{2} \mathrm{O}$ & $25^{\mathrm{b}}$ & 25 \\
\hline
\end{tabular}

${ }^{\mathrm{a}}$ Except for US-Dk3, which used the DBF values. We also tested the lower values used for DBF. ${ }^{\mathrm{b}}$ We also tested a value of 75 for ENF.

Table 4. Site-specific model input. The model additionally uses the canopy height, plant functional type, and soil texture at each tower site.

\begin{tabular}{llll}
\hline Symbol & Description & Units & Source \\
\hline$z_{\text {ref }}$ & Tower reference height & $\mathrm{m}$ & Tower \\
$T_{\text {ref }}$ & Air temperature & $\mathrm{K}$ & Tower \\
$e_{\text {ref }}$ & Vapor pressure & $\mathrm{Pa}$ & Tower \\
$u_{\text {ref }}$ & Wind speed & $\mathrm{m} \mathrm{s}^{-1}$ & Tower \\
$c_{\text {ref }}$ & $\mathrm{CO}_{2}$ concentration & $\mu \mathrm{mol} \mathrm{mol}^{-1}$ & CLM4.5 \\
$P_{\text {ref }}$ & Air pressure & $\mathrm{Pa}$ & Tower \\
$S \downarrow$ & Solar radiation & $\mathrm{W} \mathrm{m}^{-2}$ & Tower \\
$f_{\text {dif }}$ & Diffuse fraction & - & CLM4.5 \\
$Z$ & Solar zenith angle & - & CLM4.5 \\
$L \downarrow$ & Longwave radiation & $\mathrm{W} \mathrm{m}^{-2}$ & Tower \\
$\beta_{t}$ & Soil wetness factor & - & CLM4.5 \\
$\theta_{j}$ & Volumetric soil water & $\mathrm{m}^{3} \mathrm{~m}^{-3}$ & CLM4.5 \\
$L_{T}$ & Leaf area index & $\mathrm{m}^{2} \mathrm{~m}^{-2}$ & CLM4.5 \\
\hline
\end{tabular}

2001a, b; Schwarz et al., 2004; Zeppel et al., 2008; Hill et al., 2011). In contrast, we used a leaf-specific stem hydraulic conductance $k_{\mathrm{p}}=4 \mathrm{mmol} \mathrm{H}_{2} \mathrm{O} \mathrm{m}^{-2}$ leaf area s ${ }^{-1} \mathrm{MPa}^{-1}$, estimated from stem, root, and whole-plant conductance reported in the literature as follows below.

Our value for $k_{\mathrm{p}}$ is consistent with observational estimates of stem conductance. Yang and Tyree (1994) reported leaf-specific stem conductance values of 1.4 $2.8 \mathrm{mmol} \mathrm{H}_{2} \mathrm{O} \mathrm{m}^{-2} \mathrm{~s}^{-1} \mathrm{MPa}^{-1}$ for large maple trees (Acer saccharum, Acer rubrum). Tyree et al. (1998) reported $1-4 \mathrm{mmol} \mathrm{H}_{2} \mathrm{O} \mathrm{m}^{-2} \mathrm{~s}^{-1} \mathrm{MPa}^{-1}$ for tropical tree seedlings. Tyree et al. (1993) found a value of $7 \mathrm{mmol} \mathrm{H}_{2} \mathrm{O} \mathrm{m}^{-2} \mathrm{~s}^{-1} \mathrm{MPa}^{-1}$ for walnut (Juglans regia) saplings.

Our estimate of leaf-specific stem conductance $\left(k_{\mathrm{p}}\right)$ gives a leaf-specific whole-plant (soil-to-leaf) conductance $\left(k_{\mathrm{L}}\right)$ that is consistent with field estimates. A stem conductance $k_{\mathrm{p}}=4 \mathrm{mmol} \mathrm{H}_{2} \mathrm{O} \mathrm{m}^{-2} \mathrm{~s}^{-1} \mathrm{MPa}^{-1}$ gives a whole-plant conductance $k_{\mathrm{L}}=2 \mathrm{mmol} \mathrm{H}_{2} \mathrm{O} \mathrm{m}^{-2} \mathrm{~s}^{-1} \mathrm{MPa}^{-1}$ for moist soil with neglibile soil resistance, if root and stem conductances are equal. Duursma and Medlyn (2012) used this value for $k_{\mathrm{L}}$ in the MAESPA model. Various estimates of $k_{\mathrm{L}}$ reported in the literature are $1.1 \mathrm{mmol} \mathrm{H}_{2} \mathrm{O} \mathrm{m}^{-2} \mathrm{~s}^{-1} \mathrm{MPa}^{-1}$ for loblolly 
Table 5. Site vegetation parameters used in the model simulations.

\begin{tabular}{|c|c|c|c|c|c|}
\hline \multirow[b]{2}{*}{ Site } & \multirow[b]{2}{*}{ Foliage $\mathrm{N}$ (\% by mass) } & \multicolumn{2}{|c|}{$V_{\mathrm{cmax} 25}$} & \multicolumn{2}{|c|}{ Leaf area index (LAI) } \\
\hline & & Observed $^{\mathrm{c}}$ & CLM $4.5^{\mathrm{d}}$ & Observed & CLM4.5 \\
\hline \multirow[t]{2}{*}{ US-Ha1 } & $1.97^{\mathrm{a}}$ & 50.4 & 57.7 & $5.1^{\mathrm{a}}$ & 4.9 \\
\hline & $1.95^{\mathrm{b}}$ & 49.9 & & $4.9^{b}$ & \\
\hline \multirow[t]{2}{*}{ US-MMS } & $2.22^{\mathrm{a}}$ & 56.0 & 57.7 & $4.6^{\mathrm{a}}$ & 4.7 \\
\hline & $2.06^{\mathrm{b}}$ & 52.4 & & $4.9^{b}$ & \\
\hline US-UMB & $1.76^{\mathrm{a}}$ & 45.6 & 57.7 & $4.2^{\mathrm{a}}$ & 4.2 \\
\hline \multirow[t]{2}{*}{ US-Dk3 } & $1.19^{\mathrm{a}}$ & 59.9 & 62.5 & $4.2^{\mathrm{a}}$ & 4.7 \\
\hline & $1.47^{\mathrm{b}}$ & 72.5 & & $4.5^{b}$ & \\
\hline \multirow[t]{2}{*}{ US-Ho1 } & $1.06^{\mathrm{a}}$ & 54.0 & 62.5 & $5.2^{\mathrm{a}}$ & 4.6 \\
\hline & $1.16^{\mathrm{b}}$ & 58.5 & & $5.7^{\mathrm{b}}$ & \\
\hline US-Me2 & $0.93^{\mathrm{a}}$ & 48.2 & 62.5 & $2.8^{\mathrm{a}}$ & 3.8 \\
\hline
\end{tabular}

a Observations from AmeriFlux Level 2 biological, ancillary, disturbance and metadata. ${ }^{\mathrm{b}}$ Observations from Ollinger et al. (2008). ${ }^{c}$ Estimated using empirical relationships between $\mathrm{N}_{\text {area }}$ and $V_{\mathrm{cmax} 25}$ from the TRY leaf trait database (Kattge et al., 2009) with observed foliage $\mathrm{N}$ converted from $\mathrm{N}_{\text {mass }}$ to $\mathrm{N}_{\text {area }}$ using the mean leaf mass per unit area (LMA) for temperate forest trees reported in the Glopnet leaf trait database (Wright et al., 2004). DBF, $n=191, \mathrm{LMA}=76 \mathrm{~g} \mathrm{~m}^{-2}$. ENF, $n=18$, LMA $=248 \mathrm{~g} \mathrm{~m}^{-2}$. ${ }^{\mathrm{d}}$ Oleson et al. (2013), using the mean values of Kattge et al. (2009).

pine (Pinus taeda) in North Carolina (Ewers et al., 2000); on the order of $0.5-1$ for aspen (Populus tremuloides) and black spruce (Picea mariana) and 6-11 for jack pine (Pinus banksiana) boreal forest in Manitoba, Canada (Ewers et al., 2005); 1-10 for tropical trees (Meinzer et al., 1995); and 6 for Betula occidentalis in the field (Saliendra et al., 1995). Few studies report the root portion of whole-plant conductance. Studies of walnut (Tyree et al., 1994) and tropical tree seedlings (Tyree et al., 1998) found approximately equal root and stem conductances. Federer et al. (2003) assumed equal root and stem conductances in their model.

\subsubsection{Stomatal efficiency}

The stomatal efficiency parameter defines the water-use strategy (Williams et al., 1996). Low values, with a low marginal carbon gain, optimize at high $A_{\mathrm{n}}$, high $g_{\mathrm{s}}$, and high $E_{1}$; consequently, plant water storage can be depleted, causing stomata to close in early-afternoon. Higher values, with a larger marginal return, describe a more conservative strategy. Optimization is achieved at lower $g_{\mathrm{s}}$, so that $A_{\mathrm{n}}$ and $E_{1}$ are also lower. This reduces afternoon water stress, but restricts daily GPP.

We tested two alternative definitions of stomatal efficiency: $\iota_{*}$, based on intrinsic water-use efficiency $\left(\Delta A_{\mathrm{n}} / \Delta g_{\mathrm{s}}\right)$, as used in SPA (Williams et al., 1996); and $\iota$, based on water-use efficiency $\left(\Delta A_{\mathrm{n}} / \Delta E_{1}\right)$. Our baseline values are $\iota_{*}=7.5$ and $\iota=750 \mu \mathrm{mol} \mathrm{CO}_{2} \mathrm{~mol}^{-1} \mathrm{H}_{2} \mathrm{O}$. These values give maximum $A_{\mathrm{n}}$ and $g_{\mathrm{s}}$ that are consistent with observations from the Glopnet leaf trait database (Wright et al., 2004) and that minimize root mean square error in canopy-scale simulations. For evergreen needleleaf forest, we also tested a more conservative water-use strategy, $\iota_{*}=15$ and $\iota=1500 \mu \mathrm{mol} \mathrm{CO}_{2} \mathrm{~mol}^{-1} \mathrm{H}_{2} \mathrm{O}$.

\subsubsection{Root conductance}

To calculate the hydraulic conductivity of the soil-to-root pathway $\left(k_{\mathrm{S}}\right)$, SPA requires root length density as a vertical profile. In the absence of direct measurements, the model uses fine root biomass $\left(M_{T}\right)$, average fine root radius $\left(r_{\mathrm{r}}\right)$, and specific root density $\left(r_{\mathrm{d}}\right)$ as inputs. We obtained these for fine roots $(\leq 2 \mathrm{~mm}$ diameter) from Jackson et al. (1997). Live fine root biomass in temperate deciduous and coniferous forests averages 440 and $500 \mathrm{~g} \mathrm{~m}^{-2}$, respectively. We used $M_{T}=500 \mathrm{~g} \mathrm{~m}^{-2}$. This is comparable to values of $400-1000 \mathrm{~g} \mathrm{~m}^{-2}$ used in previous SPA simulations (Williams et al., 2001a; Schwarz et al., 2004; Fisher et al., 2007; Hill et al., 2011). The mean fine root radius of trees is $r_{\mathrm{r}}=0.29 \mathrm{~mm}$ and the specific root length is $12.2 \mathrm{~m} \mathrm{~g}^{-1}$, so that the specific root density is $r_{\mathrm{d}}^{-1}=12.2 \mathrm{~m} \mathrm{~g}^{-1} \times \pi r_{\mathrm{r}}^{2}$ and $r_{\mathrm{d}}=0.31 \mathrm{~g} \mathrm{~cm}^{-3}$. Williams et al. (2001a) used $r_{\mathrm{r}}=0.50 \mathrm{~mm}$ and $r_{\mathrm{d}}=0.50 \mathrm{~g} \mathrm{~cm}^{-3}$ in ponderosa pine simulations.

The root-to-stem conductance $\left(k_{\mathrm{r}}\right)$ requires a root hydraulic resistivity $\left(R_{\mathrm{r}}^{*}\right)$. We used $R_{\mathrm{r}}^{*}=$ $25 \mathrm{MPa} \mathrm{s} \mathrm{g} \mathrm{mol}^{-1} \mathrm{H}_{2} \mathrm{O}$. Shimizu et al. (2005) reported root hydraulic resistivity values $<5 \mathrm{MPasg} \mathrm{mmol}^{-1}$ for saplings of six tropical tree species. Tyree et al. (1998) reported values of 5-36 MPas g mmol ${ }^{-1}$ for seedlings of five tropical tree species. Rieger and Litvin (1999) reported that root hydraulic conductivity (per unit length) of several woody plant species ranges from about 0.55$5.5 \times 10^{-3} \mathrm{mmol} \mathrm{m}^{-1} \mathrm{~s}^{-1} \mathrm{MPa}^{-1}$; this is equivalent to a resistivity of $15-150 \mathrm{MPas} \mathrm{mmol}^{-1}$ with a specific root length of $12.2 \mathrm{~m} \mathrm{~g}^{-1}$. Other SPA simulations used values of 3-400 MPa s $\mathrm{mmol}^{-1}$ (Williams et al., 2001a, b; Schwarz et al., 2004; Zeppel et al., 2008). With fine root biomass $M_{T}=500 \mathrm{~g} \mathrm{~m}^{-2}, R_{\mathrm{r}}^{*}=25 \mathrm{MPasg} \mathrm{mmol}^{-1}$ gives a total root conductance of $20 \mathrm{mmol} \mathrm{m}^{-2}$ ground area s${ }^{-1} \mathrm{MPa}^{-1}$, 
or $4 \mathrm{mmol} \mathrm{m}^{-2}$ leaf area s${ }^{-1} \mathrm{MPa}^{-1}$ in a forest with a leaf area index of $5 \mathrm{~m}^{2} \mathrm{~m}^{-2}$. For evergreen needleleaf forest, we additionally tested $R_{\mathrm{r}}^{*}=75 \mathrm{MPa} \mathrm{s} \mathrm{mmol}^{-1}$, obtained from parameter optimization analysis.

\subsection{Model simulations and evaluation}

\subsubsection{Canopy-scale simulations}

We used meteorological observations at the flux tower sites to drive the canopy model and eddy covariance observations from those same towers to evaluate the model. The gap-filled tower meteorology was available at either 30 or $60 \mathrm{~min}$ frequency depending on site (Table 4). Similar simulations were performed to evaluate CLM4.5. Those simulations specified $\mathrm{CO}_{2}$ concentration at $367 \mu \mathrm{mol} \mathrm{mol}^{-1}$, which we also used to allow model comparison. We only used data for the month of July to evaluate the simulations, to constrain the model without seasonal changes in leaf area or soil water. Our intent was to use the SPA stomatal conductance model to inform deficiencies in the performance of the CLM4.5 canopy flux parameterization given specified soil water. Soil temperature was initialized from a spin-up simulation that repeated the July forcing data. Soil moisture inputs were obtained from CLM4.5 simulations for the tower sites, with the same forcing. The canopy model additionally used the tower height, canopy height, plant functional type, leaf area index, and soil texture at each tower site.

Vegetation and soil parameters were from CLM4.5, based on the vegetation and soil texture of each tower site (Oleson et al., 2013). A single plant functional type (broadleaf deciduous tree or needleleaf evergreen tree) was used for each site. Canopy top height $\left(h_{\text {top }}\right)$ was specified from the tower canopy height, and the bottom height $\left(h_{\text {bot }}\right)$ was obtained using the CLM4.5 ratio of top and bottom heights (evergreen needleleaf tree, $17 / 8.5 \mathrm{~m}$; deciduous broadleaf tree, $20 / 11.5 \mathrm{~m})$. Roughness length $\left(z_{0}\right)$ and displacement height $(d)$ were specified in proportion to canopy height as in CLM4.5 $\left(z_{0}=0.055 h_{\text {top }}\right.$ and $\left.d=0.67 h_{\text {top }}\right)$. We used the same leaf area index as in CLM4.5 for the flux tower sites (Table 5). Those values, obtained from high-resolution CLM4.5 surface data sets, are comparable to values reported for July in site syntheses (Table 2) as well as the AmeriFlux Level 2 data set and Ollinger et al. (2008). The $V_{\mathrm{cmax} 25}$ values are comparable to values estimated from observed foliage nitrogen at each site (Table 5). The largest discrepancy is for US-Me2, where leaf area index is $36 \%$ too high and $V_{\mathrm{cmax} 25}$ is $30 \%$ too high.

We evaluated the canopy model using flux tower estimates of $R_{\mathrm{n}}, H, \lambda E$, and GPP. Flux measurement errors arise from systematic bias and random errors (Richardson et al., 2012). We did not correct the data for systematic errors due to failure in energy balance closure. Other model-data comparisons have forced energy balance closure (e.g., Stöckli et al., 2008), but the reasons for lack of closure are still being
Table 6. Standard deviation of the random flux error, $\sigma(\varepsilon)$, for forests. $\sigma(\varepsilon)$ scales with the magnitude of the flux (Richardson et al., 2006, 2012).

\begin{tabular}{lll}
\hline & \multicolumn{2}{c}{$\sigma(\varepsilon)$} \\
\cline { 2 - 3 } Flux & Flux $\geq 0$ & Flux $\leq 0$ \\
\hline$H$ & $19.7+0.16 H$ & $10.0-0.44 H$ \\
$\lambda E$ & $15.3+0.23 \lambda E$ & $6.2-1.42 \lambda E$ \\
\hline
\end{tabular}

debated and include methodological concerns, failure to account for storage terms, and landscape heterogeneity (Foken, 2008; Hendricks Franssen et al., 2010; Leuning et al., 2012; Stoy et al., 2013). Random errors in flux measurements occur because of sampling errors, errors in the instrument system, and other factors and can be large (Richardson et al., 2012). We estimated random errors using the empirical relationships of Richardson et al. (2006, 2012). The probability distribution of random flux errors is described by a doubleexponential, or Laplace, distribution. About $76 \%$ of the values drawn from a double-exponential distribution fall within \pm 1 standard deviation of the mean and $94 \%$ fall within \pm 2 standard deviations. Richardson et al. $(2006,2012)$ showed that the standard deviation of the random error, $\sigma(\varepsilon)$, scales with the magnitude of the flux (Table 6).

For each of the 51 site-years, we performed simulations with baseline parameter values (Table 3). The SPA model calculates stomatal conductance using both stomatal efficiency $(\iota)$ and hydraulic safety $\left(\psi_{1}>\psi_{1 \text { min }}\right)$ as the optimization criteria. We repeated the flux tower simulations without the hydraulic safety constraint to isolate which physiological process is most important. In these simulations, stomatal conductance is only regulated by the stomatal efficiency parameter.

We additionally performed three sets of parameter sensitivity analyses to assess parameter optimization for the CLM-BB model and the SPA-WUE optimization model. (1) For the CLM-BB model, we simultaneously varied the intercept $g_{0}\left(0.001-0.1 \mathrm{~mol} \mathrm{H}_{2} \mathrm{O} \mathrm{m}^{-2} \mathrm{~s}^{-1}\right)$ and the slope parameter $g_{1}$ (3-15). (2) For the SPAWUE model, we simultaneously varied four plant parameters that affect aboveground plant hydraulics: $\psi_{1 \min }$ (-2 to $-4 \mathrm{MPa}), k_{\mathrm{p}}\left(1-20 \mathrm{mmol} \mathrm{H}_{2} \mathrm{O} \mathrm{m}^{-2} \mathrm{~s}^{-1} \mathrm{MPa}^{-1}\right.$ ), $C_{\mathrm{p}} \quad\left(1000-10000 \mathrm{mmol} \mathrm{H}_{2} \mathrm{O} \mathrm{m}^{-2} \mathrm{MPa}^{-1}\right)$, and $\iota$ (500$1500 \mu \mathrm{mol} \mathrm{CO}_{2} \mathrm{~mol}^{-1} \mathrm{H}_{2} \mathrm{O}$ ). (3) In a separate set of simulations with the SPA-WUE model, we simultaneously varied four plant parameters that govern belowground root conductance: $M_{T}\left(400-1000 \mathrm{~g} \mathrm{~m}^{-2}\right), r_{\mathrm{r}}(0.1-0.5 \mathrm{~mm}), r_{\mathrm{d}}(200$ $\left.500 \mathrm{~kg} \mathrm{~m}^{-3}\right)$, and $R_{\mathrm{r}}^{*}\left(10-500 \mathrm{MPa} \mathrm{s} \mathrm{mmol}^{-1} \mathrm{H}_{2} \mathrm{O}\right)$. The range of parameter values reflects the range of values reported in literature and previous modeling studies. We used latin hypercube sampling to generate a collection of random parameter values with a sample size of $m=500$ points with $n=2$ (CLM-BB) or $n=4$ (SPA-WUE) variables. 

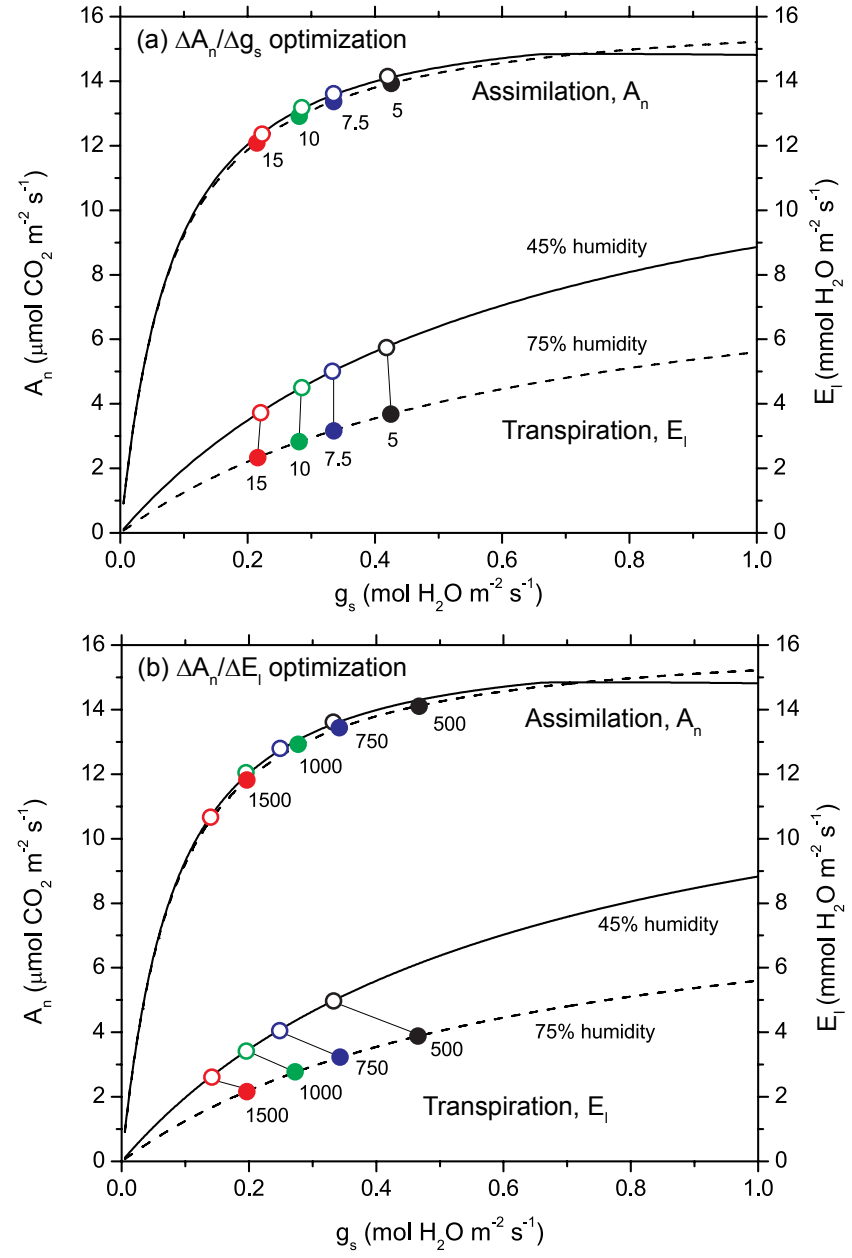

Figure 3. Leaf assimilation ( $A_{\mathrm{n}}$, left-hand axis) and leaf transpiration ( $E_{1}$, right-hand axis) in relation to imposed values of stomatal conductance ( $g_{\mathrm{s}}$, bottom axis). Panel (a) shows SPAiWUE optimization and (b) shows SPA-WUE optimization. Results are for a warm, sunny day with relative humidity equal to $45 \%$ (solid lines) and $75 \%$ (dashed lines). Circles denote optimized values for $A_{\mathrm{n}}, E_{\mathrm{l}}$, and $g_{\mathrm{s}}$ at which (a) $\Delta A_{\mathrm{n}} / \Delta g_{\mathrm{s}}=5$, 7.5, 10, and $15 \mu \mathrm{mol} \mathrm{CO} \mathrm{mol}^{-1} \mathrm{H}_{2} \mathrm{O}$ (iWUE optimization) and (b) $\Delta A_{\mathrm{n}} / \Delta E_{1}=500,750,1000$, and $1500 \mu \mathrm{mol} \mathrm{CO} \mathrm{mol}^{-1} \mathrm{H}_{2} \mathrm{O}$ (WUE optimization). Open circles are with $45 \%$ relative humidity. Filled circles are with $75 \%$ relative humidity.

The simulations were evaluated in terms of root mean square error (RMSE) for each of the 51 site-years. Flux data for rainy time steps were excluded from the model-data analyses. We additionally evaluated model performance using Taylor diagrams (Taylor, 2001). Taylor diagrams quantify the degree of similarity between two fields, in this case the observed and simulated time series of a particular flux, in polar coordinate displays of the correlation coefficient $(r)$ and the standard deviation of the model data normalized by the standard deviation of the observations $\left(\hat{\sigma}_{\mathrm{sim}}=\sigma_{\mathrm{sim}} / \sigma_{\mathrm{obs}}\right)$. The radial distance of a data point from the origin is proportional

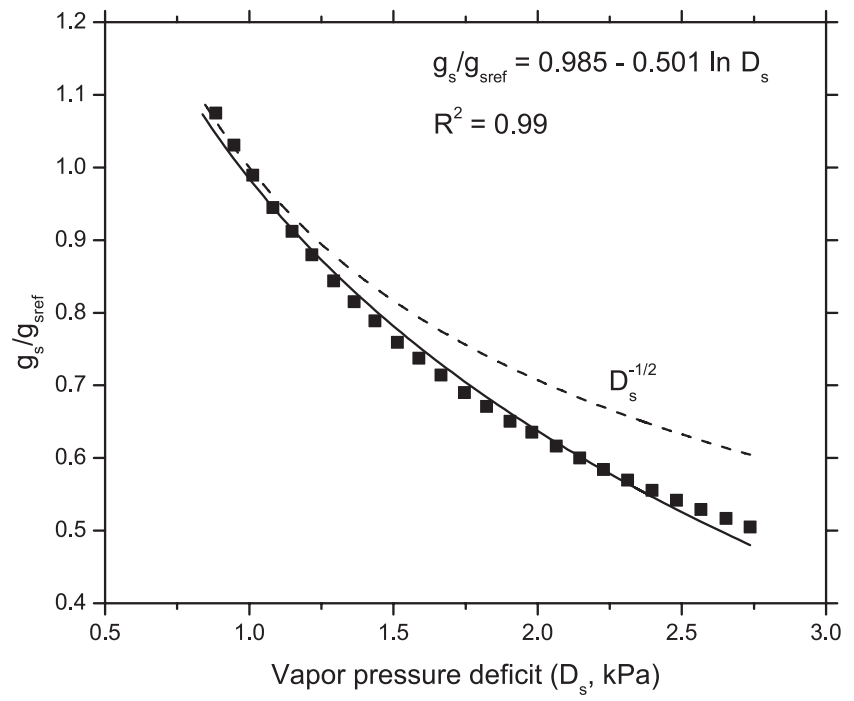

Figure 4. Relationship between $g_{\mathrm{S}}$ and $D_{\mathrm{S}}$ derived for SPAWUE optimization. $g_{\text {sref }}$ is the stomatal conductance at $D_{\mathrm{s}}=$ $1 \mathrm{kPa}$. The solid line shows the best-fit regression equation using the relationship $g_{\mathrm{s}} / g_{\text {sref }}=y_{0}+m \ln D_{\mathrm{S}}$ from Katul et al. (2009). The dashed line shows $D_{\mathrm{S}}^{-1 / 2}$. Calculations used $\iota=750 \mu \mathrm{mol} \mathrm{CO} \mathrm{mol}^{-1} \mathrm{H}_{2} \mathrm{O}$.

to the normalized standard deviation, and the azimuthal position gives the correlation coefficient between the two fields. The corresponding skill score is

$S=\frac{2(1+r)}{\left(\hat{\sigma}_{\text {sim }}+1 / \hat{\sigma}_{\text {sim }}\right)^{2}}$.

Stöckli et al. (2008) used Taylor plots to evaluate simulated and observed fluxes in previous versions of CLM, and Schwalm et al. (2010) used the skill score to assess model simulations of net ecosystem exchange across 22 models and 44 flux tower sites.

\subsubsection{Leaf-scale simulations}

We evaluated the SPA-iWUE and SPA-WUE stomatal optimization in four sets of leaf-scale analyses using meteorological forcing data from flux tower site US-Ha1 for July 2003:

1. We used one time slice of forcing data at midday to illustrate how stomatal efficiency $\left(\iota_{*}\right.$ or $\left.\iota\right)$ defines optimal $A_{\mathrm{n}}, E_{1}$, and $g_{\mathrm{s}}$. For the sunlit leaves at the top of the canopy, we calculated $A_{\mathrm{n}}$ and $E_{1}$ for specified values of $g_{\mathrm{s}}$ ranging from 0.005 to $1 \mathrm{~mol} \mathrm{H}_{2} \mathrm{O} \mathrm{m}^{-2} \mathrm{~s}^{-1}$, and then determined $g_{\mathrm{s}}$ at which the defined stomatal efficiency threshold ( $\iota_{*}$ for iWUE; and $\iota$ for WUE) was met. Atmospheric forcing was $T_{\text {ref }}=22.6^{\circ} \mathrm{C}, u_{\text {ref }}=$ $1.9 \mathrm{~m} \mathrm{~s}^{-1}, S \downarrow=852 \mathrm{~W} \mathrm{~m}^{-2}, L \downarrow=396 \mathrm{~W} \mathrm{~m}^{-2}, P_{\text {ref }}=$ $982.59 \mathrm{hPa}, c_{\mathrm{ref}}=367 \mu \mathrm{mol} \mathrm{mol}^{-1}$, and relative humidity $=45 \%$ (baseline) or increased to $75 \%$ to represent reduced vapor pressure deficit. 
2. We used the same forcing data as (1) to derive the dependence of $g_{\mathrm{s}}$ on vapor pressure deficit $\left(D_{\mathrm{S}}\right)$. Simulations calculated $g_{\mathrm{s}}$ for the SPA-WUE optimization over a range of relative humidity from 5 to $100 \%$.

3. We compared relationships between $A_{\mathrm{n}}$ and $g_{\mathrm{s}}$ simulated using the SPA-iWUE and SPA-WUE stomatal optimization with observations from the Glopnet leaf trait database (Wright et al., 2004). That database provides maximum $A_{\mathrm{n}}$ and $g_{\mathrm{s}}$ measured at high light, moist soil, and ambient $\mathrm{CO}_{2}$. For $\mathrm{C}_{3}$ plants, $A_{\mathrm{n}}$ ranged from 0.1 to $35 \mu \mathrm{mol} \mathrm{CO} \mathrm{Cm}^{-2} \mathrm{~s}^{-1}$, and $g_{\mathrm{s}}$ varied from $<0.05$ to $>1 \mathrm{~mol} \mathrm{H}_{2} \mathrm{O} \mathrm{m}^{-2} \mathrm{~s}^{-1}$. This reflects a range in photosynthetic capacity, seen in leaf nitrogen concentration that varied from $0.5 \%$ to $>4 \%$ (by mass). We generated similar model data for 100 theoretical leaves that differed in photosynthetic capacity, specified by varying $V_{\mathrm{c} \max 25}$ from 1.5 to $150 \mu \mathrm{mol} \mathrm{m} \mathrm{m}^{-2} \mathrm{~s}^{-1}$. The photosynthetic parameters $J_{\max 25}$ and $R_{\mathrm{d} 25}$ are proportional to $V_{\mathrm{c} \max 25}$ and so also varied. Simulations were for the sunlit leaf at the top of the canopy, at midday (high irradiance), and without water stress $\left(\psi_{1}>\psi_{1 \text { min }}\right)$. Six time slices of forcing data were used to sample a range of meteorological conditions. The range of conditions was $T_{\text {ref }}=22.5-27.5^{\circ} \mathrm{C}, u_{\text {ref }}=1.1-2.3 \mathrm{~m} \mathrm{~s}^{-1}$, relative humidity $=44-51 \%, \quad S \downarrow=852-895 \mathrm{~W} \mathrm{~m}^{-2}$, $L \downarrow=387-406 \mathrm{~W} \mathrm{~m}^{-2}, P_{\text {ref }}=976-985 \mathrm{hPa}$, and $c_{\text {ref }}=$ $367 \mu \mathrm{mol} \mathrm{mol}^{-1}$. We repeated these simulations for a range of stomatal efficiency parameters $\left(\iota_{*}=5\right.$ $15 \mu \mathrm{mol} \mathrm{CO} \mathrm{Col}^{-1} \mathrm{H}_{2} \mathrm{O}$ for iWUE optimization; $\iota=$ $500-1500 \mu \mathrm{mol} \mathrm{CO}_{2} \mathrm{~mol}^{-1} \mathrm{H}_{2} \mathrm{O}$ for WUE optimization).

4. We compared $g_{\mathrm{S}}$ simulated by the SPA-iWUE and SPAWUE stomatal optimization with $A_{\mathrm{n}} / c_{\mathrm{s}} h_{\mathrm{s}}$ (Ball et al., 1987 ) and $A_{\mathrm{n}} / c_{\mathrm{S}} D_{\mathrm{S}}^{-1 / 2}$ (Medlyn et al., 2011b). Analyses used results for the sunlit leaves at the top of the canopy, obtained from simulations for the entire month of July 2003 at US-Ha1. We performed these simulations using 11 values of $\iota_{*}\left(5-15 \mu \mathrm{mol} \mathrm{CO}_{2} \mathrm{~mol}^{-1} \mathrm{H}_{2} \mathrm{O}\right)$ for iWUE optimization and 11 values of $\iota(500$ $1500 \mu \mathrm{mol} \mathrm{CO}_{2} \mathrm{~mol}^{-1} \mathrm{H}_{2} \mathrm{O}$ ) for WUE optimization. Environmental conditions were absorbed photosynthetically active radiation, $7-1288 \mu \mathrm{mol} \mathrm{m}^{-2} \mathrm{~s}^{-1} ; T_{1}$, $12-33^{\circ} \mathrm{C} ; h_{\mathrm{s}}, 0.42-1.0 ; D_{\mathrm{s}}, 0-2.6 \mathrm{kPa}$; and $A_{\mathrm{n}}, 0-$ $13 \mu \mathrm{mol} \mathrm{CO} 2 \mathrm{~m}^{-2} \mathrm{~s}^{-1}$

\section{Results}

\subsection{Leaf-scale analyses}

Figure 3 illustrates the SPA stomatal optimization and the role of stomatal efficiency in determining the optimal $g_{\mathrm{s}}, A_{\mathrm{n}}$, and $E_{1}$ under well-watered conditions (so that $\psi_{1}>\psi_{1 \mathrm{~min}}$ ).
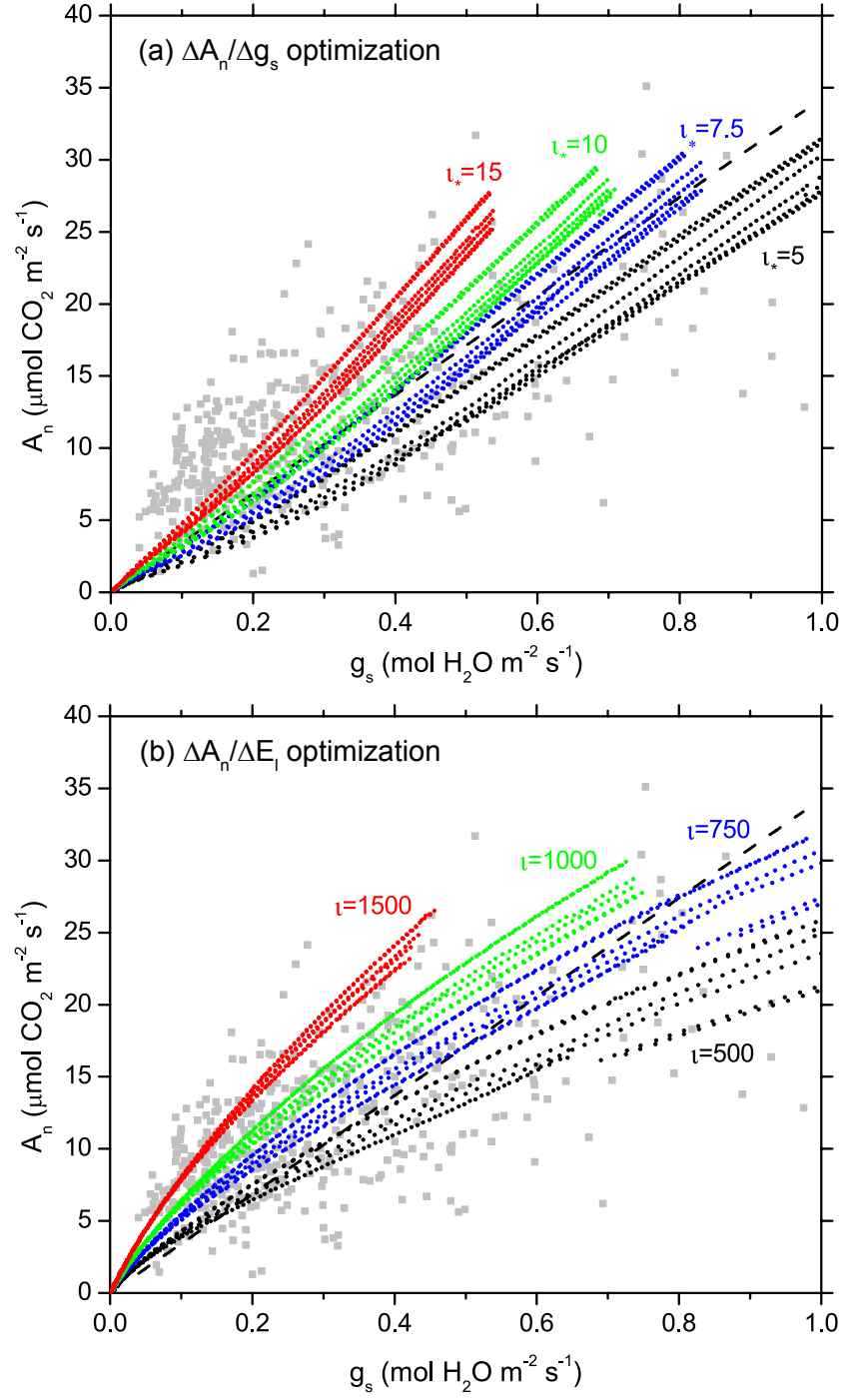

Figure 5. Observed and simulated relationships between $A_{\mathrm{n}}$ and $g_{\mathrm{s}}$. Observations (light grey symbols) are from the Glopnet leaf trait database (Wright et al., 2004) for $C_{3}$ plants $(n=421)$. The dashed line shows the best-fit regression equation, $A_{\mathrm{n}}=34.3 g_{\mathrm{s}}$. Simulations show optimal $A_{\mathrm{n}}$ and $g_{\mathrm{s}}$ calculated for 100 theoretical leaves that differed in photosynthetic capacity, specified by varying $V_{\text {c } \max 25}$ from $1.5-150 \mu \mathrm{mol} \mathrm{m}{ }^{-2} \mathrm{~s}^{-1}$. (a) SPA-iWUE optimization simulations with $\iota_{*}=5,7.5,10$, and $15 \mu \mathrm{mol} \mathrm{CO} \mathrm{Col}^{-1} \mathrm{H}_{2} \mathrm{O}$. (b) SPA-WUE optimization simulations with $\iota=500,750,1000$, and $1500 \mu \mathrm{mol} \mathrm{CO} \mathrm{mol}^{-1} \mathrm{H}_{2} \mathrm{O}$. The model simulations used six different meteorological forcings, producing six different $A_{\mathrm{n}}-g_{\mathrm{s}}$ relationships for each value of stomatal efficiency.

In these calculations, $g_{\mathrm{s}}$ was specified, and $A_{\mathrm{n}}$ and $E_{1}$ were calculated for that conductance. The calculated $A_{\mathrm{n}}$ and $E_{1}$ increase with higher $g_{s}$. For both iWUE and WUE optimization, higher values of stomatal efficiency result in both lower $A_{\mathrm{n}}, E_{1}$, and $g_{\mathrm{s}}$ at optimization (denoted by open and closed circles in the figure) and higher water-use efficiency. Consider, for example, the iWUE optimization (Fig. 3a): 
$A_{\mathrm{n}} / E_{1}=3.8 \mathrm{mmol} \mathrm{CO} \mathrm{mol}^{-1} \mathrm{H}_{2} \mathrm{O}$ with $\iota_{*}=5$, whereas $A_{\mathrm{n}} / E_{1}=5.1 \mathrm{mmol} \mathrm{CO} \mathrm{mol}^{-1} \mathrm{H}_{2} \mathrm{O}$ with $\iota_{*}=15$ (both at $75 \%$ relative humidity). Similar behavior occurs at $45 \%$ relative humidity, and with WUE optimization (Fig. 3b). The two optimization algorithms differ in their response to changes in vapor pressure deficit. With iWUE optimization, the optimal $g_{\mathrm{s}}$ and $A_{\mathrm{n}}$ are nearly insensitive to lower relative humidity (Fig. 3a). With WUE optimization, the optimal $g_{\mathrm{s}}$ and $A_{\mathrm{n}}$ both decrease with lower relative humidity (Fig. $3 \mathrm{~b}$ ).

The WUE optimization produces a sharp reduction in $g_{\mathrm{s}}$ as $D_{\mathrm{s}}$ increases (Fig. 4). In these simulations, air temperature was held constant $\left(T_{\text {ref }}=22.6^{\circ} \mathrm{C}\right)$ and relative humidity varied from 5 to $100 \%$ so that $D_{\mathrm{s}}$ varied from 0.8 to $2.7 \mathrm{kPa}$. Leaf temperature was nearly constant, but decreased from $29.1^{\circ} \mathrm{C}$ to $27.0^{\circ} \mathrm{C}$ as $D_{\mathrm{s}}$ increased. The decrease in $g_{\mathrm{s}}$ follows the relationship $g_{\mathrm{s}} / g_{\text {sref }}=1-m \ln D_{\mathrm{s}}$, expected from water-use efficiency optimization theory (Katul et al., 2009), and the slope (0.5) is consistent with observations ( $m=0.5-$ $0.6)$ for over 40 species of grasses, deciduous trees, and evergreen trees (Oren et al., 1999; Katul et al., 2009). Simulations using several different values of stomatal efficiency show that over the range $\iota=500-1250 \mu \mathrm{mol} \mathrm{CO}_{2} \mathrm{~mol}^{-1} \mathrm{H}_{2} \mathrm{O}, g_{\text {sref }}$ decreases from 0.41 to $0.24 \mathrm{~mol} \mathrm{H}_{2} \mathrm{O} \mathrm{m}^{-2} \mathrm{~s}^{-1}$, but $m$ is conserved in the range $0.58-0.48$, consistent with observations (Oren et al., 1999; Katul et al., 2009). The relationship $1-0.5 \ln D_{\mathrm{S}}$ is itself an approximation of $D_{\mathrm{s}}^{-1 / 2}$ for $D_{\mathrm{s}}<\sim 2.0 \mathrm{kPa}$ (Katul et al., 2009).

With iWUE and WUE optimization, the optimal $A_{\mathrm{n}}$ and $g_{\mathrm{S}}$ increase in relation to each other (Fig. 5). This is consistent with the range of observations of maximum $A_{\mathrm{n}}$ and $g_{\mathrm{s}}$ from the Glopnet leaf trait database, but direct comparisons are not possible because of uncertainties in the conditions for which the observations were obtained. The observed measurements reflect maximum rates obtained for high light, moist soils, and ambient $\mathrm{CO}_{2}$. For similar conditions, the stomatal optimization simulates comparable increases in $A_{\mathrm{n}}$ with higher $g_{\mathrm{s}}$. With iWUE optimization, the slope of the simulated $A_{\mathrm{n}}-g_{\mathrm{s}}$ relationship increases with larger values of $\iota_{*}$ (i.e., larger $\iota_{*}$ produces higher $A_{\mathrm{n}}$ for a given $g_{\mathrm{s}}$ ). Values of $\iota_{*}$ equal to 7.5 and $10 \mu \mathrm{mol} \mathrm{CO}_{2} \mathrm{~mol}^{-1} \mathrm{H}_{2} \mathrm{O}$ generally bracket the empirical relationship, while 5 and $15 \mu \mathrm{mol} \mathrm{CO}_{2} \mathrm{~mol}^{-1} \mathrm{H}_{2} \mathrm{O}$ are biased low and high, respectively (Fig. 5a). Similarly for WUE optimization, $\iota$ equal to 750 and $1000 \mu \mathrm{mol} \mathrm{CO}_{2} \mathrm{~mol}^{-1} \mathrm{H}_{2} \mathrm{O}$ match the middle of the scatter plot, while 500 and $1500 \mu \mathrm{mol} \mathrm{CO}_{2} \mathrm{~mol}^{-1} \mathrm{H}_{2} \mathrm{O}$ are biased low and high, respectively (Fig. 5b). The iWUE simulations (without vapor pressure deficit) have a linear response; the WUE simulations (with dependence on vapor pressure deficit) have a curvilinear response. The curvilinear response arises from interactions among stomatal conductance, leaf temperature, and vapor pressure deficit.

Leaf analyses over a range of photosynthetically active radiation $\left(7-1288 \mu \mathrm{mol} \mathrm{m}^{-2} \mathrm{~s}^{-1}\right)$, temperature $\left(12-33^{\circ} \mathrm{C}\right)$, and vapor pressure deficit $(0-2.6 \mathrm{kPa})$ show (a) $\Delta A_{n} / \Delta g_{s}$ optimization

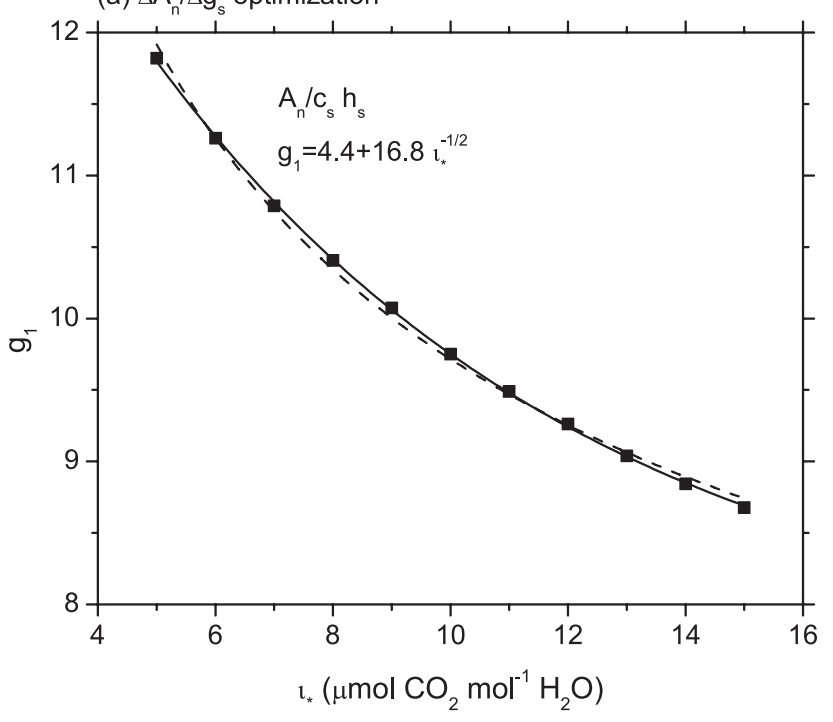

(b) $\Delta A_{n} / \Delta E_{\text {, optimization }}$

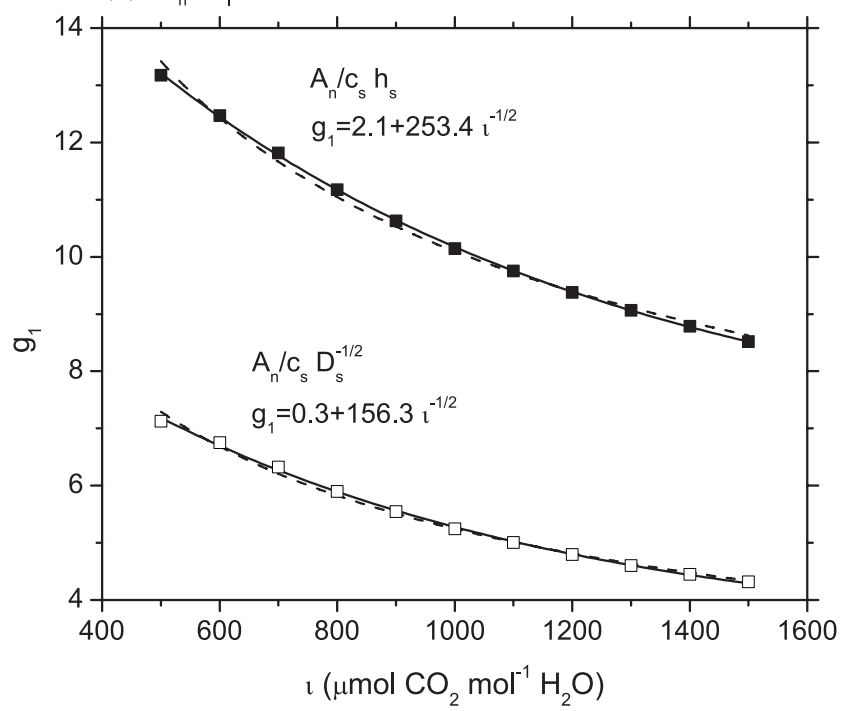

Figure 6. Slope $\left(g_{1}\right)$ of empirical stomatal models in relation to stomatal efficiency. (a) SPA-iWUE optimization with the slope $g_{1}$ defined for $g_{\mathrm{S}} \propto A_{\mathrm{n}} / c_{\mathrm{S}} h_{\mathrm{S}}$. (b) SPA-WUE optimization with the slope $g_{1}$ defined for $g_{\mathrm{S}} \propto A_{\mathrm{n}} / c_{\mathrm{S}} h_{\mathrm{S}}$ (closed symbols) and $g_{\mathrm{s}} \propto$ $A_{\mathrm{n}} / c_{\mathrm{S}} D_{\mathrm{S}}^{-1 / 2}$ (open symbols). Solid lines show an exponential regression equation $\left(R^{2}=0.99\right)$. Dashed lines show the fit to $\iota_{*}^{-1 / 2}$ (a) and $\iota^{-1 / 2}$ (b).

that the optimized $g_{\mathrm{s}}$ is linearly related to $A_{\mathrm{n}} / c_{\mathrm{s}} h_{\mathrm{s}}$. Stomatal conductance simulated with iWUE optimization (using $\iota_{*}=7.5 \mu \mathrm{mol} \mathrm{CO}_{2} \mathrm{~mol}^{-1} \mathrm{H}_{2} \mathrm{O}$ ) is significantly correlated with $A_{\mathrm{n}} / c_{\mathrm{s}} h_{\mathrm{s}}$ (slope $g_{1}=10.6, \quad r=0.95$, $p<0.001$ ), as shown also by Williams et al. (1996). Stomatal conductance simulated with WUE optimization (using $\iota=750 \mu \mathrm{mol} \mathrm{CO}_{2} \mathrm{~mol}^{-1} \mathrm{H}_{2} \mathrm{O}$ ) is well-described by $A_{\mathrm{n}} / c_{\mathrm{s}} h_{\mathrm{s}} \quad\left(g_{1}=11.5, \quad r=0.98, \quad p<0.001\right), \quad$ and 

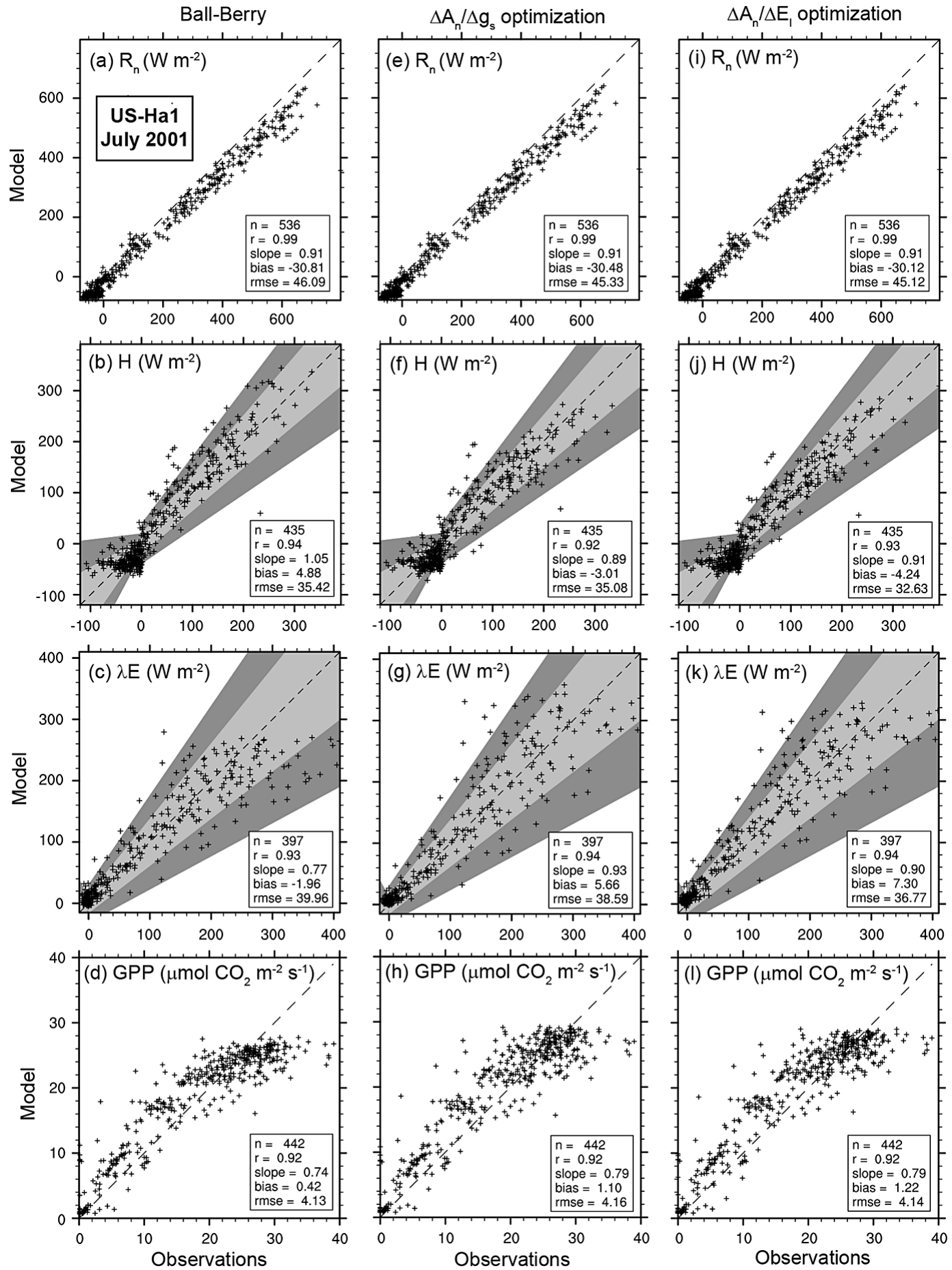

Figure 7. Canopy flux simulations for US-Ha1, July 2001. Shown are observed (horizontal axis) and simulated (vertical axis) net radiation $\left(R_{\mathrm{n}}\right)$, sensible heat flux $(H)$, latent heat flux $(\lambda E)$, and gross primary production (GPP) for the multi-layer canopy model with the CLM Ball-Berry model (left-hand panels; a-d), SPA-iWUE optimization (middle panels; $\mathbf{e}-\mathbf{h}$ ), and SPA-WUE optimization (right-hand panels, i-l). The dashed line shows the $1: 1$ relationship, with the light and dark shading denoting \pm 1 and \pm 2 standard deviations, respectively, of the random flux error, $\sigma(\varepsilon)$. Statistics show sample size $(n)$, correlation coefficient $(r)$, slope of the regression line, mean bias, and root mean square error (RMSE). Data are shown for periods without rain. GPP is for daylight hours only. 
also by $A_{\mathrm{n}} / c_{\mathrm{s}} D_{\mathrm{s}}^{-1 / 2}\left(g_{1}=6.1, \quad r=0.91, \quad p<0.001\right)$. Analyses using data simulated with 11 different values of $\iota_{*}\left(5-15 \mu \mathrm{mol} \mathrm{CO}_{2} \mathrm{~mol}^{-1} \mathrm{H}_{2} \mathrm{O}\right)$ and $\iota$ (500$\left.1500 \mu \mathrm{mol} \mathrm{CO} \mathrm{Col}^{-1} \mathrm{H}_{2} \mathrm{O}\right)$ show that the slope $\left(g_{1}\right)$ of these relationships decreases with higher stomatal efficiency (Fig. 6). The dependence of $g_{1}$ on stomatal efficiency closely approximates $\iota_{*}^{-1 / 2}$ and $\iota^{-1 / 2}$, as expected from theory (Medlyn et al., 2011b).

\subsection{Canopy-scale analyses}

Figure 7 compares observed fluxes for US-Ha1 during July 2001 and simulated fluxes for the three multi-layer canopy stomatal models. Net radiation is biased low at high radiation for each model. Sensible heat flux is comparable among models. Each replicates the observations equally well, and model fluxes fall within the random error of the observed fluxes. The CLM-BB model underestimates latent heat flux at high values, and the SPA-iWUE and SPA-WUE optimizations better match the observations, but the simulated fluxes fall within the random error of the observed fluxes for each model. Gross primary production is similarly comparable among the models.

Taylor diagrams show that across the years 1992-2006 the three multi-layer canopy stomatal models are each improved relative to CLM4.5, seen mainly in improved variance of the modeled fluxes relative to the observations; improvements in the correlation with the observations are minor (Fig. 8). Sensible heat flux simulated with the CLM-BB model is improved relative to CLM4.5, primarily by lower standardized deviations relative to the observations. The SPA-iWUE and SPA-WUE stomatal optimizations are further improved in terms of standardized deviations, but are both similar. The CLM-BB model simulates latent heat flux comparable to CLM4.5; the SPA stomatal optimizations are improved compared with CLM-BB (higher standardized deviations). Gross primary production simulated with the CLM-BB model is improved compared with CLM4.5, and the SPA stomatal optimizations further match the observations with higher standardized deviations.

Similar results are seen at other sites (Fig. 9). The skill of the multi-layer canopy model is generally similar to or improved relative to CLM4.5 for sensible heat flux, latent heat flux, and GPP across sites and for all three stomatal models. The SPA stomatal optimization models generally have similar or improved skill compared with the CLM-BB model. Large improvements in sensible heat flux, latent heat flux, and GPP are seen at US-Me2 with the multi-layer model compared with CLM4.5 and with the SPA stomatal optimization models compared with CLM-BB.

At US-Me2, CLM4.5 overestimates the standardized deviations for sensible heat flux compared with the observations (Fig. 10a). The multi-layer canopy reduces the deviations, and the SPA stomatal optimization models are improved relative to the CLM-BB model. CLM4.5 and the
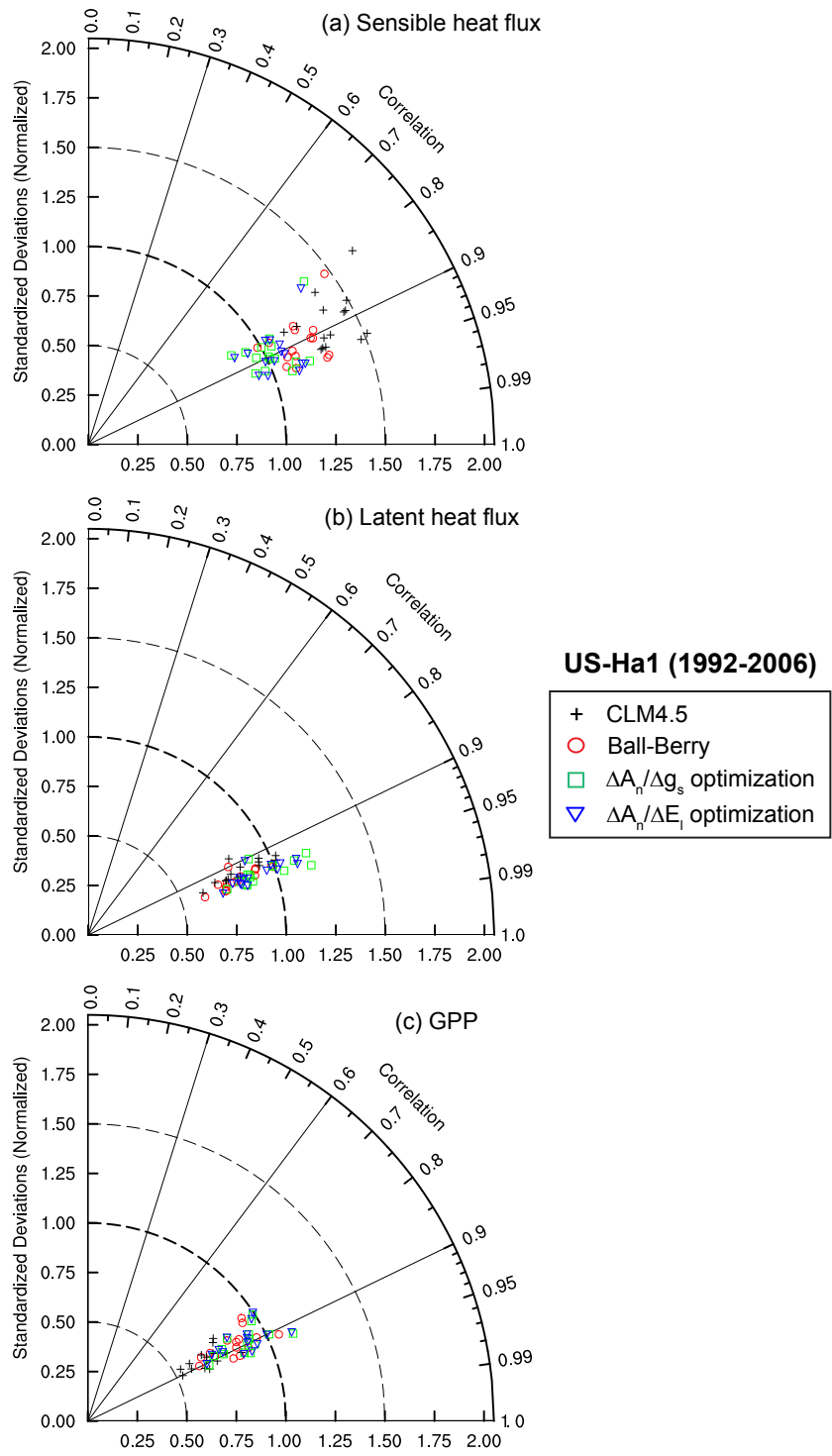

Figure 8. Taylor diagram of (a) sensible heat flux, (b) latent heat flux, and (c) gross primary production for US-Ha1. Data points are for the years 1992-2006 for CLM4.5 and the multi-layer canopy model with the CLM Ball-Berry model, SPA-iWUE optimization, and SPA-WUE optimization. Simulations are evaluated by the normalized standard deviation relative to the observations (given by the radial distance of a data point from the origin) and the correlation with the observations (given by the azimuthal position).

CLM-BB model underestimate latent heat flux standardized deviations; the SPA-iWUE optimization overestimates the deviations; and the SPA-WUE optimization is closer to the observations (Fig. 10b). Marked differences among models are seen in GPP (Fig. 10c). CLM4.5 underestimates the standardized deviations and has low correlation with the observations. The multi-layer canopy model performs better. The CLM-BB model has higher correlation than CLM4.5, and the SPA-iWUE and SPA-WUE optimizations have still higher 

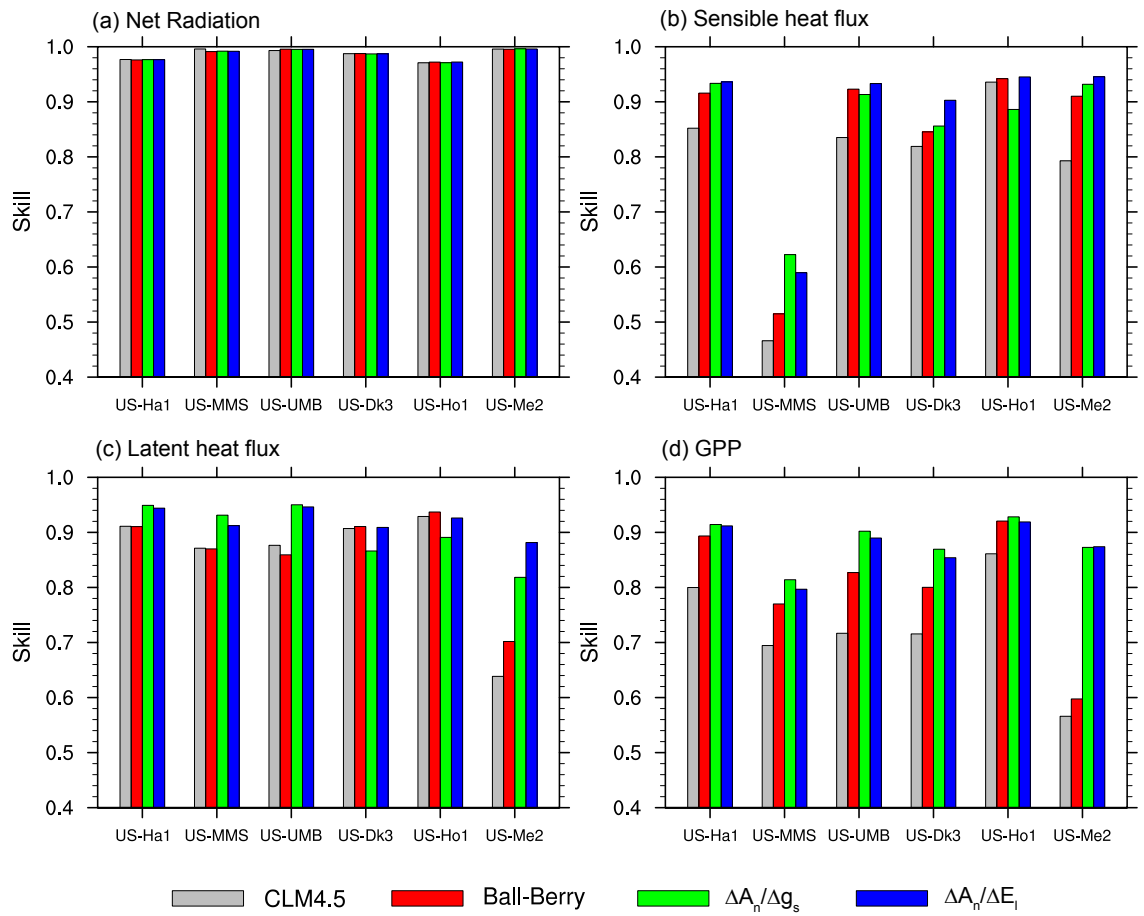

Figure 9. Average skill across all years for each flux tower site for (a) net radiation, (b) sensible heat flux, (c) latent heat flux, and (d) gross primary production. Shown are simulations for CLM4.5 and the multi-layer canopy model with the CLM Ball-Berry model, SPA-iWUE optimization, and SPA-WUE optimization. Stomatal efficiency is $\iota_{*}=15 \mu \mathrm{mol} \mathrm{CO}_{2} \mathrm{~mol}^{-1} \mathrm{H}_{2} \mathrm{O}$ (iWUE optimization) and $\iota=1500 \mu \mathrm{mol} \mathrm{CO} 2 \mathrm{~mol}^{-1} \mathrm{H}_{2} \mathrm{O}$ (WUE optimization) for US-Ho1 and US-Me2. All other parameter values are as in Table 3.

correlation and standardized deviations comparable to the observations.

The improvements at US-Me2 with the SPA stomatal optimization models compared with the CLM-BB model are related to the simulation of soil moisture stress in the stomatal models. The year 2002 had a persistent drought throughout the month of July (Fig. 11). The CLM4.5 soil wetness factor $\left(\beta_{t}\right)$ used in the Ball-Berry model is low and decreases throughout the month. The leaf-specific hydraulic conductance simulated by the SPA-WUE optimization is similarly low and decreases throughout the month. The CLM-BB model underestimates high midday peak latent heat flux seen in the observations and systematically underestimates GPP. In contrast, the SPA-WUE optimization better replicates latent heat flux and GPP. These differences among stomatal models are evident in scatter plots of observed and simulated fluxes (Fig. 12). The CLM-BB model overestimates sensible heat flux and underestimates latent heat flux and GPP. The SPA-iWUE optimization overestimates latent heat flux and GPP. The SPA-WUE optimization is improved compared with the SPA-iWUE optimization. The failure of the CLM$\mathrm{BB}$ model is related to the implementation of soil moisture stress. Increasing the soil wetness factor $\left(\beta_{t}\right)$ by 0.3 increases latent heat flux and GPP and improves the simulation (Fig. 12m-p).
In 2005, drought developed at US-Me2 in the later twothirds of the month (Fig. 13). The CLM-BB and SPA-WUE optimization models both replicate the observed latent heat flux prior to severe soil moisture stress and similarly replicate the decline in latent heat flux as soil moisture stress increases. The CLM-BB model matches the observed GPP prior to development of soil moisture stress, but as the water stress progresses GPP is biased low. The SPA-WUE optimization simulates GPP consistent with the observations throughout the month. Increasing the soil wetness factor $\left(\beta_{t}\right)$ by 0.3 improves GPP for the CLM-BB model without substantially degrading latent heat flux (not shown).

The importance of soil moisture stress is further highlighted by SPA-iWUE and SPA-WUE simulations that eliminated stomatal closure when leaf water potential $\left(\psi_{1}\right)$ decreased below $\psi_{1 \text { min }}$ (this removed stomatal dependence on soil moisture). The greatest difference in these simulations compared with the full model is seen in latent heat flux and GPP on sites that are drought stressed (data not shown). At US-Me 2 during the July 2002 drought, for example, latent heat flux in the SPA-WUE simulation is overestimated with removal of $\psi_{1 \mathrm{~min}}$, and the model skill declines from 0.92 to 0.81 . GPP is similarly overestimated, and the skill declines from 0.91 to 0.86 . Sensible heat flux skill is unchanged. Similar results are seen in July 2005. The reduction in model skill is greater for the SPA-iWUE optimization, for which the 

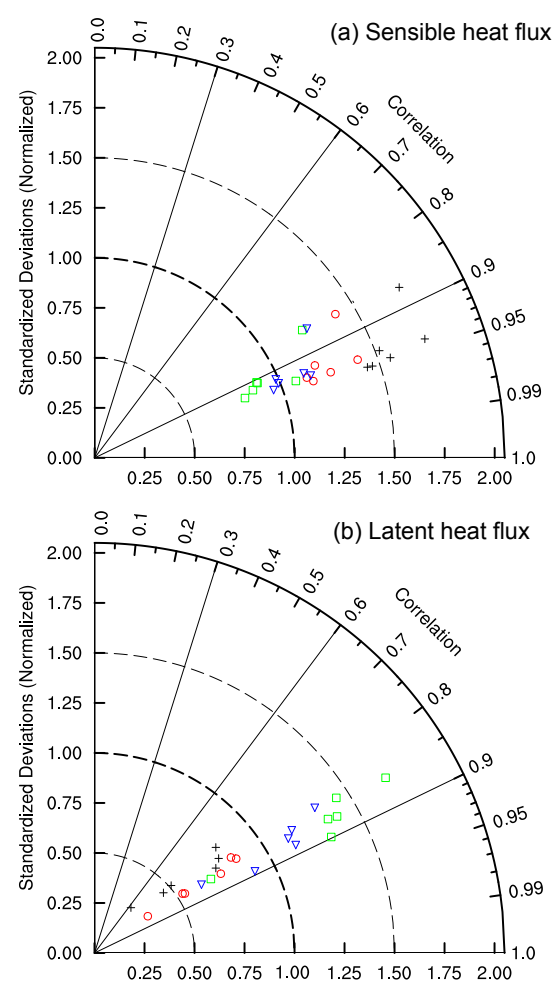

US-Me2 (2002-2007)

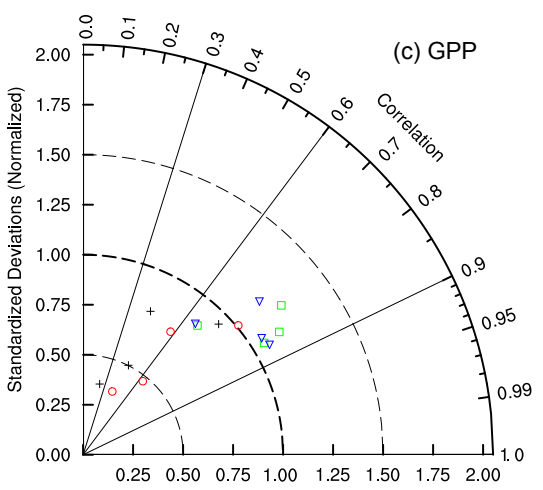

Figure 10. As in Fig. 8, but for US-Me2 (2002-2007).

decline in $\psi_{1}$ with high transpiration rates is a key regulator of stomatal conductance. At US-Me2 during the July 2002 drought, removing this control of stomatal conductance decreases the latent heat flux skill from 0.86 to 0.42 ; GPP skill decreases from 0.92 to 0.69 ; and sensible heat flux skill decreases from 0.96 to 0.79 . At other flux tower sites, where soil water stress is less important, the skill of the model is not greatly affected when soil water stress is neglected.

The SPA stomatal optimization simulations for US-Ho1 and US-Me2 used a higher stomatal efficiency $\left(\iota_{*}=15\right.$ and $\left.\iota=1500 \mu \mathrm{mol} \mathrm{CO}_{2} \mathrm{~mol}^{-1} \mathrm{H}_{2} \mathrm{O}\right)$ than the other sites $\left(\iota_{*}=7.5\right.$ and $\iota=750 \mu \mathrm{mol} \mathrm{CO} \mathrm{mol}^{-1} \mathrm{H}_{2} \mathrm{O}$ ). The higher stomatal efficiency improved the simulation of sensible heat flux, latent heat flux, and GPP compared with the lower value, for both the iWUE and WUE optimizations at US-Ho1 and US-Me2

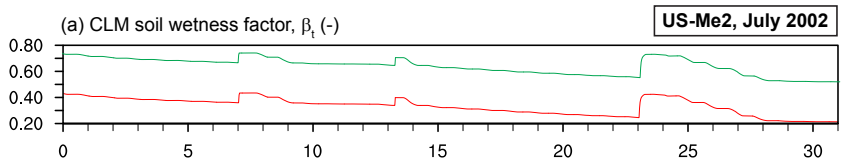

(b) Leaf-specific conductance (mmol $\left.\mathrm{H}_{2} \mathrm{O} \mathrm{m}^{-2} \mathrm{~s}^{-1} \mathrm{MPa}^{-1}\right)$

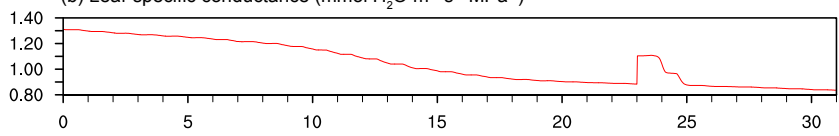

(c) Fraction of canopy water stressed $\left(\psi_{L}=\psi_{L \text { min }}\right)$

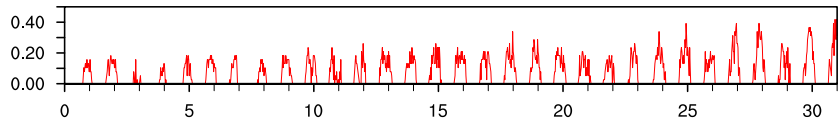

(d) Latent heat flux, Ball-Berry ( $\left.\mathrm{W} \mathrm{m}^{-2}\right)$

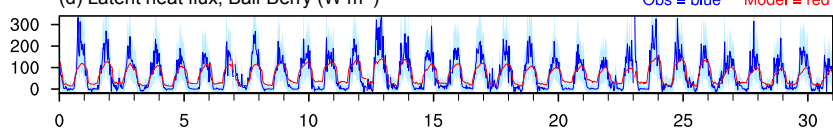

(e) Latent heat flux, $\Delta \mathrm{A}_{\mathrm{n}} / \Delta \mathrm{E}_{\text {, optimization }}\left(\mathrm{W} \mathrm{m}^{-2}\right)$

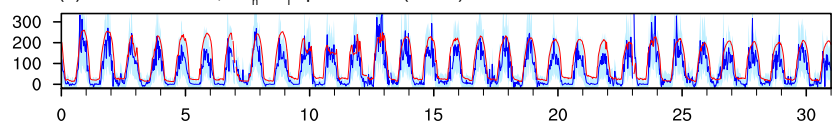

(f) GPP, Ball-Berry ( $\left.\mu \mathrm{mol} \mathrm{CO} \mathrm{CO}_{2} \mathrm{~m}^{-2} \mathrm{~s}^{-1}\right)$

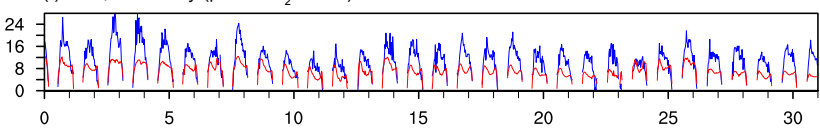

(g) GPP, $\Delta A_{n} / \Delta E_{1}$ optimization $\left(\mu \mathrm{mol} \mathrm{CO}_{2} \mathrm{~m}^{-2} \mathrm{~s}^{-1}\right)$

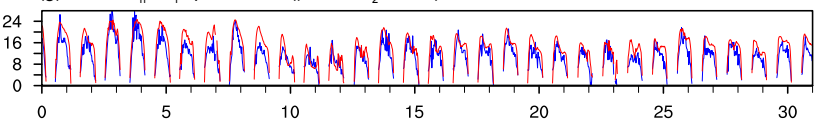

Figure 11. Multi-layer canopy model simulations for US-Me2 for 31 days in July 2002 during a prolonged drought. (a) CLM4.5 soil wetness factor $\left(\beta_{t}\right)$. The green line shows $\beta_{t}$ increased by 0.3 , needed to improve latent heat flux and GPP simulations with the CLM Ball-Berry model. (b) Leaf-specific conductance $\left(k_{\mathrm{L}}\right)$ with SPA-WUE optimization. (c) Fraction of canopy that is water stressed with SPA-WUE optimization. (d, e) Latent heat flux simulated with the CLM Ball-Berry model and SPA-WUE optimization (red) compared with observations (blue). The light blue shading denotes \pm 2 standard deviations of the random flux error, $\sigma(\varepsilon)$. (f, g) Gross primary production simulated with the CLM Ball-Berry model and SPA-WUE optimization (red) compared with observations (blue).

(Fig. 14). Similar or improved results were also obtained with higher root resistivity $\left(R_{\mathrm{r}}^{*}=75 \mathrm{MPa} \mathrm{s} \mathrm{g} \mathrm{mol}^{-1} \mathrm{H}_{2} \mathrm{O}\right)$ compared with the baseline value $\left(R_{\mathrm{r}}^{*}=25\right)$. Both parameters decreased maximum latent heat flux and GPP compared with the lower parameter values. At US-Dk3, however, the higher parameter values degraded the model skill, particularly for the WUE optimization.

\subsection{Parameter sensitivity analyses}

Latin hypercube parameter sampling failed to distinguish optimal parameter values for $g_{0}$ and $g_{1}$ in the CLM-BB model that minimized model error. This is illustrated in Fig. 15 for 

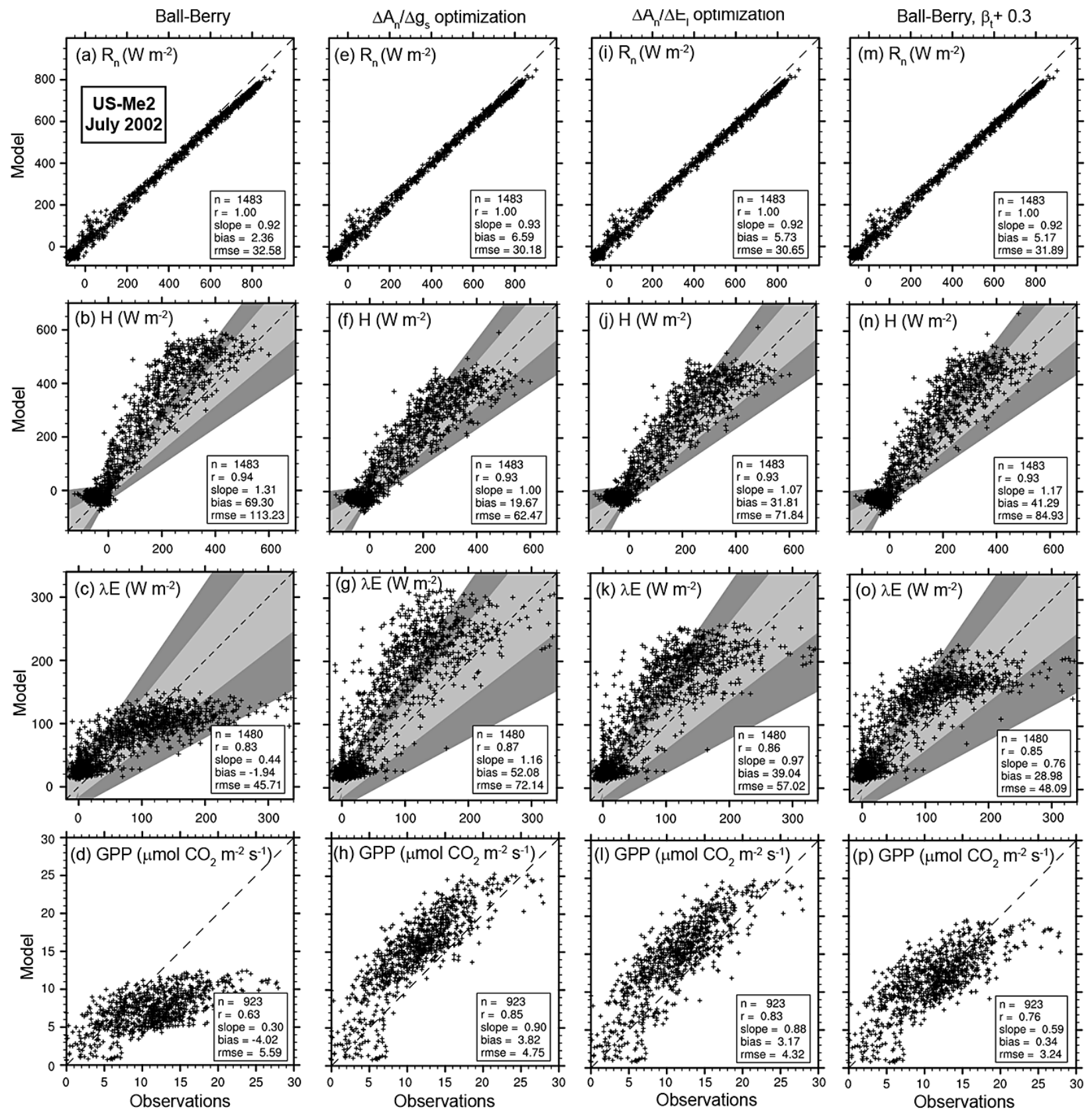

Figure 12. As in Fig. 7, but for US-Me2, July 2002. Also shown are simulations for the CLM Ball-Berry model with $\beta_{t}$ increased by 0.3 (m-p).

US-Ha1 during July 2001. The 50 simulations with the lowest RMSE (i.e., the lowest $10 \%$ of the 500 parameter tries) have comparable RMSE with the baseline simulation shown in Fig. 7. Values of $g_{0}>0.05 \mathrm{~mol} \mathrm{H}_{2} \mathrm{O} \mathrm{m}^{-2} \mathrm{~s}^{-1}$ were discriminated against, but values $<0.01 \mathrm{~mol} \mathrm{H}_{2} \mathrm{O} \mathrm{m}^{-2} \mathrm{~s}^{-1}$ also gave low RMSE (Fig. 15a). Values of $g_{1}$ in the 50 simulations with the lowest RMSE ranged from 6 to 12 (Fig. 15b). This is because there is a negative correlation between $g_{0}$ and $g_{1}$ in the simulations with low model error (Fig. 16). Similar results occur across other sites and years. Parameter estimation analyses that vary only $g_{0}$ or $g_{1}$ may erroneously produce acceptable simulations.

Well-defined values of stomatal efficiency and root resistivity minimized model error for the SPA-WUE stomatal optimization (Fig. 17). Optimal parameter values varied from about $600-950 \mu \mathrm{mol} \mathrm{CO} \mathrm{Col}^{-1} \mathrm{H}_{2} \mathrm{O}$ for $\iota$ and 25$100 \mathrm{MPasg} \mathrm{mmol}^{-1} \mathrm{H}_{2} \mathrm{O}$ for $R_{\mathrm{r}}^{*}$. The baseline parameter values (Table 3) are within this range. Other aboveground and belowground parameters did not differentiate between prior and posterior values. This is because $\iota$ explains $97 \%$ of 

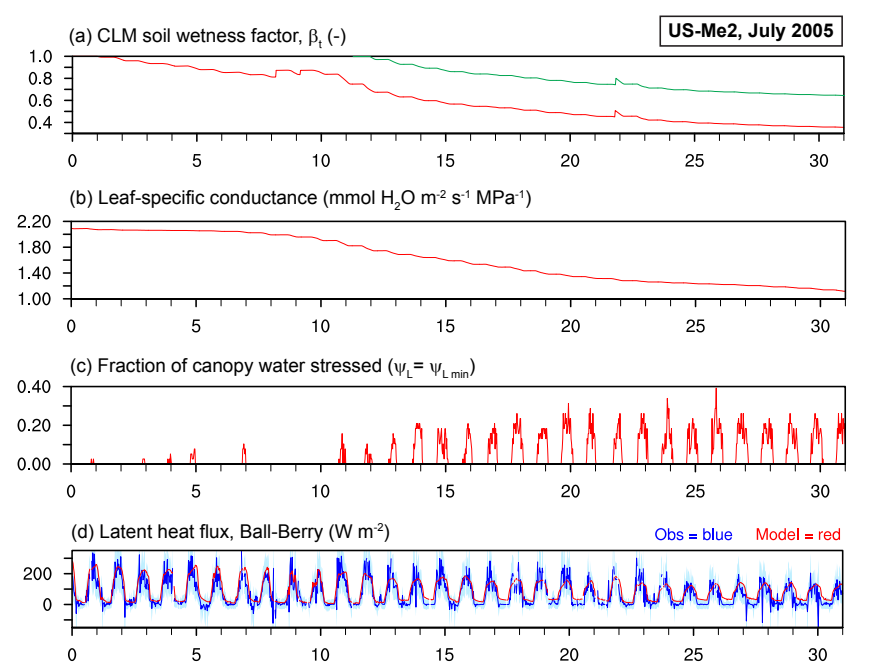

(e) Latent heat flux, $\Delta \mathrm{A}_{\mathrm{n}} / \Delta \mathrm{E}_{1}$ optimization $\left(\mathrm{W} \mathrm{m}^{-2}\right)$

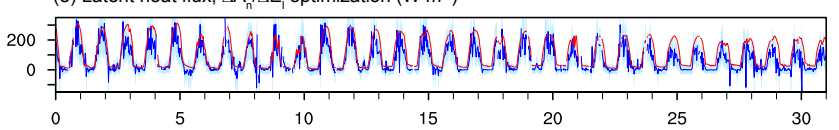

(f) GPP, Ball-Berry ( $\left.\mu \mathrm{mol} \mathrm{CO}_{2} \mathrm{~m}^{-2} \mathrm{~s}^{-1}\right)$
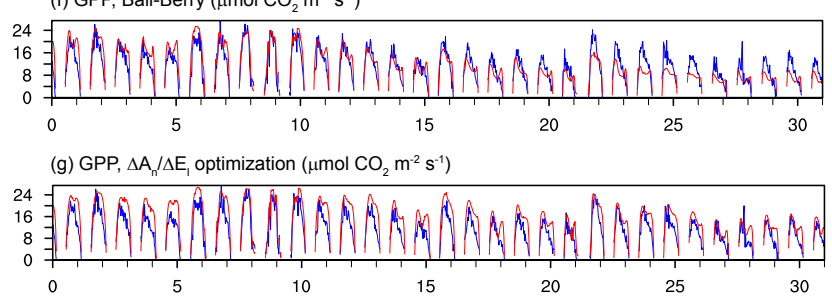

Figure 13. As in Fig. 11, but for July 2005 during an evolving drought.

the variation in RMSE in the simulations that varied the four aboveground plant parameters (Fig. 18a). Root resistivity explains $85 \%$ of the variation in RMSE in the simulations that varied the four belowground root parameters (Fig. 18b). The scatter about the regression line in Fig. $18 \mathrm{~b}$ arises from an additional dependence with fine root biomass $\left(M_{T}\right)$, in which RMSE decreases as $M_{T}$ increases after accounting for $R_{\mathrm{r}}^{*}$. Similar results occur across other sites and years.

\section{Discussion}

The multi-layer canopy model simulates sensible heat flux and latent heat flux across sites and years that are comparable to or improved relative to CLM4.5; GPP is significantly improved by the multi-layer approach (compare CLM4.5 and the CLM-BB model, Fig. 9). CLM4.5 uses a big-leaf canopy parameterization (with sunlit and shaded fractions). A steep decline in leaf nitrogen with depth in the canopy $\left(K_{\mathrm{n}}=0.3\right)$ is needed to decrease photosynthetic capacity $\left(V_{\mathrm{c} \max 25}\right)$ and compensate for inadequacies in the absorption of diffuse radiation by shaded leaves in the big-leaf parameterization (Bonan et al., 2012). The multi-layer canopy model uses a
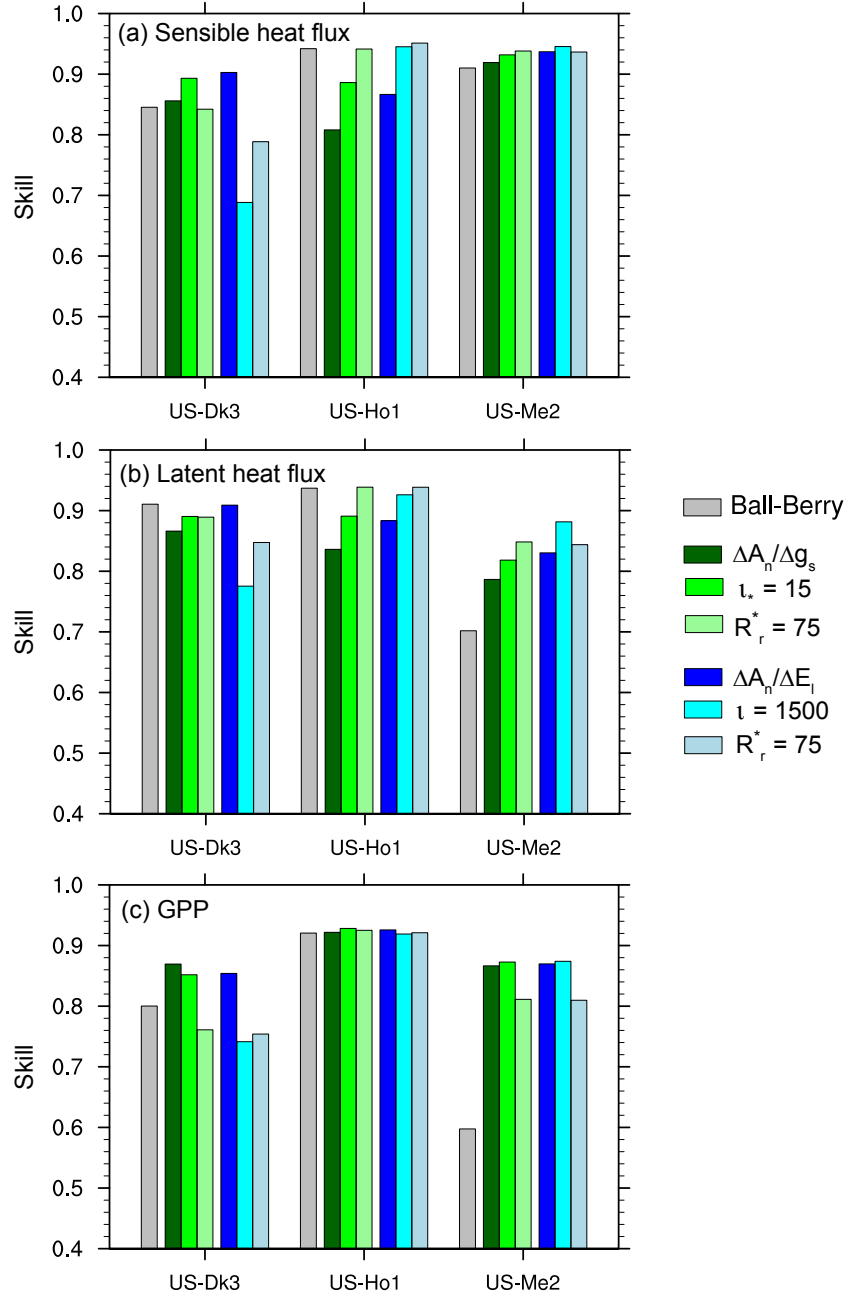

Figure 14. Average skill across all years for evergreen needleleaf forest tower sites for (a) sensible heat flux, (b) latent heat flux, and (c) gross primary production. Simulations are the multi-layer canopy model with the CLM Ball-Berry model, SPA-iWUE optimization, and SPA-WUE optimization using baseline parameter values (Table 3). Four additional simulations are shown with higher stomatal efficiency $\left(\iota_{*}=15\right.$ and $\left.\iota=1500 \mu \mathrm{mol} \mathrm{CO}_{2} \mathrm{~mol}^{-1} \mathrm{H}_{2} \mathrm{O}\right)$

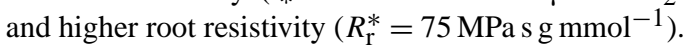

more gradual decline in leaf nitrogen, which is a function of $V_{\mathrm{c} \max 25}$ and based on observations across many forests (Lloyd et al., 2010).

The SPA-WUE stomatal optimization performs significantly better than the CLM-BB model at US-Me2, the site with the most significant soil moisture stress (Figs. 11, 13). In the stomatal optimization, soil moisture control of latent heat flux and GPP is an outcome of plant hydraulic constraints on leaf water-use efficiency optimization, whereas the similar dependence on soil moisture is specified in the CLMBB model by adjusting the intercept $\left(g_{0}\right)$ and $A_{\mathrm{n}}$ (through $\left.V_{\mathrm{cmax} 25}\right)$ for soil moisture using the soil wetness factor $\left(\beta_{t}\right)$. The exact form of this soil moisture stress function is 

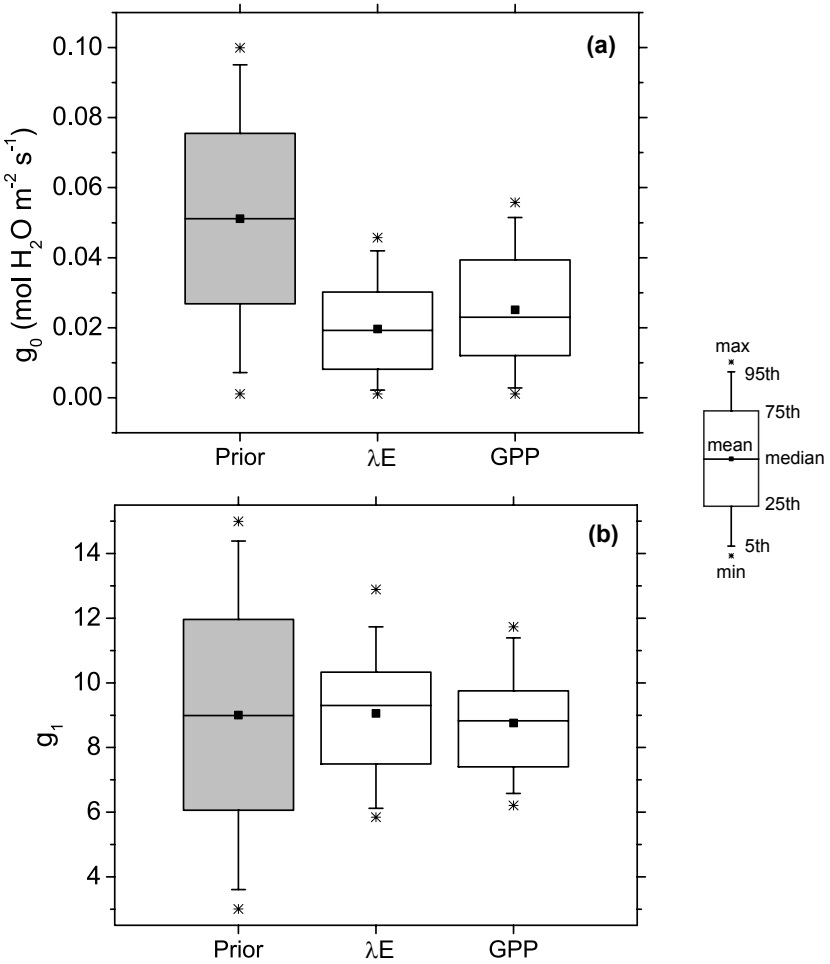

Figure 15. Parameter optimization of (a) $g_{0}$ and (b) $g_{1}$ for the CLM Ball-Berry model using flux data for US-Ha1 (July 2001). Shown are the distributions of prior parameter values from latin hypercube sampling ( $m=500$ points with $n=2$ variables) and the parameter values of the 50 simulations with the lowest root mean square error for latent heat flux $(\lambda E)$ and gross primary production (GPP). For the 50 simulations, RMSE $=37-41 \mathrm{~W} \mathrm{~m}^{-2}$ and 4.09 $4.15 \mu \mathrm{mol} \mathrm{CO} 2 \mathrm{~m}^{-2} \mathrm{~s}^{-1}$.

unknown, and other approaches adjust the slope $\left(g_{1}\right)$ (Egea et al., 2011; De Kauwe et al., 2013; Zhou et al., 2103). In our simulations, higher $\beta_{t}$ (less soil moisture stress) improves the CLM-BB model (Fig. 12), suggesting that the parameterization of soil moisture stress for this site, not the stomatal model per se, is erroneous. In contrast, the soil moisture stress emerges from the SPA optimization as a result of root uptake, water transport through the stem, internal water storage, and leaf water-use efficiency. Duursma and Medlyn (2012) also implemented the SPA plant hydraulics in the MAESTRA model, resulting in improvement for simulation of drought stress.

At sites without soil moisture stress, improvements with the SPA stomatal optimization are not as evident (Fig. 9). For deciduous broadleaf forests, the skill of latent heat flux and GPP compared with the CLM-BB model improves slightly at US-Ha1 and more so at US-MMS and US-UMB. All models perform comparably at US-Ho1, an evergreen needleleaf forest.

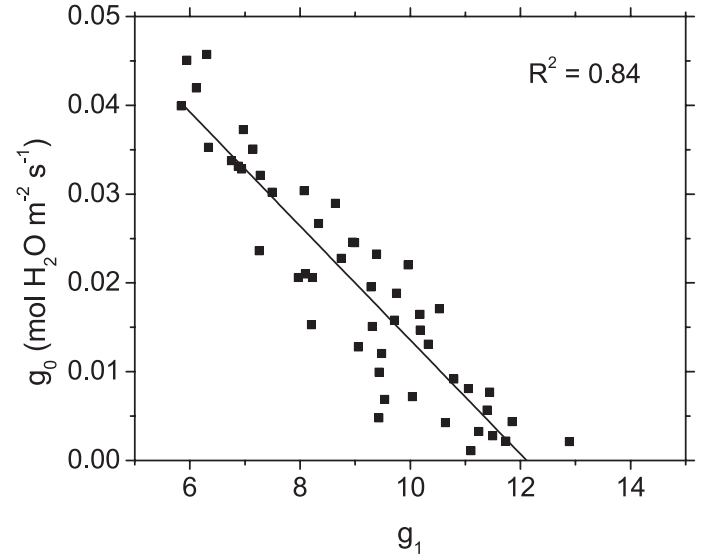

Figure 16. Relationship between $g_{0}$ and $g_{1}$ for the 50 simulations with the lowest root mean square error in latent heat flux. Data are from Fig. 15. Analysis of GPP errors shows a similar negative correlation (not shown).

Differences between intrinsic water-use efficiency optimization $\left(\Delta A_{\mathrm{n}} / \Delta g_{\mathrm{s}}\right)$ and water-use efficiency optimization $\left(\Delta A_{\mathrm{n}} / \Delta E_{1}\right)$ are generally not clear at the canopy scale (Fig. 9), but are evident in model skill at sites where there is moisture stress (e.g., US-Me2). Removal of the $\psi_{1 \text { min }}$ constraint on stomatal closure (which eliminates plant hydraulic control on stomatal functioning) degrades the $\Delta A_{\mathrm{n}} / \Delta g_{\mathrm{s}}$ optimization (which thereby lacks vapor pressure deficit regulation of stomatal conductance) more than the $\Delta A_{\mathrm{n}} / \Delta E_{1}$ optimization (with explicit vapor pressure deficit dependence).

The outcome of the two different stomatal optimizations is clearly depicted at the leaf scale. The relationship of $g_{\mathrm{s}}$ with vapor pressure deficit $\left(D_{\mathrm{s}}\right)$ emerges from the $\Delta A_{\mathrm{n}} / \Delta E_{1}$ optimization and does not require a priori relationships. It is notable that the water-use efficiency optimization directly predicts a relationship in which $g_{\mathrm{s}}$ varies in relation to $1-$ $0.5 \ln D_{\mathrm{s}}$ (Fig. 4), consistent with observations (Oren et al., 1999; Katul et al., 2009). Closed-form stomatal conductance models obtained from water-use efficiency optimization obtain a relationship with $D_{\mathrm{S}}^{-1 / 2}$ (Katul et al., 2009, 2010; Medlyn et al., 2011b), which approximates $1-0.5 \ln D_{\mathrm{s}}$.

A key parameter in the SPA water-use efficiency optimization is the stomatal efficiency $(\iota$, the marginal carbon gain of water loss). Maximum stomatal conductance and maximum photosynthetic rate have long been known to be correlated (Körner 1994; Hetherington and Woodward 2003), and coherent changes in photosynthetic carbon metabolism and stomatal behavior led to the understanding that they function in concert. The stomatal efficiency parameter determines the slope of the relationship between maximum $g_{\mathrm{s}}$ and $A_{\mathrm{n}}$ seen in such analyses (Fig. 5). Moreover, it relates closely to the slope ( $\left.g_{1}\right)$ of the Ball-Berry model (using $A_{\mathrm{n}} / c_{\mathrm{s}} h_{\mathrm{s}}$ ) and its variants (using $A_{\mathrm{n}} / c_{\mathrm{s}} D_{\mathrm{S}}^{-1 / 2}$ ) (Fig. 6). Medlyn et al. (2011b) showed that $g_{1}$ varies in relation to the square root of the 

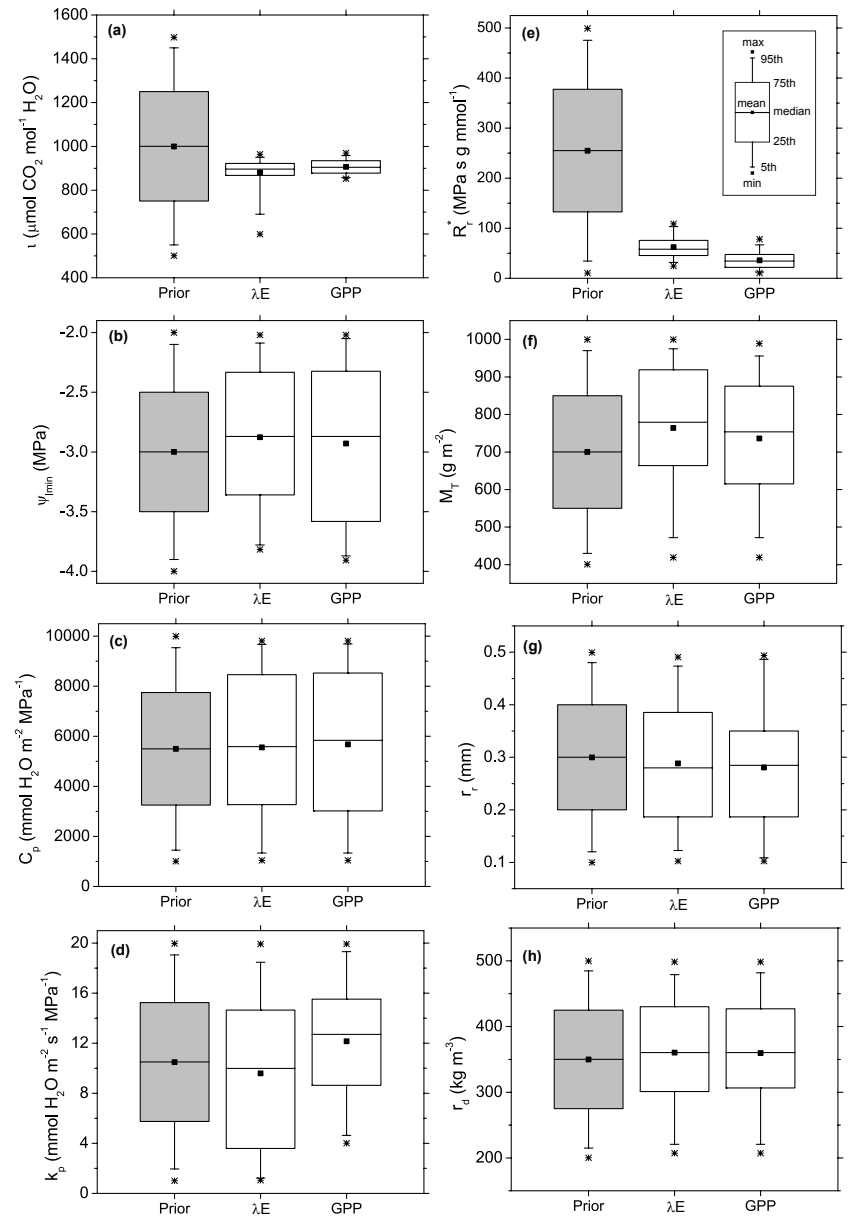

Figure 17. As in Fig. 15, but for SPA-WUE optimization. Parameters were generated from latin hypercube sampling ( $m=500$ points with $n=4$ variables). The left-hand panels (a-d) show prior and posterior values of the four aboveground stem and leaf parameters. The right-hand panels $(\mathbf{e}-\mathbf{h})$ show values of the four belowground root parameters. For simulations with the lowest $10 \%$ error, $\mathrm{RMSE}=35-37 \mathrm{~W} \mathrm{~m}^{-2}$ and $4.08-4.20 \mu \mathrm{mol} \mathrm{CO}_{2} \mathrm{~m}^{-2} \mathrm{~s}^{-1}$.

marginal water cost of carbon gain (the inverse of stomatal efficiency), and we similarly find that $g_{1}$ scales with $\iota^{-1 / 2}$. Medlyn et al. (2011b) also found that values for $g_{1}$ increase with growth temperature, are lower in gymnosperms than in angiosperms, and vary in relation to plant water-use strategy. Such variation also manifests in $\iota$, where we found that a higher value (more conservative water-use strategy) minimized model errors at the evergreen needleleaf forest USHo1 and US-Me2 compared with the lower value for deciduous broadleaf forest.

Two parameters ( $\iota$, stomatal efficiency; and $R_{\mathrm{r}}^{*}$, root hydraulic conductivity) minimized errors in the SPA wateruse efficiency stomatal optimization model (Fig. 18). Functional relationships among photosynthetic capacity, stomatal conductance, and plant hydraulics may help constrain these and other model parameters. For example, high stomatal
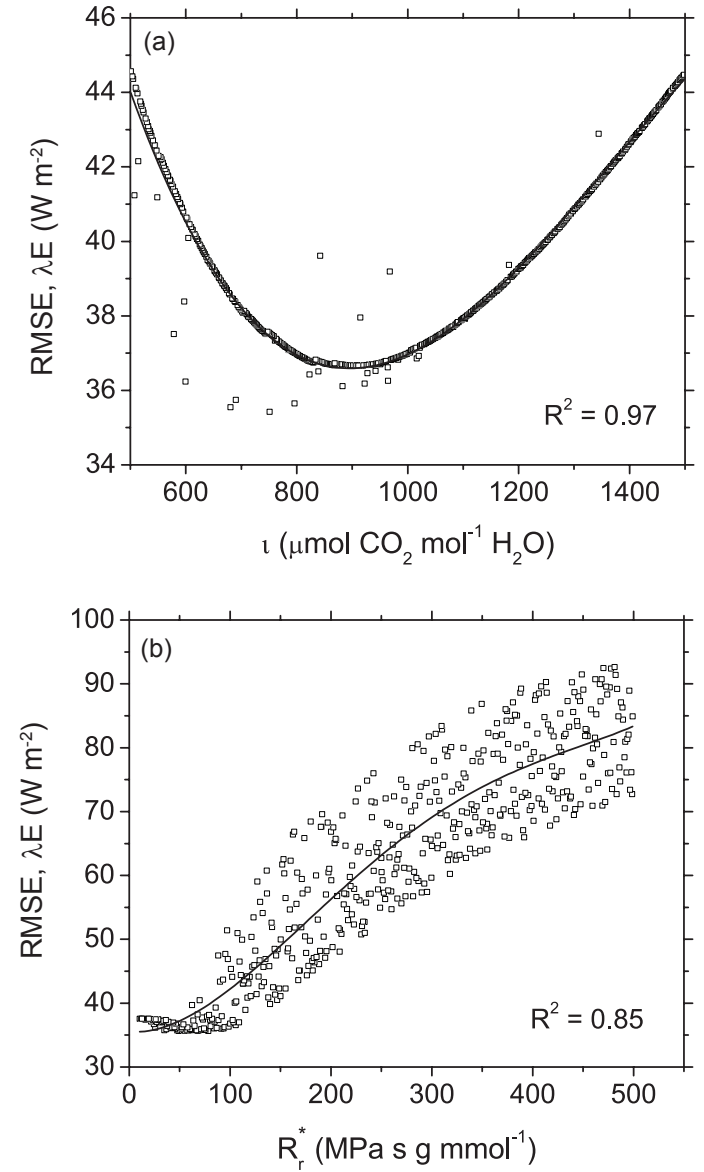

Figure 18. Root mean square error of latent heat flux from the latin hypercube sampling ( $m=500$ points) in relation to (a) $\iota$ and (b) $R_{\mathrm{r}}^{*}$ for US-Ha1 (July 2001) using SPA-WUE optimization. The solid lines show the polynomial regression. Analysis of GPP errors shows similar relationships (not shown).

efficiency or high root resistivity both improved simulations at US-Ho1 and US-Me2 (Fig. 14). In fact, it is likely that both traits co-vary with plant carbon-water economics. This suggests a need to include a concept of plant hydraulic architecture in the definition of functional types, noted also by Medlyn et al. (2011b). For example, minimum leaf water potential values are related to xylem function (Choat et al., 2012).

Our approach, as in the SPA model, numerically optimizes photosynthetic carbon gain per unit water loss while also avoiding desiccation by preventing low leaf water potential. Alternatively, Ball-Berry style stomatal conductance models provide a closed-form analytical equation for stomatal functioning and can be combined with an empirical dependence on soil moisture or leaf water potential (Tuzet et al., 2003; Duursma and Medlyn, 2012; Zhou et al., 2013). Some computational cost is added by the numerics of the stomatal optimization. However, the greater computational cost (and also the benefit) of the model presented here, relative to 
CLM4.5, is in resolving gradients within the canopy. Bonan et al. (2012) showed that inexactness in the absorption of diffuse radiation by shaded leaves leads to errors in GPP for a sunlit/shaded big-leaf canopy model relative to a multi-layer canopy model. This error can be decreased with high values for the nitrogen decay coefficient $\left(K_{\mathrm{n}}\right)$, but such values are inconsistent with field estimates (Lloyd et al., 2010). A similar inexactness arises due to gradients of leaf water potential within the canopy. One of the predictions of the SPA stomatal optimization is that leaves in the upper canopy, with high solar radiation and high transpiration rates, close their stomata to avoid desiccation. Non-linear gradients of light, nitrogen, and leaf water potential must be accounted for when formulating theories of canopy optimization (Peltoniemi et al., 2012). Just as multi-layer profiles of soil carbon are being recognized as important for carbon cycle-climate feedbacks (Koven et al., 2013), profiles in the plant canopy may similarly be important for vegetation-atmosphere coupling. Here, we resolve the canopy leaf area profile at high resolution (increments of $0.1 \mathrm{~m}^{2} \mathrm{~m}^{-2}$ for leaf area index of $\left.\sim 4-5\right)$. Other SPA simulations successfully divide the canopy into fewer layers (e.g., 10 layers for a canopy with a leaf area index of $3.5 \mathrm{~m}^{2} \mathrm{~m}^{-2}$, Williams et al., 1996).

\section{Conclusions}

Stomatal control of energy, water, and $\mathrm{CO}_{2}$ fluxes is a key component of vegetation-atmosphere coupling in earth system models. Here, we outline a framework for modeling stomatal conductance that is new to earth system models. This framework links leaf gas exchange, plant hydraulic constraints, and the soil-plant-atmosphere continuum to optimize photosynthetic carbon gain per unit water loss while also avoiding desiccation through low leaf water potential. Thus, we extend the water-use efficiency hypothesis inherent in the Ball-Berry stomatal model (Katul et al., 2010; Medlyn et al., 2011b) with a model that also considers whether the rates of water transport and water use are physiologically plausible. The two concepts, that plants account for both water-use efficiency and for hydraulic safety in their stomatal regulatory physiology, imply a notion of optimal plant strategies, and thus provide testable model hypotheses, rather than empirical descriptions of plant behavior. Two key parameters in the model are obtainable from leaf gas exchange measurements $(\iota)$ and root physiological measurements $\left(R_{\mathrm{r}}^{*}\right)$, as are other plant parameters (e.g., $\psi_{1 \text { min }}$ and $k_{\mathrm{p}}$ ). Moreover, the mechanistic basis of the model predictions can be assessed using observations of leaf water potential $\left(\psi_{1}\right)$ and plant conductance $\left(k_{\mathrm{L}}\right)$ (e.g., Fisher et al., 2006, 2007).
Credible simulations of land-atmosphere feedbacks in earth system models require that models be characterized in terms of process parameterizations and assumptions in order to correctly interpret the projections of a future earth (Medlyn et al., 2011a). The development and evaluation of the land component of earth system models must embrace a synergy of ecological observations (herein, leaf and canopy fluxes), theory to explain the observations (herein, plant carbonwater economics), numerical parameterizations to mathematically describe that theory, and simulations to evaluate the parameterizations across scales, from leaf to canopy, and ultimately global. The model described here represents a necessary approach to rigorously and comprehensively evaluate process parameterizations for consistency with observations and theory prior to implementation in a full earth system model. However, the framework still must be extended to herbaceous plants (grasses and crops) and proven for $\mathrm{C}_{4}$ plants before it can be implemented in a global model. The model code is available at http://www.cgd.ucar.edu/staff/ bonan/. 


\section{Appendix A: Model description}

\section{A1 Canopy structure and photosynthetic capacity}

The canopy is divided into $n$ layers each with leaf area index $\Delta L=0.1 \mathrm{~m}^{2} \mathrm{~m}^{-2}$. The leaf area is evenly distributed between the canopy top and bottom heights. Foliage nitrogen and photosynthetic capacity are distributed with depth in the canopy (Bonan et al., 2012). Foliage nitrogen concentration (per unit leaf area) declines exponentially with greater cumulative leaf area from the canopy top, defined by a decay coefficient $\left(K_{\mathrm{n}}\right)$. Photosynthetic parameters at $25^{\circ} \mathrm{C}\left(V_{\mathrm{c} \max 25}\right.$, $J_{\max 25}$, and $\left.R_{\mathrm{d} 25}\right)$ scale directly with leaf nitrogen and similarly decrease with depth in the canopy. $V_{\mathrm{c} \max 25}$ at cumulative leaf area index $x$ from the canopy top is given by

$V_{\mathrm{c} \max 25}(x)=V_{\mathrm{c} \max 25}(0) e^{-K_{\mathrm{n}} x}$,

where $V_{\mathrm{cmax} 25}(0)$ is defined at the top of the canopy. $K_{\mathrm{n}}$ scales with $V_{\mathrm{c} \max 25}$ at the canopy top following Lloyd et al. (2010)

$K_{\mathrm{n}}=\exp \left(0.00963 V_{\mathrm{c} \max 25}-2.43\right)$.

Values for additional photosynthetic metabolic parameters are proportional to $V_{\mathrm{cmax} 25}$, given by $J_{\max 25}=1.67 V_{\mathrm{c} \max 25}$ and $R_{\mathrm{d} 25}=0.015 V_{\mathrm{c} \max 25}$. The ratio $J_{\max 25} / V_{\mathrm{c} \max 25}$ varies with temperature acclimation (Kattge and Knorr, 2007).

\section{A2 Radiative transfer}

Radiative transfer is calculated from Norman (1979) for visible, near-infrared, and longwave radiation, similar to CANVEG and SPA, and accounts for scattering within the canopy based on leaf reflectance $\left(\rho_{1}\right)$, transmittance $\left(\tau_{1}\right)$, and leaf orientation $\left(\chi_{1}\right)$ (Fig. 1a). Solar radiation incident on the canopy is partitioned as $50 \%$ visible and $50 \%$ near-infrared. The two shortwave bands are divided into direct and diffuse streams, as in CLM4.5. The canopy is partitioned into sunlit and shaded fractions at each layer, with the sunlit faction given by

$f_{\text {sun }}(x)=e^{-K_{\mathrm{b}} x}$,

where $K_{\mathrm{b}}$ is the extinction coefficient for direct beam. Shaded leaves receive only diffuse radiation, while sunlit leaves receive diffuse and direct beam radiation. Soil albedo is calculated as in CLM4.5 and varies with soil color class and water content of the first soil layer. Leaf emissivity is $\varepsilon_{1}=0.98$, and soil emissivity is $\varepsilon_{g}=0.96$.

\section{A3 Leaf model}

\section{A3.1 Leaf temperature and energy balance}

The leaf model couples photosynthesis, stomatal conductance, leaf temperature, and the leaf energy balance at each layer in the canopy (Fig. 1b). Sensible heat $\left(H_{1}, \mathrm{~W} \mathrm{~m}^{-2}\right)$ is exchanged between the leaf with temperature $T_{1}(\mathrm{~K})$ and canopy air with temperature $T_{\mathrm{a}}(\mathrm{K})$

$H_{1}=2 c_{p}\left(T_{1}-T_{\mathrm{a}}\right) g_{\mathrm{bh}}$,

where $c_{p}$ is the specific heat of air at constant pressure $\left(\mathrm{J} \mathrm{mol}^{-1} \mathrm{~K}^{-1}\right)$ and $g_{\mathrm{bh}}$ is the leaf boundary layer conductance for heat $\left(\mathrm{mol} \mathrm{m}^{-2} \mathrm{~s}^{-1}\right)$. Latent heat flux $\left(\lambda E_{1}, \mathrm{~W} \mathrm{~m}^{-2}\right)$ is linearized about saturation vapor pressure

$\lambda E_{1}=\frac{c_{p}}{\gamma}\left[e_{*}\left(T_{\mathrm{a}}\right)+s\left(T_{1}-T_{\mathrm{a}}\right)-e_{\mathrm{a}}\right] /\left(g_{\mathrm{s}}^{-1}+g_{\mathrm{bv}}^{-1}\right)$.

Here, $e_{*}\left(T_{\mathrm{a}}\right)$ is the saturation vapor pressure $(\mathrm{Pa})$ at air temperature, $e_{\mathrm{a}}$ is the vapor pressure ( $\mathrm{Pa}$ ) within the canopy, and $s\left(\mathrm{~Pa} \mathrm{~K}^{-1}\right)$ is the slope of the saturation vapor pressure function with respect to temperature. The term $\gamma=$ $c_{p} P_{\text {ref }} / \lambda$ is the psychrometric constant $\left(\mathrm{Pa} \mathrm{K}^{-1}\right)$, with $P_{\text {ref }}$ atmospheric pressure $(\mathrm{Pa})$ and $\lambda$ latent heat of vaporization $\left(\mathrm{J} \mathrm{mol}^{-1}\right)$. The term $g_{\mathrm{v}}=1 /\left(g_{\mathrm{s}}^{-1}+g_{\text {bv }}^{-1}\right)$ is the total leaf conductance for water vapor $\left(\mathrm{mol} \mathrm{m}^{-2} \mathrm{~s}^{-1}\right)$ from stomata $\left(g_{\mathrm{s}}\right)$ and the leaf boundary layer $\left(g_{\text {bv }}\right)$ in series. Leaf temperature is calculated from the energy balance equation

$R_{\mathrm{nl}}=H_{1}+\lambda E_{1}$

and

$T_{1}-T_{\mathrm{a}}=\frac{R_{\mathrm{nl}}-\frac{c_{p}}{\gamma}\left[e_{*}\left(T_{\mathrm{a}}\right)-e_{\mathrm{a}}\right] g_{\mathrm{v}}}{2 c_{p} g_{\mathrm{bh}}+\frac{c_{p}}{\gamma} s g_{\mathrm{v}}}$,

with $R_{\mathrm{nl}}$ the net radiation for the canopy layer. Leaf boundary layer conductances ( $g_{\text {bh }}$ and $g_{\text {bv }}$ ) vary with leaf dimension $\left(d_{1}, \mathrm{~m}\right)$ and wind speed $\left(u_{\mathrm{a}}, \mathrm{m} \mathrm{s}^{-1}\right)$. For heat

$g_{\text {bh }}=a\left(u_{\mathrm{a}} / d_{1}\right)^{0.5}$

and for water vapor

$\frac{g_{\text {bv }}}{g_{\text {bh }}}=\left(\frac{D_{\mathrm{v}}}{D_{\mathrm{h}}}\right)^{0.67}$.

The coefficient $a$ varies with temperature. A representative value is $a=0.2 \mathrm{~mol} \mathrm{~m}^{-2} \mathrm{~s}^{-1 / 2}$ at $20^{\circ} \mathrm{C}$. The thermal diffusivity of air $\left(D_{\mathrm{h}}, \mathrm{m}^{2} \mathrm{~s}^{-1}\right)$ and molecular diffusivity of $\mathrm{H}_{2} \mathrm{O}$ $\left(D_{\mathrm{v}}, \mathrm{m}^{2} \mathrm{~s}^{-1}\right)$ vary with temperature and pressure. At $20^{\circ} \mathrm{C}$ and sea level, $D_{\mathrm{v}} / D_{\mathrm{h}}=1.15$. With $d_{1}=0.04 \mathrm{~m}, g_{\mathrm{bh}}=1.4$ and $g_{\mathrm{bv}}=1.5 \mathrm{~mol} \mathrm{~m}^{-2} \mathrm{~s}^{-1}$ for a wind speed of $2 \mathrm{~m} \mathrm{~s}^{-1}$.

\section{A3.2 Photosynthesis}

Leaf carbon assimilation is calculated as in CLM4.5, using the Farquhar et al. (1980) photosynthesis model described by Bonan et al. (2011, 2012), with the addition of temperature acclimation (Kattge and Knorr, 2007). Net leaf $\mathrm{CO}_{2}$ assimilation $\left(A_{\mathrm{n}}, \mu \mathrm{mol} \mathrm{CO} \mathrm{Cm}^{-2} \mathrm{~s}^{-1}\right)$ is the lesser of two rates

$A_{\mathrm{n}}=\min \left(A_{\mathrm{c}}, A_{j}\right)-R_{\mathrm{d}}$, 
where the rubisco-limited rate is

$A_{\mathrm{c}}=\frac{V_{\mathrm{c} \max }\left(c_{\mathrm{i}}-\Gamma_{*}\right)}{c_{\mathrm{i}}+K_{\mathrm{c}}\left(1+o_{i} / K_{\mathrm{o}}\right)}$

and the RuBP-limited rate is

$A_{j}=\frac{J\left(c_{\mathrm{i}}-\Gamma_{*}\right)}{4 c_{\mathrm{i}}+8 \Gamma_{*}}$

In these equations, $c_{\mathrm{i}}\left(\mu \mathrm{mol} \mathrm{mol}{ }^{-1}\right)$ is the intercellular $\mathrm{CO}_{2}, \Gamma_{*}\left(\mu \mathrm{mol} \mathrm{mol}{ }^{-1}\right)$ is the $\mathrm{CO}_{2}$ compensation point, $K_{\mathrm{c}}$ $\left(\mu \mathrm{mol} \mathrm{mol}^{-1}\right)$ and $K_{\mathrm{o}}\left(\mathrm{mmol} \mathrm{mol}^{-1}\right)$ are the MichaelisMenten constants, and $o_{i}=209 \mathrm{mmol} \mathrm{mol}^{-1}$ is the $\mathrm{O}_{2}$ concentration. The electron transport rate $\left(J, \mu \mathrm{mol} \mathrm{m}^{-2} \mathrm{~s}^{-1}\right)$ varies with absorbed photosynthetically active radiation with a maximum rate $J_{\max }$. The maximum rate of carboxylation $\left(V_{\mathrm{c} \max }, \mu \mathrm{mol} \mathrm{m} \mathrm{m}^{-2} \mathrm{~s}^{-1}\right)$, maximum rate of electron transport $\left(J_{\max }, \mu \mathrm{mol} \mathrm{m} \mathrm{m}^{-2} \mathrm{~s}^{-1}\right)$, and leaf respiration rate $\left(R_{\mathrm{d}}\right.$, $\left.\mu \mathrm{mol} \mathrm{m} \mathrm{m}^{-2} \mathrm{~s}^{-1}\right)$ vary with leaf temperature using temperature acclimation (Kattge and Knorr, 2007). Values at $25^{\circ} \mathrm{C}$ scale directly with leaf nitrogen concentration according to Eq. (A1). The parameters $\Gamma_{*}, K_{\mathrm{c}}$, and $K_{\mathrm{o}}$ also vary with leaf temperature.

\section{A3.3 Stomatal conductance}

The Ball-Berry stomatal conductance model (Ball et al., 1987; Collatz et al., 1991) is

$g_{\mathrm{s}}=g_{0}+g_{1} A_{\mathrm{n}} \frac{h_{\mathrm{s}}}{c_{\mathrm{S}}}$,

where $g_{0}$ is the minimum conductance $\left(\mathrm{mol} \mathrm{m}^{-2} \mathrm{~s}^{-1}\right), g_{1}$ is the slope parameter, $h_{\mathrm{s}}$ is the fractional relative humidity at the leaf surface, and $c_{\mathrm{S}}\left(\mu \mathrm{mol} \mathrm{mol}{ }^{-1}\right)$ is the leaf surface $\mathrm{CO}_{2}$ concentration. The system of equations is solved for the $c_{\mathrm{i}}$ that balances the metabolic assimilation rate, given by Eq. (A10), and the diffusive rate given by

$$
\begin{aligned}
& A_{\mathrm{n}}=\frac{g_{\mathrm{bv}}}{1.4}\left(c_{\mathrm{a}}-c_{\mathrm{s}}\right)=\frac{g_{\mathrm{s}}}{1.6}\left(c_{\mathrm{s}}-c_{\mathrm{i}}\right) \\
& =\frac{\left(c_{\mathrm{a}}-c_{\mathrm{i}}\right)}{1.4 g_{\mathrm{bv}}^{-1}+1.6 g_{\mathrm{s}}^{-1}},
\end{aligned}
$$

with $c_{\mathrm{a}}$ the $\mathrm{CO}_{2}$ concentration of air $\left(\mu \mathrm{mol} \mathrm{mol}{ }^{-1}\right)$. Because the metabolic parameters $\left(V_{\mathrm{c} \max }, J_{\max }, R_{\mathrm{d}}, \Gamma_{*}, K_{\mathrm{c}}\right.$ and $\left.K_{\mathrm{o}}\right)$ that govern assimilation depend on leaf temperature, the entire calculation is iterated until leaf temperature converges within some specified tolerance (Fig. 2a).

In this implementation, as in CLM4.5, soil water influences stomatal conductance directly by multiplying $g_{0}$ by a soil moisture stress function $\beta_{t}$ (with values $0-1$ ) and also indirectly by multiplying $V_{\mathrm{c}}$ max by $\beta_{t}$. Soil moisture stress is calculated for each soil layer and summed, weighted by the relative root fraction of the soil layer $\left(\Delta f_{j}\right)$. For unfrozen soil

$\beta_{t}=\sum_{j} \frac{\psi_{\mathrm{c}}-\psi_{\mathrm{s}, j}}{\psi_{\mathrm{c}}-\psi_{o}} \Delta f_{j}$ where $\psi_{\mathrm{s}, j}$ is the soil water potential of layer $j$, and $\psi_{\mathrm{c}}$ and $\psi_{\mathrm{o}}$ are the soil water potential at which stomata are fully closed or open, respectively.

The stomatal optimization calculates $g_{\mathrm{s}}$ for each canopy layer to maximize $A_{\mathrm{n}}$ within limitations imposed by wateruse efficiency, plant water storage, and soil-to-leaf water transport (Fig. 2b). Stomata conductance is calculated such that (1) further opening does not yield a sufficient carbon gain per unit water loss (defined by a stomatal efficiency parameter) or (2) further opening causes leaf water potential to decrease below the minimum sustainable leaf water potential that prevents xylem cavitation (defined by the parameter $\left.\psi_{1 \mathrm{~min}}\right)$. In the latter case, the minimum stomatal conductance is $2 \mathrm{mmol} \mathrm{H}_{2} \mathrm{O} \mathrm{m}^{-2} \mathrm{~s}^{-1}$.

We tested two alternative definitions of stomatal efficiency: $\iota_{*}$, based on intrinsic water-use efficiency (iWUE; $\Delta A_{\mathrm{n}} / \Delta g_{\mathrm{s}}$ ); and $\iota$, based on water-use efficiency (WUE; $\left.\Delta A_{\mathrm{n}} / \Delta E_{1}\right)$. Both optimizations require that $\psi_{1}>\psi_{1 \mathrm{~min}}$. The $g_{\mathrm{s}}$ that satisfies these constraints is obtained numerically by solving the system of equations twice, once for $g_{\mathrm{s}}-\Delta g_{\mathrm{s}}$ and again for $g_{\mathrm{s}}$, where $\Delta g_{\mathrm{s}}=1 \mathrm{mmol} \mathrm{H}_{2} \mathrm{Om}^{-2} \mathrm{~s}^{-1}$ (Fig. 2b). This provides $\Delta A_{\mathrm{n}}$ in relation to a small increment $\Delta g_{\mathrm{s}}$. Leaf transpiration is

$E_{1}=\frac{\left(e_{i}-e_{\mathrm{s}}\right)}{P_{\mathrm{ref}}} g_{\mathrm{s}}=D_{\mathrm{s}} g_{\mathrm{s}}$,

where $D_{\mathrm{s}}=\left(e_{i}-e_{\mathrm{S}}\right) / P_{\text {ref }}$ is the vapor pressure deficit at the leaf surface $\left(\mathrm{mol} \mathrm{mol}^{-1}\right)$ and $e_{i}=e_{*}\left(T_{1}\right)$ is the vapor pressure in the stomatal cavity. For a small increment in stomatal conductance $\left(\Delta g_{\mathrm{s}}\right)$, the change in transpiration is

$\Delta E_{1}=D_{\mathrm{s}} \Delta g_{\mathrm{s}}$,

assuming that $D_{\mathrm{s}}$ is constant over $\Delta g_{\mathrm{s}}$. Then

$\frac{\Delta A_{\mathrm{n}}}{\Delta E_{\mathrm{l}}}=\frac{\Delta A_{\mathrm{n}}}{\Delta g_{\mathrm{s}}} \frac{1}{D_{\mathrm{s}}}$.

For iWUE optimization, $g_{\mathrm{s}}$ is calculated so that a small increment $\left(\Delta g_{\mathrm{s}}=1 \mathrm{mmol} \mathrm{H}_{2} \mathrm{O} \mathrm{m}^{-2} \mathrm{~s}^{-1}\right)$ changes leaf assimilation by $\Delta A_{\mathrm{n}} \leq \iota_{*} \Delta g_{\mathrm{s}}$ with the constraint that $\psi_{1}>$ $\psi_{1 \text { min }}$. The same procedure applies to WUE optimization, but with $\Delta A_{\mathrm{n}} \leq \imath D_{\mathrm{s}} \Delta g_{\mathrm{s}}$. Numerical techniques (Brent's method, which combines bisection and inverse quadratic interpolation) are used to efficiently solve for $g_{\mathrm{s}}$.

\section{A4 Plant hydraulics}

\section{A4.1 Leaf water potential}

The change in leaf water potential $\left(\psi_{1}, \mathrm{MPa}\right)$ of each canopy layer is governed by the equation

$\frac{\mathrm{d} \psi_{1}}{\mathrm{~d} t}=\frac{k_{\mathrm{L}}\left(\bar{\psi}_{\mathrm{s}}-\rho_{\mathrm{w}} g h 10^{-6}\right)-1000 E_{1}-k_{\mathrm{L}} \psi_{1}}{C_{\mathrm{p}}}$,

where $\bar{\psi}_{\mathrm{s}}$ is soil water potential (MPa), and $\rho_{\mathrm{w}} g h 10^{-6}$ is the gravitational potential (MPa) for a water column with 
height $h(\mathrm{~m})$, density $\rho_{\mathrm{w}}\left(\mathrm{kg} \mathrm{m}^{-3}\right)$, and gravitational acceleration $g\left(\mathrm{~m} \mathrm{~s}^{-2}\right) . k_{\mathrm{L}}$ is the hydraulic conductance of the soil-to-leaf pathway per unit leaf area (leaf-specific conductance, $\mathrm{mmol} \mathrm{H}_{2} \mathrm{O} \mathrm{m}^{-2}$ leaf area s$\left.{ }^{-1} \mathrm{MPa}^{-1}\right)$, composed of a belowground $\left(R_{\mathrm{b}}\right)$ and aboveground plant $\left(R_{\mathrm{a}}\right)$ resistance (MPa s m${ }^{2}$ leaf area $\mathrm{mmol}^{-1} \mathrm{H}_{2} \mathrm{O}$ ) in series. $1000 E_{1}$ is the transpiration loss for the layer $\left(\mathrm{mmol} \mathrm{H}_{2} \mathrm{O} \mathrm{m}^{-2}\right.$ leaf area s$\left.{ }^{-1}\right) . C_{\mathrm{p}}$ is plant capacitance $\left(\mathrm{mmol} \mathrm{H}_{2} \mathrm{O} \mathrm{m}^{-2}\right.$ leaf area $\left.\mathrm{MPa}^{-1}\right)$, defined as the ratio of the change in plant water content to the change in water potential. Equation (A19) is solved for each canopy layer. The change in leaf water potential over a model time step $(\Delta t, \mathrm{~s})$ is

$\Delta \psi_{1}=\left(a-\psi_{0}\right)\left(1-e^{-\Delta t / b}\right)$,

where $\psi_{0}$ is the leaf water potential at the beginning of the time step, $a=\bar{\psi}_{\mathrm{s}}-\rho_{\mathrm{w}} g h 10^{-6}-1000 E_{\mathrm{l}} / k_{\mathrm{L}}$, and $b=C_{\mathrm{p}} / k_{\mathrm{L}}$.

\section{A4.2 Leaf-specific hydraulic conductance}

The leaf-specific hydraulic conductance of the soil-to-leaf pathway integrates the hydraulic conductance of roots, stems, and branches and is given by a belowground $\left(R_{\mathrm{b}}\right)$ and aboveground plant $\left(R_{\mathrm{a}}\right)$ resistance in series

$$
\frac{1}{k_{\mathrm{L}}}=R_{\mathrm{b}}+R_{\mathrm{a}} \text {. }
$$

The aboveground plant resistance governing flow through stems to leaves is

$$
R_{\mathrm{a}}=\frac{1}{k_{\mathrm{p}}}
$$

where $k_{\mathrm{p}}\left(\mathrm{mmol} \mathrm{H}_{2} \mathrm{O} \mathrm{m}^{-2}\right.$ leaf area s$\left.{ }^{-1} \mathrm{MPa}^{-1}\right)$ is the leafspecific stem hydraulic conductance (i.e., the stem-to-leaf path).

The belowground resistance is the resistance to water uptake imposed by water movement in the soil and by fine roots ( $\leq 2 \mathrm{~mm}$ diameter). It is represented by multiple soil layers connected in parallel with a soil-to-root conductance $\left(k_{\mathrm{s}}\right)$ and a root-to-stem conductance $\left(k_{\mathrm{r}}\right)$ within each layer (Fig. 1c), as described by Williams et al. (2001a). The conductance of the soil-to-root path is based on Williams et al. (2001a), used also in MAESPA (Duursma and Medlyn, 2012), which builds upon the theoretical framework of Gardner (1960) and Newman (1969). For soil layer $j$, it depends on the soil hydraulic conductivity of the layer $\left(G_{j}, \mathrm{mmol} \mathrm{H}_{2} \mathrm{O} \mathrm{m}^{-1} \mathrm{~s}^{-1} \mathrm{MPa}^{-1}\right)$, which varies with soil water content and texture, and the characteristics of the rooting system given by the equation

$$
k_{\mathrm{s}, j}=\frac{2 \pi L_{\mathrm{r}, j} \Delta z_{j} G_{j}}{\ln \left(r_{\mathrm{s}, j} / r_{\mathrm{r}}\right)},
$$

where $L_{\mathrm{r}, j}$ is the root length per unit volume of soil (root length density, $\left.\mathrm{m} \mathrm{m}^{-3}\right), L_{\mathrm{r}, j} \Delta z_{j}$ is the root length per unit area of soil (root length index, $\mathrm{m} \mathrm{m}^{-2}$ ) in a layer with thickness $\Delta z_{j}(\mathrm{~m})$, and $r_{\mathrm{r}}$ is the mean fine root radius (m). The term $r_{\mathrm{s}, j}=\left(\pi L_{\mathrm{r}, j}\right)^{-1 / 2}$ is one-half the distance between roots (m), calculated with the assumption of uniform root spacing and assuming the soil is divided into cylinders with the root along the middle axis. The conductance of the root-to-stem path is calculated from root resistivity $\left(R_{\mathrm{r}}^{*}\right.$, MPa s $\mathrm{mmol}^{-1} \mathrm{H}_{2} \mathrm{O}$ ) and root biomass per unit soil volume $\left(M_{\mathrm{r}, j}\right.$, root biomass density, $\left.\mathrm{g} \mathrm{m}^{-3}\right)$,

$k_{\mathrm{r}, j}=\frac{M_{\mathrm{r}, j} \Delta z_{j}}{R_{\mathrm{r}}^{*}}$.

The total belowground resistance is obtained assuming the layers are arranged in parallel

$$
R_{\mathrm{b}}=\left(\sum_{j} \frac{1}{k_{\mathrm{s}, j}^{-1}+k_{\mathrm{r}, j}^{-1}}\right)^{-1} L_{T} .
$$

Multiplication of the belowground resistance by the canopy leaf area index $\left(L_{T}\right)$ arises because the belowground resistance is calculated on a ground area basis; multiplying by $L_{T}$ converts to leaf area. This assumes that each canopy layer is connected to each soil layer, so that the roots in each soil layer supply water to each canopy layer, and that the fraction of roots supplying each canopy layer is the same as the leaf area in that layer. In a wet soil, soil hydraulic conductivity is large, and most of the belowground resistance is from the roots $\left(k_{\mathrm{r}}\right)$. As the soil becomes drier, hydraulic conductivity decreases and $k_{\mathrm{s}}$ contributes more to the total resistance.

The total canopy transpiration can be partitioned to each soil layer. The maximum water uptake rate for a soil layer is determined by the difference between soil water potential $\left(\psi_{\mathrm{s}, j}, \mathrm{MPa}\right)$ and the minimum leaf water potential

$E_{\max , j}=\frac{\psi_{\mathrm{s}, j}-\psi_{1 \mathrm{~min}}}{k_{\mathrm{s}, j}^{-1}+k_{\mathrm{r}, j}^{-1}}$

The fraction of transpiration supplied by an individual soil layer is

$$
f_{\mathrm{t}, j}=E_{\max , j} / \sum_{j} E_{\max , j}
$$

and the weighted soil water potential for Eq. (A19) is

$\bar{\psi}_{\mathrm{s}}=\sum_{j} \psi_{\mathrm{s}, j} f_{\mathrm{t}, j}$.

\section{A5 Root profile}

The root system is described by live fine root biomass $\left(M_{T}, \mathrm{~g} \mathrm{~m}^{-2}\right)$ and its distribution with depth in the soil. The root biomass density $\left(M_{\mathrm{r}, j}\right.$, root biomass per unit soil volume, $\left.\mathrm{g} \mathrm{m}^{-3}\right)$ in a soil layer $\Delta z_{j}(\mathrm{~m})$ thick that contains $\Delta f_{j}$ of the total root biomass (specified as in CLM4.5 using the 
root distribution parameters $r_{\mathrm{a}}$ and $r_{\mathrm{b}}$; Oleson et al., 2013) is

$M_{\mathrm{r}, j}=M_{T} \Delta f_{j} / \Delta z_{j}$.

The root length density $\left(L_{\mathrm{r}, j}\right.$, root length per unit volume of soil, $\mathrm{m} \mathrm{m}^{-3}$ ) is

$L_{\mathrm{r}, j}=\frac{M_{\mathrm{r}, j}}{r_{\mathrm{d}} \pi r_{\mathrm{r}}^{2}}$,

where $r_{\mathrm{d}}$ is the specific root density ( $\mathrm{g}$ biomass per $\mathrm{m}^{3}$ root) and $\pi r_{\mathrm{r}}^{2}$ is the root cross-sectional area $\left(\mathrm{m}^{2}\right)$ calculated from mean fine root radius $\left(r_{\mathrm{r}}, \mathrm{m}\right)$.

\section{A6 Soil temperature and energy balance}

The ground surface temperature is the temperature that balances the net radiation, sensible heat flux, latent heat flux, and soil heat flux at the soil surface

$R_{\text {ng }}=H_{\mathrm{g}}+\lambda E_{\mathrm{g}}+G_{\text {soil }}$.

Net radiation $\left(R_{\mathrm{ng}}\right)$ at the soil surface is calculated as part of the canopy radiative transfer. Sensible heat is exchanged between the soil surface with temperature $T_{\mathrm{g}}(\mathrm{K})$ and canopy air with temperature $T_{\mathrm{a}}(\mathrm{K})$

$H_{\mathrm{g}}=c_{p}\left(T_{\mathrm{g}}-T_{\mathrm{a}}\right) g_{\mathrm{ah}}^{\prime}$,

where $g_{\mathrm{ah}}^{\prime}$ is the aerodynamic conductance within the canopy $\left(\mathrm{mol} \mathrm{m}{ }^{-2} \mathrm{~s}^{-1}\right)$. Latent heat flux is similarly exchanged between the soil surface and canopy $\left(e_{\mathrm{a}}\right)$

$\lambda E_{\mathrm{g}}=\frac{c_{p}}{\gamma}\left[h_{g} e_{*}\left(T_{\mathrm{g}}\right)-e_{\mathrm{a}}\right] g_{\mathrm{v}}$,

where $h_{g}=\exp \left[g M_{\mathrm{w}} \psi_{\mathrm{s} 1} /\left(\Re T_{\mathrm{s} 1}\right)\right]$ is the fractional humidity at the soil surface, with $g$ gravitational acceleration $\left(\mathrm{m} \mathrm{s}^{-2}\right)$, $M_{\mathrm{w}}$ the molecular mass of water $\left(\mathrm{kg} \mathrm{mol}^{-1}\right), \Re$ the universal gas constant $\left(\mathrm{J} \mathrm{K}^{-1} \mathrm{~mol}^{-1}\right), \psi_{\mathrm{s} 1}$ the matric potential of the first soil layer (here in meters), and $T_{\mathrm{s} 1}$ the temperature of the first soil layer (K). $g_{\mathrm{v}}=1 /\left(g_{\text {soil }}^{-1}+g^{\prime-1}\right.$ ah $)$ is the total conductance for water vapor $\left(\mathrm{mol} \mathrm{H}_{2} \mathrm{O} \mathrm{m}^{-2} \mathrm{~s}^{-1}\right)$ from the soil surface $\left(g_{\text {soil }}\right)$ and within-canopy aerodynamics $\left(g_{\text {ah }}^{\prime}\right)$ in series. In this study, $g_{\text {soil }}=0.002 \hat{\rho}$, where $\hat{\rho}=P_{\text {ref }} / \mathfrak{R} T_{\text {ref }}$ is the molar density $\left(\mathrm{mol} \mathrm{m}^{-3}\right)$; i.e., the surface resistance is $500 \mathrm{~s} \mathrm{~m}^{-1}$. This formulation of surface fluxes is based on CLM4.5, but additionally uses a ground surface conductance $\left(g_{\text {soil }}\right)$ to represent the effects of diffusion constraints on soil evaporation.

The soil heat flux between the surface and the first soil layer with temperature $T_{\mathrm{s} 1}(\mathrm{~K})$, thermal conductivity $\kappa_{1}$ ( $\mathrm{W} \mathrm{m}^{-1} \mathrm{~K}^{-1}$ ), and thickness $\Delta z_{1}(\mathrm{~m})$ is

$G_{\text {soil }}=\kappa_{1} \frac{\left(T_{\mathrm{g}}-T_{\mathrm{s} 1}\right)}{\Delta z_{1} / 2}$.
Soil temperatures are calculated from the one-dimensional energy conservation equation

$\rho c \frac{\partial T_{\mathrm{s}}}{\partial t}=\frac{\partial}{\partial z}\left(\kappa \frac{\partial T_{\mathrm{s}}}{\partial z}\right)$,

where $\rho c$ is volumetric heat capacity $\left(\mathrm{J} \mathrm{m}^{-3} \mathrm{~K}^{-1}\right)$.

\section{A7 Canopy scalars}

The calculation of air temperature $\left(T_{\mathrm{a}}\right)$, vapor pressure $\left(e_{\mathrm{a}}\right)$, and wind speed $\left(u_{\mathrm{a}}\right)$ within the canopy follows CLM4.5. With the assumption of negligible capacity to store heat in the canopy air, the total sensible heat flux exchanged with the atmosphere $(H)$ is balanced by the sum of the sensible heat flux from the ground and all canopy layers

$$
\begin{aligned}
& H=c_{p}\left(T_{\mathrm{a}}-\theta_{\mathrm{ref}}\right) g_{\mathrm{ah}}=H_{\mathrm{g}}+\sum_{i=1}^{n}\left[H_{\mathrm{sun}, i} f_{\mathrm{sun}, i}\right. \\
& \left.+H_{\text {shade }, i}\left(1-f_{\mathrm{sun}, i}\right)\right] \Delta L_{i} .
\end{aligned}
$$

Here, $H_{\text {sun }, i}$ and $H_{\text {shade, } i}$ are the leaf fluxes, given by Eq. (A4), for the sunlit leaf and shaded leaf, respectively, at canopy layer $i$. Similarly, for water vapor flux

$$
\begin{aligned}
& E=\frac{1}{P_{\text {ref }}}\left(e_{\mathrm{a}}-e_{\text {ref }}\right) g_{\mathrm{ah}}=E_{\mathrm{g}} \\
& +\sum_{i=1}^{n}\left[E_{\mathrm{sun}, i} f_{\mathrm{sun}, i}+E_{\text {shade }, i}\left(1-f_{\mathrm{sun}, i}\right)\right] \Delta L_{i},
\end{aligned}
$$

with the sunlit and shaded fluxes given by Eq. (A5). The wind speed in the canopy is

$u_{\mathrm{a}}=u_{\mathrm{ref}}\left(g_{\mathrm{am}} \hat{\rho}^{-1} / u_{\mathrm{ref}}\right)^{1 / 2}$.

Here $\theta_{\text {ref }}, e_{\text {ref }}, u_{\text {ref }}$, and $P_{\text {ref }}$ are the potential temperature $\left(\theta_{\text {ref }}=T_{\text {ref }}+0.0098 z_{\text {ref }}, \mathrm{K}\right)$, vapor pressure $(\mathrm{Pa})$, wind speed $\left(\mathrm{m} \mathrm{s}^{-1}\right)$, and pressure $(\mathrm{Pa})$ at the tower reference height, respectively. $g_{\text {am }}$ and $g_{\text {ah }}\left(\mathrm{mol} \mathrm{m}^{-2} \mathrm{~s}^{-1}\right)$ are aerodynamic conductances for momentum and heat, respectively, calculated from the Monin-Obukhov similarity theory between the tower at height $z_{\text {ref }}$ and the surface at height $z_{0}+d$. The conductance for a canopy with height $h_{\text {top }}=23 \mathrm{~m}$ (with $z_{0}=$ $0.055 h_{\text {top }}$ and $\left.d=0.67 h_{\text {top }}\right)$ and tower with height $z_{\text {ref }}=30$ $\mathrm{m}$ for neutral conditions and wind speed $u_{\mathrm{ref}}=2 \mathrm{~m} \mathrm{~s}^{-1}$ is $g_{\mathrm{am}}=2.2 \mathrm{~mol} \mathrm{~m}^{-2} \mathrm{~s}^{-1}$; this conductance increases for unstable conditions (typically during the day). The canopy air $\mathrm{CO}_{2}$ concentration is that of the tower $\left(c_{\mathrm{a}}=c_{\mathrm{ref}}\right)$. 


\section{Appendix B: List of symbols, their definition, and units}

\begin{tabular}{|c|c|}
\hline \multicolumn{2}{|c|}{ Canopy variables } \\
\hline$c_{\mathrm{a}}$ & $\mathrm{CO}_{2}$ concentration of canopy air $\left(\mu \mathrm{mol} \mathrm{mol}^{-1}\right)$ \\
\hline$d$ & Displacement height $(\mathrm{m})$ \\
\hline$e_{\mathrm{a}}$ & Vapor pressure of canopy air $(\mathrm{Pa})$ \\
\hline$g_{\text {ah }}$ & $\begin{array}{l}\text { Aerodynamic conductance for heat, above canopy } \\
\left(\mathrm{mol} \mathrm{m}^{-2} \mathrm{~s}^{-1}\right)\end{array}$ \\
\hline$g_{\mathrm{am}}$ & $\begin{array}{l}\text { Aerodynamic conductance for momentum, above } \\
\text { canopy }\left(\mathrm{mol} \mathrm{m}^{-2} \mathrm{~s}^{-1}\right)\end{array}$ \\
\hline$g_{\mathrm{ah}}^{\prime}$ & $\begin{array}{l}\text { Aerodynamic } \\
\left(\mathrm{mol} \mathrm{m}^{-2} \mathrm{~s}^{-1}\right)\end{array} \quad$ conductance, under canopy \\
\hline$K_{\mathrm{n}}$ & Canopy nitrogen decay coefficient $(-)$ \\
\hline$T_{\mathrm{a}}$ & Canopy air temperature $(\mathrm{K})$ \\
\hline$u_{\mathrm{a}}$ & Wind speed in canopy $\left(\mathrm{m} \mathrm{s}^{-1}\right)$ \\
\hline$z_{0}$ & Roughness length $(\mathrm{m})$ \\
\hline
\end{tabular}

Biometeorological variables

$c_{p} \quad$ Specific heat of air at constant pressure, $c_{p \mathrm{~d}}(1+$ $\left.0.84 q_{\mathrm{ref}}\right) M_{\mathrm{a}}\left(\mathrm{J} \mathrm{mol}^{-1} \mathrm{~K}^{-1}\right)$

$c_{p \mathrm{~d}}$ Specific heat of dry air at constant pressure $\left(1005 \mathrm{~J} \mathrm{~kg}^{-1} \mathrm{~K}^{-1}\right)$

$\gamma \quad$ Psychrometric constant, $c_{p} P_{\text {ref }} / \lambda\left(\mathrm{Pa} \mathrm{K}^{-1}\right)$

$D_{\mathrm{h}} \quad$ Thermal diffusivity of air $\left(21.5 \times 10^{-6} \mathrm{~m}^{2} \mathrm{~s}^{-1}\right.$ at $20^{\circ} \mathrm{C}$ and sea level)

$D_{\mathrm{v}} \quad$ Molecular diffusivity of $\mathrm{H}_{2} \mathrm{O}\left(24.8 \times 10^{-6} \mathrm{~m}^{2} \mathrm{~s}^{-1}\right.$ at $20^{\circ} \mathrm{C}$ and sea level)

$e_{*}(T) \quad$ Saturation vapor pressure $(\mathrm{Pa})$ at temperature $T$

$g \quad$ Gravitational acceleration $\left(9.80665 \mathrm{~m} \mathrm{~s}^{-2}\right)$

$\lambda$ Latent heat of vaporization, $56780.3-42.84 T_{\text {ref }}$ $\left(\mathrm{J} \mathrm{mol}^{-1}\right)$

$M_{\mathrm{a}} \quad$ Molecular mass of air, $\rho_{\mathrm{a}} / \hat{\rho}\left(\mathrm{kg} \mathrm{mol}^{-1}\right)$

$M_{\mathrm{d}} \quad$ Molecular mass of dry air $\left(0.02897 \mathrm{~kg} \mathrm{~mol}^{-1}\right)$

$M_{\mathrm{W}} \quad$ Molecular mass of water $\left(0.01802 \mathrm{~kg} \mathrm{~mol}^{-1}\right)$

$q_{\text {ref }} \quad$ Specific humidity, $0.622 e_{\text {ref }} /\left(P_{\text {ref }}-0.378 e_{\text {ref }}\right)$ $\left(\mathrm{kg} \mathrm{kg}^{-1}\right)$

$\Re \quad$ Universal gas constant $\left(8.31446 \mathrm{~J} \mathrm{~K}^{-1} \mathrm{~mol}^{-1}\right)$

$\hat{\rho} \quad$ Molar density, $P_{\text {ref }} / \mathfrak{R} T_{\text {ref }}\left(\mathrm{mol} \mathrm{m}^{-3}\right)$

$\rho_{\mathrm{a}} \quad$ Air density, $\hat{\rho} M_{\mathrm{d}}\left(1-0.378 e_{\text {ref }} / P_{\text {ref }}\right)\left(\mathrm{kg} \mathrm{m}^{-3}\right)$

$\rho_{\mathrm{W}} \quad$ Density of water $\left(1000 \mathrm{~kg} \mathrm{~m}^{-3}\right)$

$s \quad$ Slope of saturation vapor pressure, $d e_{*}(T) / \mathrm{d} T$ $\left(\mathrm{Pa} \mathrm{K}^{-1}\right)$

\begin{tabular}{|c|c|c|}
\hline \multicolumn{3}{|c|}{ Model variables defined at each leaf layer } \\
\hline$A_{\mathrm{c}}$ & $\begin{array}{l}\text { Leaf rubisco-limited } \\
\left(\mu \mathrm{mol} \mathrm{CO} 2 \mathrm{~m}^{-2} \mathrm{~s}^{-1}\right)\end{array}$ & assimilation \\
\hline$A_{j}$ & $\begin{array}{ll}\text { Leaf } & \text { RuBP-limited } \\
\left(\text { umol } \mathrm{CO}_{2} \mathrm{~m}^{-2} \mathrm{~s}^{-1}\right)\end{array}$ & assimilation \\
\hline$A_{\mathrm{n}}$ & \multicolumn{2}{|c|}{ Leaf net assimilation $\left(\mu \mathrm{mol} \mathrm{CO}_{2} \mathrm{~m}^{-2} \mathrm{~s}^{-1}\right)$} \\
\hline$c_{\mathrm{i}}$ & \multicolumn{2}{|c|}{ Leaf intercellular $\mathrm{CO}_{2}$ concentration $\left(\mu \mathrm{mol} \mathrm{mol}{ }^{-1}\right)$} \\
\hline$c_{\mathrm{S}}$ & \multicolumn{2}{|c|}{ Leaf surface $\mathrm{CO}_{2}$ concentration $\left(\mu \mathrm{mol} \mathrm{mol}^{-1}\right)$} \\
\hline$\Gamma_{*}$ & \multicolumn{2}{|c|}{$\mathrm{CO}_{2}$ compensation point $\left(\mu \mathrm{mol} \mathrm{mol}^{-1}\right)$} \\
\hline$D_{\mathrm{s}}$ & \multicolumn{2}{|c|}{ Vapor pressure deficit at leaf surface ( $\mathrm{Pa}$ or $\left.\mathrm{mol} \mathrm{mol}^{-1}\right)$} \\
\hline$e_{\mathrm{S}}$ & \multicolumn{2}{|c|}{ Vapor pressure at leaf surface $(\mathrm{Pa})$} \\
\hline$E_{1}$ & \multicolumn{2}{|c|}{ Leaf transpiration flux $\left(\mathrm{mol} \mathrm{H}_{2} \mathrm{Om}^{-2} \mathrm{~s}^{-1}\right)$} \\
\hline$\lambda E_{1}$ & \multicolumn{2}{|c|}{ Leaf latent heat flux $\left(\mathrm{W} \mathrm{m}^{-2}\right)$} \\
\hline$f_{\text {sun }}$ & \multicolumn{2}{|l|}{ Sunlit fraction $(-)$} \\
\hline$g_{\text {bh }}$ & $\begin{array}{l}\text { Leaf boundary } \\
\left(\mathrm{mol} \mathrm{m}^{-2} \mathrm{~s}^{-1}\right)\end{array}$ & onductance for \\
\hline
\end{tabular}

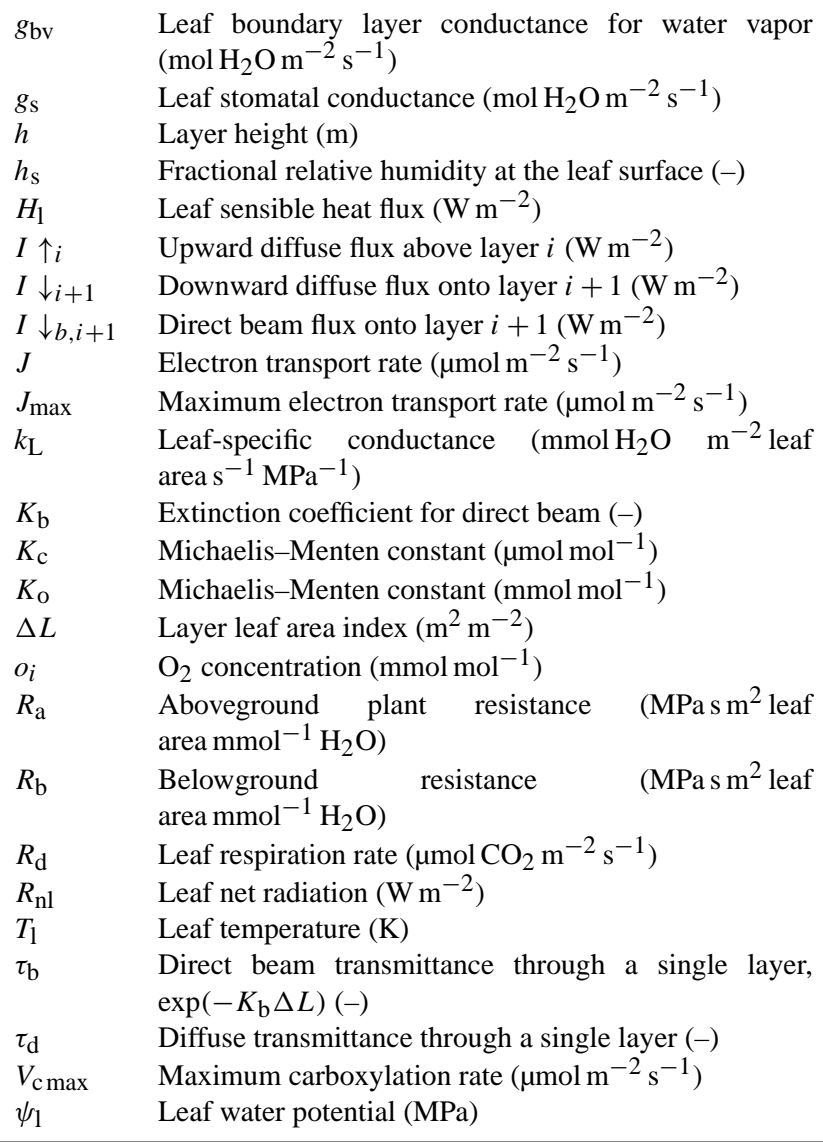

Soil variables

\begin{tabular}{|c|c|}
\hline$\lambda E_{\mathrm{g}}$ & Ground surface latent heat flux $\left(\mathrm{W} \mathrm{m}^{-2}\right)$ \\
\hline$E_{\max , j}$ & $\begin{array}{l}\text { Maximum water uptake rate for soil layer } \\
\left(\mathrm{mmol} \mathrm{H}_{2} \mathrm{O} \mathrm{m}^{-2} \text { ground area s }{ }^{-1}\right)\end{array}$ \\
\hline$\varepsilon g$ & Soil emissivity \\
\hline$\Delta f_{j}$ & Fraction of roots in soil layer $(-)$ \\
\hline$f_{\mathrm{t}, j}$ & Fraction of transpiration supplied by soil layer (-) \\
\hline$g_{\text {soil }}$ & Soil conductance for water vapor $\left(\mathrm{mol} \mathrm{H}_{2} \mathrm{O} \mathrm{m}^{-2} \mathrm{~s}^{-1}\right)$ \\
\hline$G_{j}$ & $\begin{array}{lclll}\text { Hydraulic conductivity } & \text { of } & \text { soil } & \text { layer } \\
\left(\mathrm{mmol} \mathrm{H}_{2} \mathrm{O} \mathrm{m}^{-1} \mathrm{~s}^{-1} \mathrm{MPa}^{-1}\right) & & & \end{array}$ \\
\hline$G_{\text {soil }}$ & Soil heat flux $\left(\mathrm{W} \mathrm{m}^{-2}\right)$ \\
\hline$h_{g}$ & Fractional relative humidity at the soil surface (-) \\
\hline$H_{\mathrm{g}}$ & Ground surface sensible heat flux $\left(\mathrm{W} \mathrm{m}^{-2}\right)$ \\
\hline$k_{\mathrm{r}, j}$ & $\begin{array}{l}\text { Root-to-stem conductance of soil } \\
\left(\mathrm{mmol} \mathrm{H}_{2} \mathrm{O} \mathrm{m}^{-2} \text { ground area s }{ }^{-1} \mathrm{MPa}^{-1}\right)\end{array}$ \\
\hline$k_{\mathrm{s}, j}$ & $\begin{array}{l}\text { Soil-to-root conductance of soil } \\
\left(\mathrm{mmol} \mathrm{H}_{2} \mathrm{O} \mathrm{m}^{-2} \text { ground area s}\right.\end{array}$ \\
\hline$\kappa_{j}$ & Thermal conductivity of soil layer $\left(\mathrm{W} \mathrm{m}^{-1} \mathrm{~K}^{-1}\right)$ \\
\hline$L_{\mathrm{r}, j}$ & Root length density of soil layer ( $\mathrm{m}$ root $\mathrm{m}^{-3}$ soil) \\
\hline$M_{\mathrm{r}, j}$ & Root biomass density of soil layer ( $\mathrm{g}$ biomass $\mathrm{m}^{-3}$ soil) \\
\hline$r_{\mathrm{s}, j}$ & One-half the distance between roots in soil layer $(\mathrm{m})$ \\
\hline$R_{\text {ng }}$ & Ground surface net radiation $\left(\mathrm{W} \mathrm{m}^{-2}\right)$ \\
\hline$\rho c_{j}$ & Volumetric heat capacity of soil layer $\left(\mathrm{J} \mathrm{m}^{-3} \mathrm{~K}^{-1}\right)$ \\
\hline$T_{\mathrm{g}}$ & Ground surface temperature $(\mathrm{K})$ \\
\hline$T_{\mathrm{s}, j}$ & Temperature of soil layer $(\mathrm{K})$ \\
\hline$\psi_{\mathrm{s}, j}$ & Soil water potential of layer (MPa, or m) \\
\hline $\bar{\psi}_{\mathrm{s}}$ & Weighted soil water potential (MPa) \\
\hline$\Delta z_{j}$ & Thickness of soil layer (m) \\
\hline
\end{tabular}


Acknowledgements. The National Center for Atmospheric Research is sponsored by the National Science Foundation. This work was supported by National Science Foundation grant EF-1048481 and by the National Science Foundation Science and Technology Center for Multi-Scale Modeling of Atmospheric Processes, managed by Colorado State University under cooperative agreement No. ATM-0425247.

Edited by: C. Sierra

\section{References}

Baldocchi, D. and Meyers, T.: On using eco-physiological, micrometeorological and biogeochemical theory to evaluate carbon dioxide, water vapor and trace gas fluxes over vegetation: a perspective, Agr. Forest Meteorol., 90, 1-25, 1998.

Baldocchi, D. D. and Wilson, K. B.: Modeling $\mathrm{CO}_{2}$ and water vapor exchange of a temperate broadleaved forest across hourly to decadal time scales, Ecol. Model., 142, 155-184, 2001.

Baldocchi, D. D., Wilson, K. B., and Gu, L.: How the environment, canopy structure and canopy physiological functioning influence carbon, water and energy fluxes of a temperate broadleaved deciduous forest - an assessment with the biophysical model CANOAK, Tree Physiol., 22, 1065-1077, 2002.

Ball, J. T., Woodrow, I. E., and Berry, J. A.: A model predicting stomatal conductance and its contribution to the control of photosynthesis under different environmental conditions, in: Progress in Photosynthesis Research, Vol. 4, edited by: Biggins, J., Martinus Nijhoff, the Netherlands, 221-224, 1987.

Bonan, G. B.: Land-atmosphere $\mathrm{CO}_{2}$ exchange simulated by a land surface process model coupled to an atmospheric general circulation model, J. Geophys. Res., 100D, 2817-2831, 1995.

Bonan, G. B., Lawrence, P. J., Oleson, K. W., Levis, S., Jung, M., Reichstein, M., Lawrence, D. M., and Swenson, S. C.: Improving canopy processes in the Community Land Model version 4 (CLM4) using global flux fields empirically inferred from FLUXNET data, J. Geophys. Res., 116, G02014, doi:10.1029/2010JG001593, 2011.

Bonan, G. B., Oleson, K. W., Fisher, R. A., Lasslop, G., and Reichstein, M.: Reconciling leaf physiological traits and canopy flux data: use of the TRY and FLUXNET databases in the Community Land Model version 4, J. Geophys. Res., 117, G02026, doi:10.1029/2011JG001913, 2012.

Choat, B., Jansen, S., Brodribb, T. J., Cochard, H., Delzon, S., Bhaskar, R., Bucci, S. J., Field, T. S., Gleason, S. M., Hacke, U. G., Jacobsen, A. L., Lens, F., Maherali, H., Martínez-Vilalta, J., Mayr, S., Mencuccini, M., Mitchell, P. J., Nardini, A., Pittermann, J., Pratt, R. B., Sperry, J. S., Westoby, M., Wright, I. J., and Zanne, A. E.: Global convergence in the vulnerability of forests to drought, Nature, 491, 752-755, 2012.

Collatz, G. J., Ball, J. T., Grivet, C., and Berry, J. A.: Physiological and environmental regulation of stomatal conductance, photosynthesis and transpiration: a model that includes a laminar boundary layer, Agr. Forest Meteorol., 54, 107-136, 1991.

Cowan, I. R.: Stomatal behavior and environment, Adv. Bot. Res., 4, 117-228, 1977.

Cowan, I. R. and Farquhar, G. D.: Stomatal function in relation to leaf metabolism and environment, in: Integration of Activity in the Higher Plant, edited by: Jennings, D. H., Cambridge University Press, Cambridge, 471-505, 1977.

Cox, P. M., Huntingford, C., and Harding, R. J.: A canopy conductance and photosynthesis model for use in a GCM land surface scheme, J. Hydrol., 212-213, 79-94, 1998.

De Kauwe, M. G., Medlyn, B. E., Zaehle, S., Walker, A. P., Dietze, M. C., Hickler, T., Jain, A. K., Luo, Y., Parton, W. J., Prentice, I. C., Smith, B., Thornton, P. E., Wang, S., Wang, Y.-P., Warlind, D., Weng, E., Crous, K. Y., Ellsworth, D. S., Hanson, P. J., Kim, H.-S., Warren, J. M., Oren, R., and Norby, R. J.: Forest water use and water use efficiency at elevated $\mathrm{CO}_{2}$ : a model-data intercomparison at two contrasting temperate forest FACE sites, Global Change Biol., 19, 1759-1779, 2013.

Duursma, R. A. and Medlyn, B. E.: MAESPA: a model to study interactions between water limitation, environmental drivers and vegetation function at tree and stand levels, with an example application to $\left[\mathrm{CO}_{2}\right] \times$ drought interactions, Geosci. Model Dev., 5, 919-940, doi:10.5194/gmd-5-919-2012, 2012.

Egea, G., Verhoef, A., and Vidale, P. L.: Towards an improved and more flexible representation of water stress in coupled photosynthesis-stomatal conductance models, Agr. Forest Meteorol., 151, 1370-1384, 2011.

Ewers, B. E., Oren, R., and Sperry, J. S.: Influence of nutrient versus water supply on hydraulic architecture and water balance in Pinus taeda, Plant Cell Environ., 23, 1055-1066, 2000.

Ewers, B. E., Gower, S. T., Bond-Lamberty, B., and Wang, C. K.: Effects of stand age and tree species on canopy transpiration and average stomatal conductance of boreal forests, Plant Cell Environ., 28, 660-678, 2005.

Farquhar, G. D., von Caemmerer, S., and Berry, J. A.: A biochemical model of photosynthetic $\mathrm{CO}_{2}$ assimilation in leaves of $\mathrm{C}_{3}$ species, Planta, 149, 78-90, 1980.

Federer, C. A., Vörösmarty, C., and Fekete, B.: Sensitivity of annual evaporation to soil and root properties in two models of contrasting complexity, J. Hydrometeorol., 4, 1276-1290, 2003.

Fisher, R. A., Williams, M., Lobo do Vale, R., Lola da Costa, A., and Meir, P.: Evidence from Amazonian forests is consistent with isohydric control of leaf water potential, Plant Cell Environ., 29, 151-165, 2006.

Fisher, R. A., Williams, M., Lola da Costa, A., Malhi, Y., da Costa, R. F., Almeida, S., and Meir, P.: The response of an Eastern Amazonian rain forest to drought stress: results and modelling analyses from a throughfall exclusion experiment, Global Change Biol., 13, 2361-2378, 2007.

Foken, T.: The energy balance closure problem: an overview, Ecol. Appl., 18, 1351-1367, 2008.

Friend, A. D.: PGEN: an integrated model of leaf photosynthesis, transpiration, and conductance, Ecol. Model., 77, 233-255, 1995.

Gardner, W. R.: Dynamic aspects of water availability to plants, Soil Sci., 89, 63-73, 1960.

Goldstein, G., Andrade, J. L., Meinzer, F. C., Holbrook, N. M., Cavelier, J., Jackson, P., and Celis, A.: Stem water storage and diurnal patterns of water use in tropical forest canopy trees, Plant Cell Environ., 21, 397-406, 1998.

Hendricks Franssen, H. J., Stöckli, R., Lehner, I., Rotenberg, E., and Seneviratne, S. I.: Energy balance closure of eddy-covariance data: a multisite analysis for European FLUXNET stations, Agr. Forest Meteorol., 150, 1553-1567, 2010. 
Hetherington, A. M. and Woodward, F. I.: The role of stomata in sensing and driving environmental change, Nature, 424, 901908, 2003.

Hill, T. C., Williams, M., Woodward, F. I., and Moncrieff, J. B.: Constraining ecosystem processes from tower fluxes and atmospheric profiles, Ecol. Appl., 21, 1474-1489, 2011.

Hollinger, D. Y., Goltz, S. M., Davidson, E. A., Lee, J. T., Tu, K., and Valentine, H. T.: Seasonal patterns and environmental control of carbon dioxide and water vapour exchange in an ecotonal boreal forest, Global Change Biol., 5, 891-902, 1999.

Jackson, R. B., Mooney, H. A., and Schulze, E.-D.: A global budget for fine root biomass, surface area, and nutrient contents, Proc. Natl. Acad. Sci. USA, 94, 7362-7366, 1997.

Kattge, J. and Knorr, W.: Temperature acclimation in a biochemical model of photosynthesis: a reanalysis of data from 36 species, Plant Cell Environ., 30, 1176-1190, 2007.

Kattge, J., Knorr, W., Raddatz, T., and Wirth, C.: Quantifying photosynthetic capacity and its relationship to leaf nitrogen content for global-scale terrestrial biosphere models, Global Change Biol., 15, 976-991, 2009.

Katul, G. G., Palmroth, S., and Oren, R.: Leaf stomatal responses to vapour pressure deficit under current and $\mathrm{CO}_{2}$-enriched atmosphere explained by the economics of gas exchange, Plant Cell Environ., 32, 968-979, 2009.

Katul, G., Manzoni, S., Palmroth, S. and Oren, R.: A stomatal optimization theory to describe the effects of atmospheric $\mathrm{CO}_{2}$ on leaf photosynthesis and transpiration, Ann. Bot., 105, 431-442, 2010.

Körner, C.: Leaf diffusive conductances in the major vegetation types of the globe, in: Ecophysiology of Photosynthesis, edited by: Schulze, E.-D. and Caldwell, M. M., Springer-Verlag, Berlin, 463-490, 1994.

Koven, C. D., Riley, W. J., Subin, Z. M., Tang, J. Y., Torn, M. S., Collins, W. D., Bonan, G. B., Lawrence, D. M., and Swenson, S. C.: The effect of vertically resolved soil biogeochemistry and alternate soil $\mathrm{C}$ and $\mathrm{N}$ models on C dynamics of CLM4, Biogeosciences, 10, 7109-7131, doi:10.5194/bg-10-7109-2013, 2013.

Leuning, R.: A critical appraisal of a combined stomatalphotosynthesis model for $\mathrm{C}_{3}$ plants, Plant Cell Environ., 18, 339355, 1995.

Leuning, R., van Gorsel, E., Massman, W. J., and Issac, P. R.: Reflections on the surface energy imbalance problem, Agr. Forest Meteorol., 156, 65-74, 2012.

Lloyd, J., Patiño, S., Paiva, R. Q., Nardoto, G. B., Quesada, C. A., Santos, A. J. B., Baker, T. R., Brand, W. A., Hilke, I., Gielmann, H., Raessler, M., Luizão, F. J., Martinelli, L. A., and Mercado, L. M.: Optimisation of photosynthetic carbon gain and within-canopy gradients of associated foliar traits for Amazon forest trees, Biogeosciences, 7, 1833-1859, doi:10.5194/bg-71833-2010, 2010.

Manzoni, S., Vico, G., Porporato, A., and Katul. G .: Biological constraints on water transport in the soil-plant-atmosphere system, Adv. Water Resour., 51, 292-304, 2013.

McDowell, N. G., Fisher, R. A., Xu, C., Domec, J. C., Hölttä, T., Mackay, D. S., Sperry, J. S., Boutz, A., Dickman, L., Gehres, N., Limousin, J. M., Macalady, A., Martínez-Vilalta, J., Mencuccini, M., Plaut, J. A., Ogée, J., Pangle, R. E., Rasse, D. P., Ryan, M. G., Sevanto, S., Waring, R. H., Williams, A. P., Yepez, E. A., and Pockman, W. T.: Evaluating theories of drought-induced vegeta- tion mortality using a multimodel-experiment framework, New Phytol., 200, 304-321, 2013.

Medlyn, B. E., Duursma, R. A., and Zeppel, M. J. B.: Forest productivity under climate change: a checklist for evaluating model studies, WIREs Climate Change, 2, 332-355, 2011 a.

Medlyn, B. E., Duursma, R. A., Eamus, D., Ellsworth, D. S., Prentice, I. C., Barton, C. V. M., Crous, K. Y., de Angelis, P., Freeman, M., and Wingate, L.: Reconciling the optimal and empirical approaches to modelling stomatal conductance, Global Change Biol., 17, 2134-2144, 2011b.

Meinzer, F. C.: Co-ordination of vapour and liquid phase water transport properties in plants, Plant Cell Environ., 25, 265-274, 2002.

Meinzer, F. C., Goldstein, G., Jackson, P., Holbrook, N. M., Gutiérrez, M. V., and Cavelier, J.: Environmental and physiological regulation of transpiration in tropical forest gap species: the influence of boundary layer and hydraulic properties, Oecologia, 101, 514-522, 1995.

Mencuccini, M.: The ecological significance of long-distance water transport: short-term regulation, long-term acclimation and the hydraulic costs of stature across plant life forms, Plant Cell Environ., 26, 163-182, 2003.

Newman, E. I.: Resistance to water flow in soil and plant. I. Soil resistance in relation to amounts of root: theoretical estimates, J. Appl. Ecol., 6, 1-12, 1969.

Norman, J. M.: Modeling the complete crop canopy, in: Modification of the Aerial Environment of Plants, edited by: Barfield, B. J. and Gerber, J. F., Am. Soc. of Agric. Eng., St. Joseph, Mich, 249-277, 1979.

Oleson, K. W., Lawrence, D. M., Bonan, G. B., Drewniak, B., Huang, M., Koven, C. D., Levis, S., Li, F., Riley, W. J., Subin, Z. M., Swenson, S. C., Thornton, P. E., Bozbiyik, A., Fisher, R., Heald, C. L., Kluzek, E., Lamarque, J.-F., Lawrence, P. J., Leung, L. R., Lipscomb, W., Muszala, S., Ricciuto, D. M., Sacks, W., Sun, Y., Tang, J., and Yang, Z.-L.: Technical description of version 4.5 of the Community Land Model (CLM), NCAR Tech. Note NCAR/TN-503+STR, National Center for Atmospheric Research, Boulder, Colorado, 420 pp., 2013.

Ollinger, S. V., Richardson, A. D., Martin, M. E., Hollinger, D. Y., Frolking, S. E., Reich, P. B., Plourde, L. C., Katul, G. G., Munger, J. W., Oren, R., Smith, M.-L., Paw U, K. T., Bolstad, P. V., Cook, B. D., Day, M. C., Martin, T. A., Monson, R. K., and Schmid, H. P.: Canopy nitrogen, carbon assimilation, and albedo in temperate and boreal forests: Functional relations and potential climate feedbacks, Proc. Natl. Acad. Sci. USA, 105, 19336-19341, 2008.

Oren, R., Sperry, J. S., Katul, G. G., Pataki, D. E., Ewers, B. E., Phillips, N., and Schäfer, K. V. R.: Survey and synthesis of intraand interspecific variation in stomatal sensitivity to vapour pressure deficit, Plant Cell Environ., 22, 1515-1526, 1999.

Peltoniemi, M. S., Duursma, R. A., and Medlyn, B. E.: Co-optimal distribution of leaf nitrogen and hydraulic conductance in plant canopies, Tree Physiol., 32, 510-519, 2012.

Richardson, A. D., Hollinger, D. Y., Burba, G. G., Davis, K. J., Flanagan, L. B., Katul, G. G., Munger, J. W., Ricciuto, D. M., Stoy, P. C., Suyker, A. E., Verma, S. B., and Wofsy, S. C.: A multi-site analysis of random error in tower-based measurements of carbon and energy fluxes, Agr. Forest Meteorol., 136, 1-18, 2006. 
Richardson, A. D., Aubinet, M., Barr, A. G., Hollinger, D. Y., Ibrom, A., Lasslop, G. and Reichstein, M.: Uncertainty quantification, in: Eddy Covariance: A Practical Guide to Measurement and Data Analysis, edited by: Aubinet, M., Vesala, T. and Papale, D., Springer, Dordrecht, 173-209, 2012.

Rieger, M. and Litvin, P.: Root system hydraulic conductivity in species with contrasting root anatomy, J. Exper. Bot., 50, 201209, 1999.

Saliendra, N. Z., Sperry, J. S., and Comstock, J. P.: Influence of leaf water status on stomatal response to humidity, hydraulic conductance, and soil drought in Betula occidentalis, Planta, 196, 357366, 1995.

Schaefer, K., Schwalm, C. R., Williams, C., Arain, M. A., Barr, A., Chen, J. M., Davis, K. J., Dimitrov, D., Hilton, T. W., Hollinger, D. Y., Humphreys, E., Poulter, B., Raczka, B. M., Richardson, A. D., Sahoo, A., Thornton, P., Vargas, R., Verbeeck, H., Anderson, R., Baker, I., Black, T. A., Bolstad, P., Chen, J., Curtis, P. S., Desai, A. R., Dietze, M., Dragoni, D., Gough, C., Grant, R. F., Gu, L., Jain, A., Kucharik, C., Law, B., Liu, S., Lokipitiya, E., Margolis, H. A., Matamala, R., McCaughey, J. H., Monson, R., Munger, J. W., Oechel, W., Peng, C., Price, D. T., Ricciuto, D., Riley, W. J., Roulet, N., Tian, H., Tonitto, C., Torn, M., Weng, E., and Zhou, X.: A model-data comparison of gross primary productivity: results from the North American Carbon Program site synthesis, J. Geophys. Res., 117, G03010, doi:10.1029/2012JG001960, 2012.

Schmid, H. P., Grimmond, C. S. B., Cropley, F., Offerle, B., and $\mathrm{Su}, \mathrm{H}$.-B.: Measurements of $\mathrm{CO}_{2}$ and energy fluxes over a mixed hardwood forest in the mid-western United States, Agr. Forest Meteorol., 103, 357-374, 2000.

Schmid, H. P., Su, H.-B., Vogel, C. S., and Curtis, P. S.: Ecosystematmosphere exchange of carbon dioxide over a mixed hardwood forest in northern lower Michigan, J. Geophys. Res., 108, 4417, doi:10.1029/2002JD003011, 2003.

Schwalm, C. R., Williams, C. A., Schaefer, K., Anderson, R., Arain, M. A., Baker, I., Barr, A., Black, T. A., Chen,G., Chen, J. M., Ciais, P., Davis, K. J., Desai, A., Dietze, M., Dragoni, D., Fischer, M. L., Flanagan, L. B., Grant, R., Gu, L., Hollinger, D., Izaurralde, R. C., Kucharik, C., Lafleur, P., Law, B. E., Li, L., Li, Z., Liu, S., Lokupitiya, E., Luo, Y., Ma, S., Margolis, H., Matamala, R., McCaughey, H., Monson, R. K., Oechel, W. C., Peng, C., Poulter, B., Price, D. T., Riciutto, D. M., Riley, W., Sahoo, A. K., Sprintsin, M., Sun, J., Tian, H., Tonitto, C., Verbeeck, H., and Verma, S. B.: A model-data intercomparison of $\mathrm{CO}_{2}$ exchange across North America: results from the North American Carbon Program site synthesis, J. Geophys. Res., 115, G00H05, doi:10.1029/2009JG001229, 2010.

Schwarz, P. A., Law, B. E., Williams, M., Irvine, J., Kurpius, M., and Moore, D.: Climatic versus biotic constraints on carbon and water fluxes in seasonally drought-affected ponderosa pine ecosystems, Global Biogeochem. Cy., 18, GB4007, doi:10.1029/2004GB002234, 2004.

Sellers, P. J., Randall, D. A., Collatz, G. J., Berry, J. A., Field, C. B., Dazlich, D. A., Zhang, C., Collelo, G. D., and Bounoua, L.: A revised land surface parameterization $(\mathrm{SiB} 2)$ for atmospheric GCMs, Part I: Model formulation, J. Climate, 9, 676-705, 1996.

Shimizu, M., Ishida, A., and Hogetsu, T.: Root hydraulic conductivity and whole-plant water balance in tropical saplings following a shade-to-sun transfer, Oecologia, 143, 189-197, 2005.
Siqueira, M. B., Katul, G. G., Sampson, D. A., Stoy, P. C., Juang, J.Y., McCarthy, H. R., and Oren, R: Multiscale model intercomparisons of $\mathrm{CO}_{2}$ and $\mathrm{H}_{2} \mathrm{O}$ exchange rates in a maturing southeastern US pine forest, Global Change Biol., 12, 1189-1207, 2006.

Sperry, J. S., Adler, F. R., Campbell, G. S., and Comstock, J. P.: Limitation of plant water use by rhizosphere and xylem conductance: results from a model, Plant Cell Environ., 21, 347-359, 1998.

Sperry, J. S., Hacke, U. G., Oren, R., and Comstock, J. P.: Water deficits and hydraulic limits to leaf water supply, Plant Cell Environ., 25, 251-263, 2002.

Stöckli, R., Lawrence, D. M., Niu, G.-Y., Oleson, K. W., Thornton, P. E., Yang, Z.-L., Bonan, G. B., Denning, A. S., and Running, S. W.: Use of FLUXNET in the Community Land Model development, J. Geophys. Res., 113, G01025, doi:10.1029/2007JG000562, 2008.

Stoy, P. C., Katul, G. G., Siqueira, M. B. S., Juang, J.-Y., Novick, K. A., McCarthy, H. R., Oishi, A. C., Uebelherr, J. M., Kim, H.-S., and Oren, R.: Separating the effects of climate and vegetation on evapotranspiration along a successional chronosequence in the southeastern US, Global Change Biol., 12, 2115-2135, 2006.

Stoy, P. C., Mauder, M., Foken, T., Marcolla, B., Boegh, E., Ibrom, A., Arain, M. A., Arneth, A., Aurela, M., Bernhofer, C., Cescatti, A., Dellwik, E., Duce, P., Gianelle, D., van Gorsel, E., Kiely, G., Knohl, A., Margolis, H., McCaughey, H., Merbold, L., Montagnani, L., Papale, D., Reichstein, R., Saunders, M., Serrano-Ortiz, P., Sottocornola, M., Spano, D., Vaccari, F., and Varlagin, A.: A data-driven analysis of energy balance closure across FLUXNET research sites: the role of landscape scale heterogeneity, Agr. Forest Meteorol., 171/172, 137-152, 2013.

Taylor, K. E.: Summarizing multiple aspects of model performance in a single diagram, J. Geophys. Res., 106D, 7183-7192, 2001.

Tuzet, A., Perrier, A., and Leuning, R.: A coupled model of stomatal conductance, photosynthesis and transpiration, Plant Cell Environ., 26, 1097-1116, 2003.

Thomas, C. K., Law, B. E., Irvine, J., Martin, J. G., Pettijohn, J. C., and Davis, K. J.: Seasonal hydrology explains interannual and seasonal variation in carbon and water exchange in a semiarid mature ponderosa pine forest in central Oregon, J. Geophys Res., 114, G04006, doi:10.1029/2009JG001010, 2009.

Tyree, M. T., Cochard, H., Cruiziat, P., Sinclair, B., and Ameglio, T.: Drought-induced leaf shedding in walnut: evidence for vulnerability segmentation, Plant Cell Environ., 16, 879-882, 1993.

Tyree, M. T., Yang, S., Cruiziat, P., and Sinclair, B.: Novel methods of measuring hydraulic conductivity of tree root systems and interpretation using AMAIZED: a maize-root dynamic model for water and solute transport, Plant Physiol., 104, 189-199, 1994.

Tyree, M. T., Velez, V., and Dalling, J. W.: Growth dynamics of root and shoot hydraulic conductance in seedlings of five neotropical tree species: scaling to show possible adaptation to differing light regimes, Oecologia, 114, 293-298, 1998.

Urbanski, S., Barford, C., Wofsy, S., Kucharik, C., Pyle, E., Budney, J., McKain, K., Fitzjarrald, D., Czikowsky, M., and Munger, J. W.: Factors controlling $\mathrm{CO}_{2}$ exchange on timescales from hourly to decadal at Harvard Forest, J. Geophys. Res., 112, G02020, doi:10.1029/2006JG000293, 2007.

Verhoef, A. and Egea, G.: Modeling plant transpiration under limited soil water: Comparison of different plant and soil hydraulic 
parameterizations and preliminary implications for their use in land surface models, Agr. Forest Meteorol., 191, 22-32, 2014.

Vico, G., Manzoni, S., Palmroth, S., Weih, M., and Katul, G.: A perspective on optimal leaf stomatal conductance under $\mathrm{CO}_{2}$ and light co-limitations, Agr. Forest Meteorol., 182/183, 191-199, 2013.

Williams, M., Rastetter, E. B., Fernandes, D. N., Goulden, M. L., Wofsy, S. C., Shaver, G. R., Melillo, J. M., Munger, J. W., Fan, S.-M., and Nadelhoffer, K. J.: Modelling the soil-plantatmosphere continuum in a Quercus-Acer stand at Harvard Forest: the regulation of stomatal conductance by light, nitrogen and soil/plant hydraulic properties, Plant Cell Environ., 19, 911-927, 1996.

Williams, M., Malhi, Y., Nobre, A. D., Rastetter, E. B., Grace, J., and Pereira, M. G. P.: Seasonal variation in net carbon exchange and evapotranspiration in a Brazilian rain forest: a modelling analysis, Plant Cell Environ., 21, 953-968, 1998.

Williams, M., Eugster, W., Rastetter, E. B., McFadden, J. P., and Chapin III, F. S.: The controls on net ecosystem productivity along an Arctic transect: a model comparison with flux measurements, Global Change Biol., 6, 116-126, 2000.

Williams, M., Law, B. E., Anthoni, P. M., and Unsworth, M. H.: Use of a simulation model and ecosystem flux data to examine carbon-water interactions in ponderosa pine, Tree Physiol., 21, 287-298, 2001a.
Williams, M., Bond, B. J., and Ryan, M. G.: Evaluating different soil and plant hydraulic constraints on tree function using a model and sap flow data from ponderosa pine, Plant Cell Environ., 24, 679-690, 2001b.

Wright, I. J., Reich, P. B., Westoby, M., Ackerly, D. D., Baruch, Z., Bongers, F., Cavender-Bares, J., Chapin, T., Cornelissen, J. H. C., Diemer, M., Flexas, J., Garnier, E., Groom, P. K., Gulias, J., Hikosaka, K., Lamont, B. B., Lee, T., Lee, W., Lusk, C., Midgley, J. J., Navas, M.-L., Niinemets, Ü., Oleksyn, J., Osada, N., Poorter, H., Poot, P., Prior, L., Pyankov, V. I., Roumet, C., Thomas, S. C., Tjoelker, M. G., Veneklaas, E. J., and Villar, R: The worldwide leaf economics spectrum, Nature, 428, 821-827, 2004.

Yang, S. and Tyree, M. T.: Hydraulic architecture of Acer saccharum and A. rubrum: comparison of branches to whole trees and the contribution of leaves to hydraulic resistance, J. Exper. Bot., 45, 179-186, 1994.

Zeppel, M., Macinnis-Ng, C., Palmer, A., Taylor, D., Whitley, R., Fuentes, S., Yunusa, I., Williams, M., and Eamus, D: An analysis of the sensitivity of sap flux to soil and plant variables assessed for an Australian woodland using a soil-plant-atmosphere model, Functional Plant Biol., 35, 509-520, 2008.

Zhou, S., Duursma, R. A., Medlyn, B. E., Kelly, J. W. G., and Prentice, I. C.: How should we model plant responses to drought? An analysis of stomatal and non-stomatal responses to water stress, Agr. Forest Meteorol., 182/183, 204-214, 2013. 